\title{
2006 年度春季大会記事
}

2006 年度の春季大会は，5月 20 日 (土)，21 日 (日) の両日にわたって，仙台市戦災復興記念館を会場にし て開催された。研究集会では, 計 51 件の一般研究発表 が行なわれ，活発な討論がなされた(参加者計 126 名)。
研究発表後, ホテルリッチフィールド仙台 10 階フエ ニックスに扔いて懇親会が催され，会員の親睦交流が 深まった (参加者計 63 名)。以下に研究発表の要旨を 掲載する。

\section{一般研究発表要旨}

中村元保（東北大・院）：関東自動車工業株式会社岩手工場の立地と関連産業の集積

山本健太（東北大・院）：ソウルに扔けるアニメーション産業の集積メカニズム

葛西大和（山形大）：たたら製鉄の構成要件としての砂鉄に関する統計について

初沢敏生（福島大）：陶磁器産地氾打る「伝統」に関する一考察一萩焼と宮島焼を例に一

高本 隆・黒木貴一 (福岡教育大) : 宗像市 I 社における日本酒販売と来客者の分布の GIS 分析

鈴木早百合（トーカドエナジー（株））・酒井宣昭（東北学院大・非）：衰退傾向にある白石温麺製造業の存続基盤 小泉 諒 (首都大・院)：企業戦略からみた人材派遣業の立地展開一東北地方を中心として一

山口泰史 $($ 荘銀総合研究所) ・江崎雄治（専修大）・松山 董（東北公益文科大）：山形県庄内地域出身者のU夕ー ン移動と職歴

鈴木貞夫：福島市（金谷川～東湯野）の古代道

戸祭由美夫・出田和久 (奈良女子大) ・平井松午 (徳島大) ・ 小野寺 淳 (茨城大) ・中西和子 (奈良女子大) : 盛岡 市中央公民館所蔵の幕末蝦夷地陣屋関係絵地図について

松山 薫（東北公益文科大）：「日輪兵舎」の戦後一その解体・復元・保存一

遠城明雄（九州大）：近代日本に扮ける「都市下層社会」の表象

米地文夫（ハーナムキヤ景観研究所）・木村清且（岩手県立大・院）：宮沢賢治の寓話「黒ぶだう」と花巻・菊池邸 との関係ーイーハトヴに抢ける岩手と北海道の重合の例一

多田忠義（東北大・院）：間伐施業の実態と地域林業の新展開一宮城県・石巻地区森林組合を事例として一

佐及木英憲（上越教育大・院）：過疎・高齢化に伴う燒畑集落の变容一山形県旧温海町小菅野代・峠の山・鍋倉集 落を事例として一

元木 靖 (埼玉大) : 分布論的にみた日本列島のクリと人間との関係

藤崎浩幸（弘前大）・中島大介（(株）パナホーム愛岐）・谷口 建（弘前大）：岩木山登山道のゴミ

㯟原智美（弘前大・院）・嶋村 道・牧田 擎（弘前大）：白神山地周辺地域にみられる自然資源利用の地域性

沼田尚也 (北海道大・院)・橋本雄一（北海道大）：札幌市に扔ける集合住宅の立地変化

大友康博（東北大・研）：仙台の都市・建築計画に肪ける均質空間の問題構制

山田浩久 (山形大) : 仙台市に扔ける市街地景観の変遷と景観計画の妥当性

金安岩男（慶應大）：地方自治体に扔ける政策形成の仕組みづくり

高津斌彰（新潟大）：1990 年以前と以後の地方都市再開発とその問題

杉山悠然 (北海道大・院) ・渡邊雅彦: 福島県安達太良連峰山稜部に抢ける植生景観 (2)一山頂現象と植生分布一

若松伸彦（横浜国立大・院）・池田重人（森林総合研究所）・河野樹一郎（京都府立大・院）：栗駒山のオオシラビ ソ小林分はいつ成立したのか？

乙幡康之（法政大・院）：阿武隈高地仙台平ドリーネに扔る蘚苔類の分布と生育環境

古田智弘 (東北大・院) ・後藤光亀（東北大）：丘陵地谷頭部の土層構成が降雨流出機構に及涩す影響

石田 武・田村俊和・菊地隆男（立正大）・宮下香織（立正大・院）・高村弘毅（立正大）：荒川中流部に扔ける近・ 現代洪水時の高水位変動と河床微地形変化

伊藤晶文 (鹿児島大)：鹿児島県志布志砂丘にみられるウォッシュオーバー堆積物

菊地 立 (東北学院大) ・吉田勇太（(株）日本旅行）：大学キャンパス内コナラ林に抢ける地温日変化 (序報) 
白 迎玖（東北公益文科大）・三上岳彦（首都大）：上海に招ける夏季ヒートアイランドと海風の影響

加藤洋祐（東北大・院）：日本における近年の黄砂観測日数変動とその総観場

佐藤賢一 (東北大・院)：寒冷前線通過時に東北地方の地形が前線に与える影響

境田清隆（東北大）・渡辺一弘（NECソフト）：仙台市におけるソメイヨシノの開花日と気温の関係

吉川契子（静岡県立静岡中央高）：静岡平野の海陸風を題材とした高等学校における課題研究の指導方法

漆原和子（法政大）：西南日本における屋敷囲いとしての石垣の分布と様式について

水本匡起（東北大・研）：横手盆地・北上低地帯の活断層と完新世の活動時期

黒木貴一 (福岡教育大) ・磯 望 (西南学院大) ・後藤健介（長崎大）・高本 隆：踏査による福岡県西方沖地震の 被害実態図作成

高見昌志 (福岡教育大・院)・黒木貴一・石黒正紀（福岡教育大）：九州における河川の水質と地理的要素との関連 清野 茂・小山孝昭・牧 滋・佐藤 勤・嵯峨京時（宮城県保健環境センター）・大庭和彦（宮城県栗原保健福祉 事務所）・藤巻宏和（東北大）：宮城県北西部鉛川の湧水と水質特性

豊島正幸（岩手県立大）・伊藤 駿 (JA 岩手県信連)：岩手山麓地帯の不圧地下水に打る硝酸性窒素濃度の分布 と季節変化

木村和雄（沖縄工業高專）：沖縄島中北部，辺野古付近のリニアメント

小元久仁夫 (日本大) ・紺野善崇 (日本大・院) : 沖縄県古宇利島および屋我地島から採取したビーチロックの ${ }^{14} \mathrm{C}$ 年代と安定同位体比

吉木岳哉 (岩手県立大) ・吉田明弘（東北大・院）：岩手山麓春子谷地湿原と周辺における晚水期以降のテフラ層序 と地形形成

檜垣大助（弘前大）・小原褰子（(独）土木研究所）：秋田県南部の珪質泥岩地すべり地における微地形と移動体内 部構造

田村俊和 (立正大) ・大久保 悟 (東京大) ・原科幸爾 (岩手大) - 中川雄助（東京大・院）・武内和彦（東京大）・

Chay ASDAK (パジャジャラン大)：西ジャワ，バンドゥン盆地南西縁の丘陵地を構成する地形類 型

阿子島 功 (山形大) : ペルー，ナスカ台地の地上絵と微地形

大月義徳（東北大）・西城 潔 (宮城教育大) ・谷口多聞（東北大・院）・中村美里（宮城教育大・院）：中国内モン

ゴル自治区武川県における農地のガリー浸食－2003 年からの観測結果を中心に一

小松原 㻟（産業技術総合研究所）：新潟県川口町で行った中越震災調査結果報告会

赤桐毅一（(株）きもと）：郡山における河川変遷と土地利用の変化

今野修平 (国土計画協会) :「地域」の検討課題

\section{関東自動車工業株式会社岩手工場の立地と関連産業の集積}

\section{中 村 元 保 (東北大・院)}

東北地方の製造業は 1980 年代に電気機械器具製造 業を中心として集積量を大きく高めたが，1990 年代に は長期の景気低迷, および工場の海外移転などにより， 全国動向と同様に不振を続けてきた。そのなかにあっ て岩手県では，自動車及び同部品製造業が工業全体に 占める比率を大きく増大させた。それは，トヨ夕自動 車の子会社である関東自動車工業（株）が岩手県央に 位置する金ヶ崎町に 1993 年に東北地方初の自動車組 立一貫工場である岩手工場を配置したことによる。ま た，岩手県や他の東北各県では，自動車産業の集積に 向けた積極的な支援を行っている。本報告は，当地域 に扔ける自動車産業の集積の経緯と状況について調 査，検討したものである。
2005 年 $4,10,11$ 月に岩手工場及びその周辺地域に 立地する岩手工場の 1 次サプライヤー15 工場を対象 にアンケート及び聞き取り調査を行った。調查内容は, 関東自動車工業（株）が金ヶ崎町に進出した経緯と生 産システム，及び金ヶ崎町周辺に集積した関連産業と の取引関係に関したものであった。

岩手工場が金ヶ崎に立地した経緯は，トヨタ社の意 向に基づいて新工場建設が決定したことに始まる。そ の立地先として, 土地の得やすさ, 交通の便の良さ, 良 質な人材の得やすさに加え, 地元の勧誘があったこと が決め手となり，金ヶ崎町の岩手中部工業団地が選択 された。岩手工場で使用する部品の大半は，トヨ夕社 あるいは関東自動車工業本社が発注する中京地区以西 
の部品メーカーから船などを用いて調達している。完 成車は，多くが仙台港を経由し中京地区に輸送されて いる。しかし，東北地方からの部品調達率は新しい車 種が生産されるとともに上昇しており，車種によって は 40\% 程度になっている。

現在岩手工場周辺に集積している工場の多くが車体 部品を生産している。車体部品の工場は自動車部品の 中でも労働集約的であるため, 用地と労働力が確保で きれば既存集積地から容易に移動できること，また嵩 張るため輸送コストが大きい製品であることから岩手 工場立地に伴い進出してきた。これらの工場に加えて, 岩手工場操業前から立地していた工場の中に，現在岩 手工場の1次サプライヤーになっているものも認めら
れる。なお，関連工場の多くは製品開発機能を持って おらず，生産機能に特化している。ただし，一部の生 産子会社の工場には取引機能がそなわり, 関東自動車 工業と直接取引を行っている。

現在，岩手工場の生産増強が進められ，また車種変 更により地元調達率が上昇している。そのため, 関連 企業のさらなる進出が期待される。また，現状におけ る地元企業の技術力は進出工場の受け皿として不十分 であるが，進出企業の増加に伴い増える参入機会に加 え，進出企業及び自治体，産官学ネットワークによる 支援により，地元企業の技術向上は今後進むと見られ る。このように，岩手工場を中心とした自動車産業集 積は，これからの発展が期待される。

\section{ソウルにおけるアニメーション産業の集積メカニズム}

\section{山本 健 太（東北大・院）}

\section{Kenta YAMAMOTO: Agglomeration of Animation Industry in Seoul}

コンテンツ産業は大都市集積を特徴にしながら，生 産工程では国際分業が進展している。従来の研究は発 注元都市に形成される産業構造に注目し, 分業先都市 に形成される産業構造については十分な言及がされて いない。そこで，本報告の目的は，ひとつには，企業 間取引の特徵から大都市におけるコンテンツ産業の集 積メカニズムについて考察することにあるが，いまひ とつには, 分業先都市に形成される産業構造の特徵を 明らかにすることにある。本報告で対象とするのは, 韓 国ソウル特別市に立地するアニメーション制作企業で ある。その理由は，アニメーション産業がわが国を代 表するコンテンツ産業のひとつであり，比較的早い時 期から日本韓国間で国際分業が進展しているためであ る。調査方法はアンケートおよび聞き取りである。 その結果, 次の諸点が明らかになった。

(1) 韓国アニメーション産業は海外市場依存型の輸 出産業である。主要な取引国は日本とアメリカである。

(2) 制作企業の規模は中小零細が一般的である。制 作企業は取引国により, 日本型企業と欧米型企業に類 型化できる。類型別の取引業界では，日本型企業の場 合, 業界内取引が一般的である。欧米型企業の場合, 周 辺産業との取引機会が相対的に多い。

(3) 企業の設立年代は類型によって異なる。日本型 企業は 1990 年代前半以前に多く，欧米型企業は 1990 年代後半以降に多い。初期の集積は日本型企業を中心 として冠岳区新林洞周辺に形成された。江南区新沙洞
周辺の集積は当該地区の CBD としての発展に伴って 1990 年代に欧米型企業を中心として形成された。

(4) 分業先都市に形成される産業構造は, 取引国の 違いによって，異なった構造が並存している。立地に ついて，日本型企業の場合，柔軟性を求めて同業他社 が多く立地し，仁川空港へのアクセスに優れる冠岳区 新林洞周辺に集積をする。欧米型企業の場合，市場情 報の入手容易性や場所の声望も考慮され, 江南区新沙 洞周辺に集積する。また, 取引構造について, 日本型 の産業構造ではスケジュールが組みにくく, 責任の所 在が不明瞭である。そのため，取引においても契約内 容の非明文化による柔軟性が重視される。欧米型の場 合，スケジュール管理が不可欠であり，責任の所在を 明確にする。そのため，取引に扔いて明文化を行う必 要がある。

次に，アニメーション制作企業の企業間取引の側面 から、ソウルにおける集積のメカニズムを考察する。集 積の行為主体は (1) 制作企業, (2) 労働市場, (3) 海外 取引先企業, (4) 国内周辺産業である。コンテンツ製品 の発信には必ず何れかの媒体が必要となる。アニメー ション産業の場合, 市場規模の最も大きいテレビ放送 がその主要な媒体と言ってよい。テレビ放送局を中心 に，周辺産業は海外市場から製品を輸入し，国内に発 信する。発信された製品は国土の全域で消費される。韓 国テレビ市場で発信される製品は日本，アメリカを中 心とした海外製品が多い。しかし，2003 年にテレビ放 
送総量制が実施された。これにより地上波放送におけ る国産アニメーション放送時間枠の設置義務付けがさ れた。海外市場に依存し，海外企業との取引を意識す ることでソウルに集積をしてきた韓国アニメーション
産業は，国内市場の拡大に伴って，スポンサー抢よび クライアントとなりえる企業本社が集中するソウルに いっそう集積を示すことになると考えられる。

\section{たたら製鉄の構成要件としての砂鉄に関する統計について}

本研究は，和式製鉄法として知られる，砂鉄を原料 として銑（ずく）や鋼（はがね）を湧出させる「たた ら式製鉄法」において使用される「小鉄」(こがね）の 採取数量を記録している史料と統計について，検討す ることを目的としている。

周知の如く,たたら製鉄においては, 原料として, 砂 鉄（山砂鉄・川砂鉄・浜砂鉄）と炭 (大炭) と粘土（「炉」 用）を不可欠とする。「小鉄七里に炭三里」という言い 伝えは，銑や鋼の生産にとっては，砂鉄と炭の確保が 生命線であることを表現している。鍛冶屋において,鉄 (「鍊鉄」) を製造する過程で使用される炭（「小炭」）を 含めて, 以上の原料の確保と入手は，たたら経営者で ある「鉄山師」にとっては，専門的技術者集団（「山内 衆」) の維持と管理とともに，経営を成立させる上で, 最も重要な課題であった。

砂鉄の採取は，炉の打ち込まれた，たたら場周辺の 農民（「地下衆」）の透間稼ぎとして，つまり，農閑期 の副業として，秋の彼岸から翌春の彼岸の頃まで，行 われる。砂鉄採取の場を「鉄穴」(かんな)，採取作業 を「鉄穴流し」という。鉄穴は，採取の場所によって， 山口，落場，川口と呼称されている。鉄穴流しのため には，鉄穴の上に，水源（「溜池」），下に，水路（「濁 水路」・「清水井手」）と，砂鉄の採取場（「砂溜」・「精 洗場」) を設置し，村方や個人に，土地の使用料を支払 わなければならない。

鉄穴流しは，鉱区を単位として行われるので，砂鉄 採取量の取調べの単位は，鉱物の国有化が法的に確認 された明治 5 年（「太政官第百号達」）以前から，鉄穴 ごとに行われた。鉱物の国有化により，鉱山の開発者 は，鉱区を借用するという形式に改められたので，「借 区坑業明細表」の提出を義務づけられた。明治 5 年の

\section{暮 西 大 和（山形大）}

雛形を元にして, 明治 6 年（工部省第十七号達）に, 「借区坑業明細表」の雛形が確定する。明治 13 年（工 部省第六号布達)には, 砂鉱区についての取調べは,「砂 鉄採取行業明細表」によることに変更され, 明治 26 年 には,「砂鉱採取法」(法律第十号)の成立を受けて,「砂 鉱採取法施行規則」(農商務省令第八号) に上り，「砂 鉄採取行業明細表」の雛形が改正されている。明治 26 年の「砂鉄採取行業明細表」では, 許可番号の他, 採 取場の位置，採取人氏名，許可年月日，坪数，越高・ 採取高・販売高 $($ 数量・代価) ・残高 $\cdot$ 工数・人員, に ついての調査が実施されている。

しかるに，鉄穴流しの集中地域であった中国山地の 個別鉄穴の砂鉄採取高を記録している唯一の官庁資料 である『大阪鉱山監督署管内鉱区一覧』は，明治 43 年 以降の統計を残しているにすぎない。『府県統計書』の 「鉱業欄」,『農商務統計表』と『帝国統計年鑑』の「鉱 業」に関する記載も，稼業砂鉱区と休業砂鉱区の数と， 府県別の砂鉄採取高を記録しているが，個々の鉄穴の 統計を欠いている。

したがって，鉄穴ごとの実態を明らかにするために は，旧鉄山師の文書か，「地方文書」に依拠せざるを得 ない状況にある。ところで，近年，島根県と鳥取県に おいて，旧鉄山師所蔵文書の整理が進展したので，鳥 取県の場合は，日野郡根雨の旧鉄山師であった近藤家 が所有した鉄山に関係する鉄穴についての実態が明ら かになりつつある。また，日野郡管内の鉄穴の砂鉄採 取高は，「鉄穴口及(小鉄取高) 取調帳」にも記録され ている。この「地方文書」を，鉱山掛が，明治 9 年に 編纂した砂鉄（流砂鉱）の採取場（採業願場）に関す る『盟約歩分根帳』と対比することにより，文久年間 以降の鉄穴流し権利者の移動を推測できる。

\section{陶磁器業における「伝統」に関する一考察一萩焼と宮島焼を例に一}

\section{初沢敏 生 (福島大)}

陶磁器業に関する従来の研究から, 各産地において についての解釈が各産地において大きく異なることが 伝統の継承が様々な形をとっていること,また,「伝統」 
史的与件ではなく，その「解釈」は現在の生産構造に も大きな影響を与えている。本報告では山口県の萩焼 と広島県の宮島焼を例に，「伝統」がぞのようにとらえ られているのかを検討した。

萩焼においては，「伝統」のとらえ方は各窨元によっ て大きく異なる。戦前から続く窐元は伝統的な原料と 生産方法を維持し，茶陶を中心とした生産を維持して いこうとしている。これに対し，数的には多数派の新 興の镱元は，そのような「伝統」に留意しつつも，必 ずしもそれにこだわらず，独自の作品を生み出すこと に力を注いでいる。この傾向が「作家を中心とする産 地」をつくりだし，産地の特性を見えにくくしている と言える。萩産地に扔いては，筀元のタイプにより「伝
統」のとらえ方が異なり，それが生産構造にも影響を 与えている。

一方，宮島焼は現在では原料も技術も変化し，かつ ての宮島焼とは連続性がなくなっている。しかし，そ のような技術的連続性ではなく，厳島神社の御神砂を 用いた焼き物を焼くことが，その「伝統的」正当性の 付与に大きな役割を果たしている。

このように,「伝統」の解釈は産地・嘿元の生産構造 や産地特性にも大きな影響を与えている。産地の生産 構造や産地振興を検討するにあたっては，その産地に おいて「伝統」が持つ意味についても検討を加えるこ とが必要である。

\section{宗像市 $\mathbb{I}$ 社の日本酒販売と来客者の分布の GIS 分析}

\section{高本隆・黒木 貴一（福岡教育大）}

Takashi TAKAMOTO and Takahito KUROKI : GIS Analyses of the Distributions on Customers and Sake Selling of Company I in Munakata City

近年，日本酒の消費が減少傾向にあることは明らか である。宗像市の造り酒屋 I 社を例に調査した結果, $\mathrm{H} 16$ 年に抢いて販売の増加が見られた。この現象を地 理的に捉えるために販売と来客者の分布を GIS を用 いて明らかにした。

取引店別の販売量を瓶別・種類別に分け，四季ごと (春： 3 月 5 月, 夏： 6 月 8 月, 秋: 9 月〜 11 月, 冬： 12 月〜2月）の point shapefile を作り，各 fileより検 索半径 $3,500 \mathrm{~m}$ で $1 \mathrm{~km}^{2}$ 当厄りのカーネル密度を計算 し， $200 \mathrm{~m}$ grid で表現した。同㥞に来客者住所情報を アドレスマッチングし来客者 point shape file を作成 した。販売量 grid file から過去の販売量 grid file を減 算した結果, $\mathrm{H} 12$ 年には 1.81 , 普通酒の販売では福岡 市，北九州市周辺の冬のピークが目立つようになり， $720 \mathrm{ml}, 300 \mathrm{ml}$, 本醸造, 吟醸酒において, 春と夏と冬 にピークが見られる。宗像市, 三㵔町では酒類や瓶種 の違いにより特定の季節に販売の増加が見られる。全 体的な日本酒販売量は福岡市，北九州市周辺，三渚地 域で増加し, 前原市周辺で減少傾向である。宗像市で は酒類や瓶種ごとに季節によって増加したり，減少し たりしていることが分かる。次に H17 年の来客者 grid file から過去の来客者 grid file を減算し, 来客者の地 域変化を捉える $\left(\right.$ 人 $\left./ \mathrm{km}^{2}\right)$ 。 $\mathrm{H} 17$ 年度から $\mathrm{H} 11$ 年度の 来客者密度を減算すると, 宗像市と北九州市, 新宮町, 福岡市東区，古賀市などの国道三号線沿いや，JR 駅，
鹿児島本線沿線の太宰府付近まで，日豊本線沿線の豊 前市付近まで，筑豊本線沿線の田川付近まで増加の広 がりがある。宗像市の東では遠賀町, 鞍手町, 宮田町 が減少し，西では福津市の東福間と津屋崎に減少があ る。福岡市では増減の差があまり見られない。筑後地 域に飛び地している。H14 年度を減算すると, H17 年 度は岡垣町より東の地域と中間市より南の地域に新規 来客者の増加があることがわかる。

次に福岡県における日本酒の消費量を見るために酒 の種類別消費量 (S47, S52, S57, S62, H7, H12, H15) を清酒，その他（焼酎，ビール類（発泡酒を含む）合 成酒・果実酒・ウイスキー・ブランデー・リキュール) に区分した。各税務署管内で区分されている酒類別消 費量を管内の面積で割り，管内面積 $\left(1 \mathrm{~km}^{2}\right.$ あたり)の 消費量 $\left(1 / \mathrm{km}^{2}\right)$ を表す。次に（株）醸界夕イムス社出 版部 (1977, 1983, 1987, 1994, 1998, 2003) から製成数 量と造り酒屋の住所を得た。その住所をアドレスマッ チングし, point shape file1 を作成し, 分割域 $\left(1 \mathrm{~km}^{2}\right.$ あたり)の製成数量 $\left(1 / \mathrm{km}^{2}\right)$ を表したボロノイ図を作 成した。S52 年に関し日本酒消費量から製成数量を減 じた結果，消費の多い地域は福岡県西部，福岡市，宗 像市から北九州市の玄海灘沿岸，大川市から大牟田市 の有明海沿岸などにある。同様に H14 年では福岡市, 北九州市，大川市などにあり，製成数量と消費量との 差が離れている地域が拡大したように見える。そこで 
$\mathrm{H} 12$ 年の結果から $\mathrm{S} 52$ 年の結果を減算し, 消費量と製 成数量と関係を見てみると日本酒がより消費されるよ うに変化しつつある地域が抽出できた。その地域は日 本酒消費増加大地域の $\mathrm{A}$ 地域 (北九州市小倉北区，戸 畑区)，B 地域(福岡市，春日市，大野城市，那珂川町), $\mathrm{C}$ 地域 (久留米市, 三㵔町) 周辺であり，消費量増加小
地域の D 地域（遠賀郡あたり）， E 地域（京都郡あた り), F 地域(福岡県西部)， G 地域(朝倉郡あたり)， $\mathrm{H}$ 地域(八女郡あたり)である。またこれらの地域と I 社 に打ける販売増加地域，来客者増加地域はマッチする ことが分かった。

\section{衰退傾向にある白石温麺製造業の存続基盤}

\section{鈴木早百合 (トーカドエナジー (株) ) ・酒井 宣昭（東北学院大・非）}

近年, 多くの地場産業産地では後継者不足, 需要減 退，市場の縮小などの問題を抱え，産地存続が厳しい 状況にある。白石温湎産地は, 70 年代から 80 年代後半 にかけて温麺ブームがあったが,ブームが去った 90 年 代以降は生産額が減少の一途を辿り,さらに近年は事 業所の倒産も2 軒あった。本報告では，このような状 況下において産地の存続基盤である技術伝承，原料の 入手形態,市場がどうなっているのかを検討した。デー 夕は, 2005 年 8 9 月に白石温麺を製造する全 11 業者 への聞き取り調査を行い, 約 $73 \%$ にあたる 8 軒の事業 所 157 (男 73, 女 84) 名から得られた結果を利用する。 白石温麺製造業は, 自社で製造から販売までを行う一 方で，製造に関して下請も持つ形態 (1 系列 3 軒，以下 (1) 形態) と, 自社で製造から販売まで一貫して行う形 態 (8 軒, 以下 (2) 形態) とがある。(1) 形態は少品種大 量生産を, (2) 形態は多品種少量生産を目指す事業所で あり，各形態によって生産販売体制や原料の入手形態 は異なる。そのため分析は形態毎に行った。

白石温麺は機械製法が主であるが，粉を練る工程や 乾燥工程などには熟練の職人技が必要とされる。当産 地には公の技術伝承機関が存在せず，両形態とも各事 業所単位で技術を伝承している。ここでは技術習得先 を，親から技術を習得した場合は「家」，就職先で技術 を習得した場合は「会社」に大別すると，各事業所の 事業主は「家」で技術を習得した子が継ぎ，その事業 主や熟練の職人が若手の職人を「会社」で育成するシ ステムになっている。したがって，技術習得先として 最も多いのは「会社」で，次いで「家」になっている。 職人の 10 歳階級別年齢構成は, (1) 形態に関しては データが得られなかったため，分析できないが，(2)形 態では 10〜70 代まで全体的に分布しているが，特に 40 59 歳にかけて多く分布し, 全体の 5 割弱を占め る。一方, 若年層の職人も育成されているため, 後継 者難の問題は現段階ではそれほど大きくないが, 温麺 業界は厳しい現況にあるため，今後の対応が課題にな
ると考えられる。

白石温麺の主原料は小麦, 塩, 水である。小麦と塩 は, (1) 形態では元請が一括購入したものを下請へ配布 し，(2)形態では事業所単位で入手している。水は両形 態とも各事業所が水道水をろ過して使用している。原 料は両形態とも一般的な外国産小麦やなみ塩を入手す るが, (2) 形態の一部の事業所では他事業所の製品との 差別化を図るため, 少量の国産小麦や天日干し塩など も入手している。現段階では，原料の入手に関して価 格高騰や入手難などの問題はみられず, 安定的に確保 できている。

主力製品は, 両形態とも機械製法による伝統的な白 い温麺であるが,近年は (2) 形態において原料に野菜な どの食材を混ぜた製品も開発されている。製品は, 贈 答用，家庭用，業務用に大別できるが，売上量の多い 製品は, (1) 形態が家庭用, (2) 形態では規模の大きい事 業所が家庭用，規模の小さい事業所が贈答用となって いる。需要の多い価格帯は, 両形態とも家庭用が 1 袋 100 円前後，贈答用が 1 箱 2,000 ～3,000 円である。

市場は,かつてから (1) 形態では系列単位で, (2) 形態 では事業所単位で確保している。温麺ブーム時は，需 要増に伴い関東圏まで市場が拡大したが，ブーム後は 需要減と市場の縮小が続き, 関東圏との取引も著しく 縮小し，近年はさらにその傾向が強まっている。販路 は, 問屋, 小売店, 飲食店, 直売, 物産展での販売に 大別できるが，(1)形態では問屋と直売の 2 経路を扱 い, この内, 問屋を重点経路としている。(2)形態では, ほとんどの事業所が問屋, 小売店, 直売の 3 経路を扱っ ているが，重点経路は規模の大きい事業所が問屋，規 模の小さい事業所が小売店か直売のどちらかである。 近年は (2) 形態の 3 軒の事業所が自社の飲食店を白石 市内に設けているが，店舗の維持費や人件費がかかる ため，生産額を増加させるほどの勢いにはなっていな い。全体的には問屋との取引が重点経路に位置づけら れるが，その問屋は県内を中心とする隣県のスーパー 
マーケットで，主に家庭用や贈答用としての取引が行 われている。取引する問屋数や取引回数, 取引量は, (2) 形態よりも (1) 形態の方が圧倒的に多い。

当産地では，技術伝承と後継者育成，原料の入手に 関しては大きな問題はみられないが, 市場の弱体化は
進んでいる。この点については, 産地の抱える問題点 での調査でも多くの事業所が指摘しているので，個々 の事業所だけでなく組合や行政も含めて早急に検討す べき課題であると考える。

\section{企業戦略からみた人材派遣業の立地展開一東北地方を中心として一}

\section{小泉諒（首都大・院）}

バブル経済崩壊後の雇用情勢の変化に伴い，多くの 企業は人件費削減のために非正規雇用者を大幅に増加 させてきたが，その過程で台頭してきたのが人材ビジ ネスである。人材派遣業や人材紹介業，再就職支援業 などで構成される人材ビジネスの中でも，とりわけ人 材派遣業の成長が著しい。人材派遣業は，1982 年の労 働者派遣法制定とともに誕生した業種で，派遣可能な 業務や期間など，労働者保護の立場から規制を受けて きた。しかし，1999 年の法改正により，派遣可能業務 は，一部の禁止業務を除いて大幅に拡大され，2004 年 の改正では製造業務への派遣も解禁された。これは,事 務職を主体としていた派遣先を変化させ，人材派遣業 の立地にも影響を与えると考えられる。

人材派遣業に関する数少ない地理学研究である友 澤・石丸（2004），石丸・友澤（2006）は，人材派遣業 が東京をはじめとする三大都市圏への集中が顕著で, 広域中心都市への立地も進んでいること，また都市内 では派遣先企業と登録者を集めるために，都心部への 集中がみられることなどが明らかにされている。しか しながら，人材派遣業に関する各種統計資料が未整備 なこともあり，2004 年の法改正による影響は検討され ておらず，企業間・地域間での立地の差異も十分に明 らかになっていない。

そこで本研究は,東北地方を主たる対象としながら， 大手事業者を中心にした人材派遣業の立地展開につい て，市場の特性や企業戦略の違いをふまえて検討する ことを目的とする。そのために，大手派遣事業者 5 社 へ聞き取り調査を行い, 国勢調査ならびに事業所・企 業統計調査，東北地方各県の労働局より提供された資 料と合わせて分析を行った。

その結果，以下のことがらが明らかとなった。 大手事業者の立地展開には，支店の運営方式と事業
子会社の有無によって，企業間に差がみられる。支店 の運営を直営で行う場合，事業方針やブランドイメー ジの統一が容易である。これに対して，フランチャイ ズ方式の場合，提携先である地元有力企業の持つ知名 度や情報などの基盤を括用できる利点がある。一方, 事 業子会社を設けている場合，特定分野に特化した人材 を募集・派遣することで，派遣先企業に対し専門性で アピールできるのに対し，設けていない場合は，受注 空口を一本化することでワンストップ・アクセスを実 現し，派遣先に分かりやすい体制となる。

事例として取り上げた，東北地方における大手事業 者の立地展開の分析から，前述した企業間の差が少な からず影響を及ぼしていることが判明した。たとえば， フランチャイズ方式による展開を進めた B 社系列の B1 社は, 東北地方において他社に先駆けて主要都市へ 進出した。一方，事業子会社を設けていない後発のE 社は, 2004 年に解禁された製造業務への派遣に積極的 に取り組むため，他社が進出していない北上市や大崎 市（旧古川市）へ立地展開を進めている。

大手 5 社が早期に立地した仙台市内では，全国企業 の支所の事務職需要を見込んで立地展開が進められ た。同市の支店経済という特徵を反映して, 本社の意 向による支店規模の縮小やコスト削減圧力の高まるな か, 全国企業は派遣労働者の活用を積極的に進めてい る。しかし，仙台市の支店は従業員規模が大きくない ため，人材派遣の一契約当たりの人数も小さい。また， 人事権が本社に集約化され，支店への労働者派遣契約 が本社で締結されるケースも増えており，全国展開し ていない派遣会社は受注困難な状態にある。大手派遣 業者は,いずれも顧客と労働者のアクセスを重視して, 事業所を都心部のランドマークとなるインテリジェン トビルに立地させている。 


\section{山形県庄内地域出身者の U ターン移動と職歴}

\section{山口 泰史（荘銀総研）・江崎 雄治（專修大）・松山 薰（東北公益文科大）}

\section{1.はじめに}

山形県では現在，人口の社会減少に加えて自然減少 も進行している。したがって，地域の活力を維持，増 進するためには，U ターンなど人口流入の促進が必要 と考えられる。

演者らはこれまで,山形県庄内地域出身者の U夕ー ンについて,いくつかの観点から議論を行ってきたが, 本研究では，これまで研究蓄積の少なかった，域外て 一度就職してからUターンした人の職歴について分 析を行った。

なお，調查の概要については江崎ほか（2005，平成 17 年度日本地理学会春季学術大会発表要旨集) を参照 されたい。

\section{2. 分析結果}

（1）Uターンするまでの平均転職回数

学歴・性別・世代間（1976～78 年高校卒，1986～88 年高校卒, 1996 98 年高校卒)で大きな違いはなく, 全 体の平均も0.29 回と極めて少ない。

(2) U夕ーン時点での職の有無

男性は，世代が若くなるほぞUターン時点で職を得 ていない割合が高い。女性は男性よりさらにその割合 が高い（女性の場合は既婚者の随伴移動も考えられる が，Uターン者の大半は未婚であった)。また，Uター ン後に次の仕事に就くまでの平均期間は女性の方が長 いが，男女とも若い世代ほど短くなっている。

(3) U ターン前後での雇用形態の変化

転職者では，1976〜 78 年高校卒では「会社員から会 社員」が過半数であったが，不況の影響から女性では 「会社員からアルバイト・パート」も多い。また，男性 には親の跡を継ぐなど自営業に転身する人も多い。一 方，1986〜88 年高校卒では「会社員から会社員」の割 合は低下しているが，バブル景気の影響から，「公務 員・教員から会社員」（主に男性）「アルバイト・パー 卜から会社員」（主に女性）も多く見られる。
（4）「会社員から会社員」の職種の変化

1976 78 年高校卒も 1986 88 年高校卒も，U 夕ー ン後の職種は「事務。管理職」（主に高卒女性），「技術 職」(主に男性および進学女性) が多い。また，U夕ー ン前後で同じ職種に就いた人は，両世代とも 6 割前後 である。ただし，1976〜 78 年高校卒では，Uターン後 に「土場労務・建設作業・交通運転職」に就いた人も 多い（主に高卒男性）。

（5）Uターンによる企業規模の変化

「会社員から会社員」への転職者の場合，世代に共 通して企業規模は小さくなる。ただし，男性より女性， 高卒者より進学者で，その割合は若干低い。

（6）転職の手段

会社員に転職した人にとって最も役立った手段は， 1976 78 年高校卒では「家族・知人などの紹介」が最 も多く,次いで職安などの求人情報」であったが, 1996 ～98 年高校卒では両者は逆転している。ただし，進学 者より高卒者，男性より女性で職安などの求人情報」 の割合が若干高い。

3. 考察とまとめ

他地域で就業経験のあるU ターン者は, ほとんど転 職を経験していない。つまり，Uターンすることが転 職の契機といえる。

また，男性より女性の方が，Uターンしてから職探 しを始めるケースが多い。これは，女性の転職環境の 厳しさと同時に, 周囲も含めた男性との就労意識の違 いも影響していると考えられる。

一方, 転職 Uターンの場合, 雇用形態や職種は景気 に左右されるが,いずれにせよ企業規模は小さくなる。

さらに，近年は転職の手段として，職安などの情報 が頼りとなっており，人脈による就職には限界が生じ ている。Uターン率が停滞・低下傾向にあるのはその ことも一因と考えられる。

\section{福島市（金谷川～東湯野）の古代道}

奈良時代には，東山道が福島盆地を直線的に通過し た。その調査は地籍図と観察に頼った。その道は金谷 川駅から北に $300 \mathrm{~m}$ 北進すると旧地名が直道の福島

\section{鈴 木 貞 夫}

大学構内になる。その北西から旧浅川村と関谷村の界 を北西に丘陵を行くと平田になり，その平坦面を北北 東に $1.5 \mathrm{~km}$ を字吉次森などの字界行くと幅の広い曲 


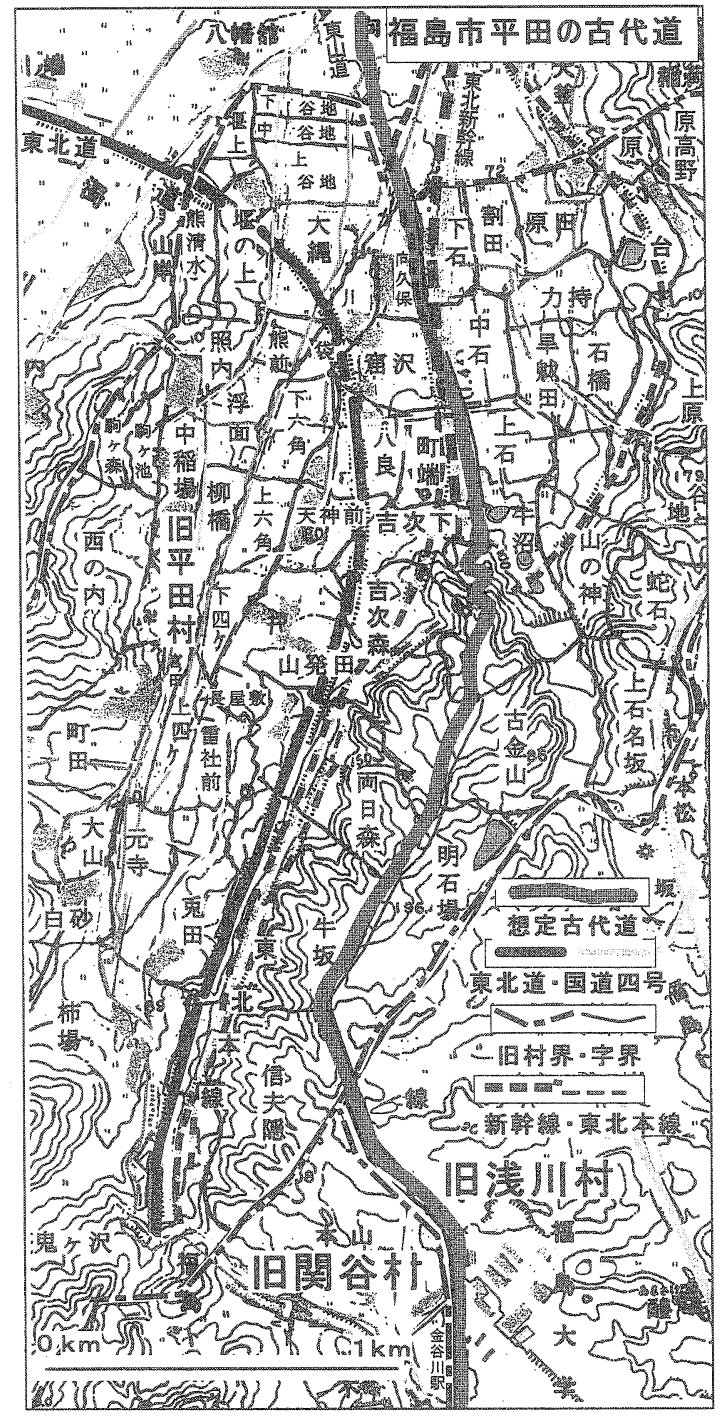

がり道を下ると, 新幹線のトンネルの入りロになる。そ こから字界を北北西の方向で大字永井川の字大橋で濁 川を渡り, 北北東の方向で字界を $2.8 \mathrm{~km}$ をほぼ直線で 永井川，太平寺，郷野目から，方木田に達する。荒川 を渡ると福島の城下町になる。直進すると信夫山にな るので，北東に向きを変える。古代には阿武隈川は右 岸の渡利小学校が流路で, 福島の大仏城 (現県庁) 本 丸が半分に浸食されている。従って, 道の大半は阿武 隈川の河床を陸路で通過して, 上浜町まで来る。県立 福島東高加 $1 \mathrm{~km}$ 北に, 上, 東, 南, 西, 北の宿のつ く字名が並ぶ腰浜を直線で通過する。小山荒井村の字 道通で信夫山を避けるために北東に $200 \mathrm{~m}$ 進み, 旧五 十辺村を条里西端の信夫山の東麓を $600 \mathrm{~m}$ ほど北進 する。東麓の字名に立石がある。

松川から摺上川までの $6 \mathrm{~km}$ は洪積段丘と沖積面が 非連続で存在する。従って, 条里は存在するが連続は しない。条里の余剩帯の調査もしたが, 単位が小さい ために確認は出来なかったので, 直線の連続を問題と した。その結果五十辺から連続して，本内村では館の 西側に凹んだ道型があり，鎌田の条里の線，石森山の 東からは字の境界はないが住宅地にも直線の道型が連 続して，日枝神社の境内には「笠卒塔婆」まである。そ の北の字孫六橋から摺上川までも道型が直線で連続す る。東湯野村では川の左岸には字馬場，馬洗，馬繋が あり，条里水田の字名に東山道の駅名の「岑越」があ り，北東に曲がる村境には字山道がある。この北の西 原には鹿島神社が在る。平田の発掘調査が必要である。

図福島市平田の古代道

\section{盛岡市中央公民館所蔵の幕末蝦夷地陣屋関係絵地図について}

\section{戸祭由美夫・出田 和久 (奈良女子大)。平井 松午（徳島大）。} 小野寺 淳 (茨城大) -中西 和子（奈良女子大）

\section{1. 本研究の目的}

江戸時代後半の欧米列強による極東・北太平洋海域 への進出に対抗して, 幕府は蝦夷地防衛のために箱館 奉行を新置するとともに，東北諸藩に対して蝦夷地沿 岸部の防備を命じた。それに応じて建設された幕府の 箱館奉行所や東北各藩の陣屋に関して，詳細な設計図 や完成図が建設担当者によって作成された。

本研究では, 当時に作成・模写された多種・多様な
絵地図が，箱館奉行所の所在地たる函館市や東北諸藩 の所在地たる弘前・盛岡・秋田・仙台。鶴岡の各市の 図書館・博物館・資料館などに現在も（一部未整理の ままで）保存されていることに着目して，科研費補助 金 [B（2）17320132, 平成 17-20 年度，代表者：戸祭] を得て，それら所蔵機関のご協力のもとに，研究メン バーが直接現地に赴いて絵地図の実物を閲覽・撮影し，

(1) どんな絵地図が残されているのかの確認, 
(2) 同種の絵地図の相互間の本末・系統の推定,

(3) 当該絵地図に関する地図学的加歴史地理学的 な特徴の解明，

(4) その研究成果を地元住民対象に解説・講演する ことによる地域貢献, といったことを目指している。

2. 盛岡市中央公民館所蔵の幕末蝦夷地陣屋関係絵 地図

本発表では，この共同研究で最初に現地調查を行っ た盛岡市中央公民館の所蔵しておられる旧盛岡 (南部) 藩関係の幕末絵地図に関して，中間的な発表を行いた w。

同館の目録の [海防］（35・5）の No. 32〜93（79 〜 80 頁）が本研究に関わる部分で，研究メンバー5 名 で昨年 11 月に該当する絵地図のすべてを実物に当 たって調査した。

その結果，「箱舘陣屋図」(53)「箱舘表諸絵図」(58) 「東蝦夷地図」(63)「蝦夷地各陣屋図」(65)「蝦夷地関 係図」(66)「蝦夷地雑地図」(67,68, 69, 70) と一括り にされている絵地図類の中に，同種の絵地図が多数含 まれている。その多くは南部藩の建設したいわゆる「陣 屋」および渡島半島東岸より噴火湾岸にいたる南部藩 警備地域を扱った絵地図で，なかでも箱舘に設けられ た南部藩元陣屋に関するものは，表装・印影・付箋や 描図の精粗などの点で区別可能なものが多々ある。同
種の絵地図を所蔵する函館市中央図書館をはじめとす る各地の機関所蔵にも調査に赴いて，上に述べたよう な観点から比較・検討を進め，それら相互の関係を今 後解明していきたい。

以下, OHP によって, 盛岡市中央公民館所蔵の幕末 蝦夷地関係絵地図に関して,「箱館の南部藩元陣屋関係 の絵地図」を中心に，テーマ別に概要をお示しし，今 後のわれわれの研究の第一歩としたい。

3. ポスター展示

別室において,「箱館の南部藩元陣屋関係の絵地図」 に絞ってポスターを展示させていただき，下記の絵地 図を収録した。

68-1 箱舘字水元曠野之内元陣屋地之図

66-25 箱舘遠陣屋御引請地所絵図 (一間二分積) 乾

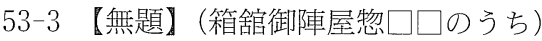

66-26 箱舘表水元御陣屋建図 縮図 坤ノ一ノニ 10 と同じ】

53-1 箱舘水元御陣屋一間二分縮図［万延元年 6 月 改]

66-7 箱舘表水元御陣屋縮図 坤ノ一【58-2 と同じ】

58-3 箱舘表之図 一 【66-19 と同じ】

49 箱舘之図 [安政 2 年 6 月]

また，館蔵の絵地図の閲覽・撮影にご高配を賜った 盛岡市中央公民館にお礼申し上げたい。

\section{「日輪兵舎」の戦後一その解体・復元・保存一}

\section{松 山董（東北公益文科大）}

日輪兵舎とは，第二次世界大戦期に，茨城県内原の 満蒙開拓青少年義勇軍訓練所（以下「内原訓練所」）に 多数建設された，訓練生の宿舎兼教育施設である。独 特の円形プラン・円錐形の屋根をもつこの建物は，内 原訓練所および満蒙開拓青少年義勇軍制度の象徵とし て, 当時広く認識されていた。本研究は, 戦時中の思 想を体現したこうした建造物が，戦後どう扱われ，い かなる意義付けを受けてきたかを，いくつかの事例を 通して考察した。

終戦後, 内原訓練所は閉鎖され，土地建物の大部分 は全国農業会や財団法人開拓民援護会などに引き継が れた。内原訓練所の日輪兵舎は，終戦直後に大部分が 取り壞され，木材は水戸の戦災復興住宅の建材として 用いられたと当時の新聞は報じている。

また戦時中は，国策としての義勇軍制度が地方に浸 透するにつれ，内原訓練所の日輪兵舎を模した建造物
が全国各地に造られた。発表者は 2006 年 5 月現在，開 拓研修等を目的とした戦時中の日輪兵舎形の建造物 (本研究ではそれらも「日輪兵舎」と総称する) の存在 を，20 近い都府県の約 40 ケ所に認めている。それらが 戦後どうなったかについての全体的な趨勢はいまだ明 らかではない。しかし，それぞれの建設主体（地方自 治体，教育会，学校，財団，個人など）が自発的に内 原訓練所の日輪兵舎を模した建物を建てていたにすぎ ないため，たとえば奉安殿のように通達により制度的 に解体されるという事態は生じていない。加えて他用 途に転用可能であり，戦後も使用され続けた事例もあ る。具体的には, 疎開者の仮住居, 農業作業場，倉庫 などの用途が見うけられる。それらの中には現存する ものも数棟あり，近年登録有形文化財としての登録が 計画されているところもある。

さて，終戦からかなりの時間が経過した昭和 40 年 
代，各地で満州開拓関係者らによる「満州開拓史」の 出版(しばしば都道府県単位で編纂されている)や，死 亡した開拓移住者の慰霊を兼ねた記念碑（「拓魂碑」と よばれることが多い）の建立がさかんになった。その なかに，満蒙開拓青少年義勇軍の象徵的存在であった 日輪兵舎の再建・復元の機運が生じたところがあった。 たとえば三重県大台町では，満州開拓関係者，県市 町村などの協力のもと，1969 年に県有地の貸与を受け て拓魂碑が建立されたのに続き，1973 年には同じ敷地 に日輪兵舎を再現した建物（「三重日輪兵舎」）が建設 された。同町にはもともと戦前には日輪兵舎は存在し なかったが，満州送出者数が最も多い地域の一つであ る大台町が，全県レベルでの記念・慰霊の場として選 ばれたことにより, 象徴的意味合いの強い日輪兵全が 建設されたわけである。
日輪兵舎の「本家」である内原訓練所においては， 1985 年に義勇軍関係者を中心とする団体により, 内原 町（現・水戸市）の援助を受け「日輪舎」の名称で小 規模な日輪兵舎一棟の復元がなされた。さらに2003 年 には，義勇軍関係の展示と遺跡出土品などその他の郷 土史関連の展示を併設した「内原町郷土史義勇軍資料 館」（現「水戸市内原郷土史義勇軍資料館」）が内原町 によって設立され，全国の開拓関係者からの寄附も活 用された。同資料館の敷地には新たに標準的な大きさ の日輪兵舎一棟が復元された。

こうした施設は, 開拓関係者の記念・慰霊行為の場 としての機能と, 歴史を後世に伝えるという展示機能 の双方を兼ね備えているが, 関係者の高齡化が進み, 前 者の機能は徐久に形を変えつつある。

\section{近代日本における「都市下層社会」の表象}

遠 城 明 雄 (九州大)

\section{Akio ONJO : On Representations of the 'Urban Underclass' in Modern Japanese Society}

\section{1. 問題の所在}

明治期以降，「都市下層社会」について多くの表象が 生産されてきた。例えば松原岩五郎や横山源之助など ジャーナリストによる探訪記事, 各市の社会局(課)な ど行政機関や研究者による社会調查，民間有志者によ る救済記録など，その数は膨大であり，また分野も多 岐にわたっている。本発表は，特に明治後期から昭和 初期にかけての都市社会の構造変動を考慮に入れなが ら，当該期の地方都市（北九州地域）における下層社 会の表象の特徵について検討するものである。

2.「視察」という行為をめぐって

1911 年夏に門司市の「貧（細）民窟」を訪問した刑 法学者小河滋次郎は，下層社会の人久の生活スタイル について興味深い傾向を発見したと発言している。そ の発見とは，家屋をはじめとした生活環境はきわめて 劣悪であり，居住者（その多くは石炭仲仕などの港湾 関係労働者）も裸体で雑居して生活するような状態で あるのに対して，その賃金が他地域と比較して高い点 であった。小河は，この点から下層労働者たちが飲酒 や高価な食料に貨金を浪費してしまうことを貧困の一 因と考えこうした生活習慣の改善こそが貧困解決に とって最も重要な要素たと考えるようになった。異質 な生活慣習や思考様式を強調し，「一般社会」から切り 離された異質な世界として下層社会を表象すること
は，小河にとどまらず明治後期から一般的に見られる 特徵であり，細（貧）民たちは改良されるべき対象と して位置づけられることになる。そして中央の権威あ る人物による視察は，こうした表象により強い規範的 な力を付与する行為であったといえる。

3. 自立と救済のはざまで

米騒動を経て昭和初期になると, 不況からさまざま な社会問題が深刻化した。この時期に新聞各紙は, 細 民救済の寄付金集めを意図した細民街の探訪記を連載 するようになる。こうした細民街の叙述をみると，生 活環境や習慣，特に衛生観念の欠如などの叙述の仕方 は明治後期とほぼ共通しているが，細民たちの生業や 生活の有様（相互扶助など）がより詳細に紹介されて いる点で若干の視点の移動が見られる。その直接的な 要因は，これらの記事の目的が寄付金集めにあり，貧 困を読者に対してより身近な問題として描く必要が あったことにあると思われる。しかし行政や関係者が 期待したような社会階層の人久による寄付金拠出は少 なかった。当時，自治の担い手（あくまでも国家に奉 仕する者であるが）となる「市民」の形成が多くの市 で模索され，『市民読本』なども製作されていたが，そ れはうまく進んでいなかった。こうして下層社会は, 同 情の対象とされることによって市民形成のための「否 定的媒介」としての役割を担わされることにもなった。 
また間接的な要因としては，下層社会の人久も，救済 の対象としてのみならず，一般社会に統合され自立を 期待される存在として表象されるようになったことが 考えられる。例えば大正末期に設置された方面委員事 業は，地域的連带にもとづいて下層社会の救済と自立
を目指した制度であり，下層社会に対する視点の変化 を生じさせる契機のひとつとなった。ただし下層社会 を異質な社会として見る表象は部分的に連続してお り, 視点の移動は表象の布置関係全体を変えたわけで はなかった。

\section{宮沢賢治の寓話「黒ぶだう」と花巻。菊池邸との関係 ーイーハトヴにおける岩手と北海道の重合の例一}

\section{米地 文夫（ハーナムキヤ景観研）。木村 清且（岩手県立大・院）}

宮沢賢治の寓話「黒ぶだう」は，生前未発表の作品 で, 原稿のみ残されており, 仔牛が赤狐に誘われて, 無 人のベチュラ公爵別荘に入り込み，二階で卓上の黒ブ ドウを食べる。狐は汁だけ吸い取り，仔牛は種まで噛 む。公爵らが帰ってきたので, 狐はバルコンから逃げ， 残された仔牛に伯爵の娘がリボンを着けてやる。

演者らはこの公爵別荘のモデルが，花巻市街に現存 する菊池邸であることを見いだした。賢治は花巻の町 をハーナムキヤあるいはハームキヤなどと欧風に呼 び，そのイメージを創る際に当時の花巻にあった洋風 の建物をモデルにしたのである。花巻市里川口，御田 屋小路の菊池捍（まもる，1870-1944）邸母屋は，旧宅 が類焼したため，1926 (大正 15) 年末に新築落成した。 木造二階建て，外観は洋風，内部は打打む称洋風なが ら各室は畳敷きの和室という家屋である。「黒ぶだう」 の記述に，通常の洋館としては不自然な部分が数箇所 あるのは菊池邸をモデルにして書かれたためである。 特に注目される点は「黒ぶだう」の洋館に「わき玄関」 があることである。菊池邸には本玄関と脇玄関があり, 格式ある名家が貴賓客や冠婚葬祭の来客のために本玄 関を用い，通常は脇玄関を用いる，この地方の伝統的 な和風建築の様式を洋館に取り入れている。普通の洋 館とは異なり，二つの玄関が風除室として外に張り出 した形になっており，「黒ぶだう」の洋館も同じ構造に 描かれている。また狐は逃げる時に「バルコンへ飛び 出しひらっと外へ下り」てしまうが，菊池邸二階の空 先棚は，普通の洋館の場合よりも約 $60 \mathrm{~cm}$ 低く，外見 はバルコニー風にみえる。その棚の下には玄関の屋根 があり，楽に外へ降りられるのである。
「黒ぶだう」の洋館の主はべチュラ公爵で，来訪した 友人はヘルバ伯爵と名付けられている。ベチュラはカ バノキ科（属も）の学名 betula，ヘルバも同じくラテ ン語で草の意の herba から付けられたと考えられる。 英語の herbage は牧草を意味し, herbivore は牛など の草食獣を指す。花巻出身の菊池捍は白樺そよぐ札幌 農学校で学び卒業論文は「家畜飼養原理」, 同校助教授 としての「動物生理」を担当した。そ机故，牛を主役 とし，人名も関連したものを選んだのである。

当時，捍は明治製糖の十勝清水工場長であった。ま た同郷の北大総長佐藤昌介は捍の義兄で，妹の捍夫人 がこの屋敷の新築を取り仕切った。また佐藤昌介は賢 治も面識があり尊敬していた。佐藤昌介家への男爵授 位が内定した時期に当たり，これが作品に華族を登場 させる機縁になったらしい。白樺，牧草，酷農という 北海道の雾囲気を花巻に重衫合わせて，洋風のイ一八 トヴのイメージを賢治は描いたのである。

狐がブドウの汁を吸い，仔牛が種まで噛む，という 設定も，菊池捍の工場が甜菜を搾って製糖を行い，そ の搾り滓のビートパルプを道内の乳牛の飼料として販 売していたことと関わっているらしい。

これらのことから演者らは，菊池邸が賢治作品「黒 ぶだう」に登場するべチュラ公爵別荘のモデルである ことを立証した。宮沢賢治はイーハトヴを岩手県のみ ならず遠く北海道にも続くものとイメージしていた (米地，1996)。べチュラ公爵別荘に見立てた菊池邸は， 岩手に北海道を重合し，そのイーハトヴ世界の北方的 風物，欧風の景観を具現化したものなのであった。 


\title{
間伐施業の実態と地域林業の新展開 一宮城県・石巻地区森林組合を事例としてー
}

\author{
多田忠義（東北大・院）
}

Tadayoshi TADA : Realities of Thinning and New Expansion of Regional Forestry : A Case Study of Ishinomaki District Forest Owners' Cooperative, Miyagi Pref., Japan

第二次世界大戦後, 戦後復興と高度経済成長によっ て引き起こされた木材の急激な需要, 及び造林に対す る国の補助制度の整備が空前の大量植林を招いた。そ の後の経済自由化は外材の大量輸入を促進し, 国内造 林における採算性の悪化で, 造林意欲の減退を招いた。 このような林業を取り巻く経済条件の変化は, 戦後大 規模に行われた人工林の維持管理不足を生み，間伐を 必要とする林野を急増させ, 森林資源の荒廃や風害, 雪 害など林地災害の多発を生み出す危険性を増してい る。

本研究では, 宮城県石巻地区 (現在の石巻市, 東松 島市，女川町）を対象に1. 間伐の実施・未実施を決め る条件 2. 新たな間伐材利用体制の効果について実 証研究を行った。

石巻港には全国有数の規模を誇る合板工場が集積し ており，原木の一大消費地でありながら，地元の木材 が材料として利用されることはなかった。しかし, 原 油価格の高騰による輸入材価格の上昇と間伐材の利用 促進を図りたい森林組合や行政の利害関係が一致し, 「森林資源パイロット事業」として石巻地区の間伐を促 進しようとする，今までの林業に関わる補助制度にな かった新たな取り組みが展開された。具体的には, 間 伐材を合板会社に売却し，その売上金で間伐実施のコ ストと山林所有者の収入を得ること，それと同時に間 伐実施から間伐材の納入までの流通システムの構築, また間伐材を合板の材料として利用できるよう，合板 会社へ生産機器の補助を行うことの大きく 3 点であ る。さらに, 石巻地区森林組合はウッドリサイクルセ ンターを設立し，販売できない間伐材などをチップ化 して販売し，利益を組合員に還元するシステムを構築 した。そのような地域において，林家の山林管理実態 を把握し，新たな間伐材利用体制がぞの程度効果的
だったかを把握することは, 間伐の実施・未実施を決 定づける要因との関連性を明らかに出来ると考えた。

調査は, 宮城県, 石巻地区森林組合, セイホク株式 会社への聞き取り調查を実施して, 宮城県や石巻地区 に扔ける林業の現状，そして新たな間伐材利用体制の 運用状況について把握した。続いて, 石巻地区森林組 合の間伐事業受託件数の多い地区を選定し，その集落 に住む組合員へ郵送によるアンケート調査を実施し， さらにその回答者のうち協力を得られた方に対して, 面接による聞き取り調査を実施した。

石巻地区の森林は, 全国の齢級に比べやや高齢級で あり, 現行の間伐補助制度では対応できない山林が あった。そのため，新たな間伐材利用体制は間伐を促 進する制度として有効に活用される見込みがあった。 しかし, 調査した山林の間伐は所有山林面積の規模が 大きいほど実施されやすく，間伐を実施するかしない かを決める条件は, 採算性から生じる所有山林とのア クセス性に集約された。また，間伐材の伐出で採算を 向上させるために必要となる「間伐実施林分の団地化」 は, 財産保持や, 他者の介入を快く思わないなど, 林 家各々の思惑が交錯して思うように進まず，結果比較 的山林面積の大きい場所からこの制度を活用した間伐 が実施されていた。石巻地区において小規模山林所有 が多いため,この制度は一部の山林所有者にとっては 有効に活用されているものの, 石巻地区全体の山林所 有者にとって必ずしも有効に活用されていないことが わかった。そのことは, 新たな間伐材利用体制に対し て一定の評価をするものの, 自分達とは縁遠いものと した林家の声からも裏付けられる。故に, 現状の間伐 材利用体制を小規模山林所有者にとって利用しやすい ものへと変容させる必要がある。 


\section{過疎・高齢化に伴う焼畑集落の変容 一山形県旧温海町小菅野代・峠の山・鍋倉集落を事例として一}

農産物の市場開放を迫る国際情勢，地勢による不利 な地理的条件，不安定な就労環境など，国内の中山間 地域を取り巻く環境は非常に厳しい。しかし，実際に 中山間地域を調査するなかで気付くのは，集落での農 業の担い手不足，人口の定住問題，後継者の嫁取り問 題など，集落が内包的に抱える問題であり，また，そ れに対応した施策が充分に行われていない事実であ る。

今回は，過疎・高齢化が深化するなかで，中山間地 域に抢ける農業の立地条件に適合した焼畑カブを栽培 して，かろうじて集落の維持を図っている山形県西田 川郡旧温海町の中山間地域を事例として取り上げ，こ うした状況のもとで, 何が集落を維持させているのか, 集落に扔ける焼烟農耕の実態に, 労働力補完, 農地管 理, 共同体組織の内容を加え, 焼畑集落の変容を調査 した。

焼畑カブの栽培は，年金のみに頼る高齢者世帯に とって貴重な現金収入となるため，非農家を含む多く の世帯で栽培している。しかし，かつて結によって確 保されていた労働力は, 過疎・高齢化により, 結の相 手が限定され, さらに, 結を交わす双方の労働力が不 均衡となっているため，互いに依頼し難い関係が生じ ている。これはかつて農業機械の導入に伴って生じた 相互扶助の脆弱化とは明らかに異なる。そこで結に代 わる新たな労働力補完として, 旧町内にあるシルバー 人材派遣センターを活用している事実が明らかになっ た。

各集落における農地管理をみると，標高の高い場所 に位置する 2 つ高位集落の比較から, 受託経営農家 を確保しやすい平坦地に水田を所有している集落で, 集落の人口が維持されていることがわかった。また, 委
佐々木 英 慧（上越教育大・院）

託契約を結ぶ際, 受託経営農家側に農業後継者が同居 していることを重要視していることが判明した。そう した受託経営農家が集落に存在することが，集落維持 にとって重要となっている。さらに，集落に抢ける退 職者専業農家の存在が集落営農の中心的な担い手とし て期待されている実態が明らかとなった。

集落の共同体組織をみると,かつて集落の代表者は, “親方衆”之呼ばれる特定の人々が務めていた。しか し, 給料生活者の増加によって, 代表者は集落内から 広く選出されるようになり,さらに, 過疎・高齢化に よって少数の人久による輪番制となり，さらに特定の 人物が長期間にわたって代表者を務める状況へと変化 している。これは，特定の人物と同等に集落をまとめ る行動力や経験, 資産を兼社備えた人物が集落に見当 たらないことによる。

集落の自治会費徵収に関しても，かつて個人の財産 に応じて等級化されていた徵収基準は，現金収入に応 じて徵収されるようになり，さらに過疎・高齢化の深 化によって，上層農家の負担が，年々，増加している 実態が明らかとなった。

また，共同作業のうち，かつて共同で行っていた除 雪作業は, 参加者不足による労働の負担過大を理由に, 報酬を現金で支払う形態に変化している。

高付加価値の農畜産物を生産する農業は, 中山間地 域農業の発展に必要な条件である。研究対象地域にお ける焼畑カブの栽培は，商品作物として地域振興を支 え得る作目であると考える。しかしながら，現状をみ る限り, 必ずしも地域農業の軸とはなっておらず, 過 疎・高齢化の深化のなかで，集落維持の基底を支える 機能を果たすに留まっている。

\section{分布論的にみた日本列島のクリと人間との関係}

$$
\text { 元木靖（埼玉大） }
$$

Yasushi MOTOKI : Geographical Distribution of Chestnut Tree and its Social Implications in Japan

1. 北海道西南部から九州にかけて自生するクリ (シバグリ castanea crenata) は，クルミやトチノミ等 の堅果類と共に早くから，日本列島に住む人々の重要
な食料であった（西田 1989 ; 渡辺 1996)。とくに綶文 遺跡から出土したクリの分布が東北地方から中部地方 に多い（千野 1976；安田 1998; 渡辺 2000; Kitagawa 
2004）という事実は，東日本においてクリと人々との かかわりが深かったことを示している。もちろん，こ れは西日本におけるクリと人々とのかかわり合いを寡 少に評価させるものではない。稲作開始以降もクリは 保存食料として重要な位置にあったが（西田 1989 ; 渡 辺 1996)，砂グリ（貯蔵クリ）の分布を調査した过 (1994)によると，その慣習はほとんど全国に及んでお り，地域差は認められない。

2.ささ，わが国において今日の園芸種である丹波 系クリはシバグリから改良されたもので，その出現は 東日本ではなく西日本であった。しかも，その発祥地 は畿内周辺の地域であることが確実となっている（志 村 2003)。西日本では通常食のようなクリの役割がも ともとなかったか，あるいは稲作の普及につれて相対 的に低下し，一方で社会の発展に対応して，クリの新 しい役割が期待されるようになったことが，背景とし て考えられる。とくに丹波グリの発生が畿内周辺で あったことに着目して言うならば，都市的な環境の形 成ということが大きく関与していたのではあるまい か。その際,丹波系クリの成立が自然発生的な形をとつ たのか，特定の改良者が存在したのかは明らかではな い。しかし，古代国家が成立してから近世に至るまで の間に，大粒のクリが注目され（記紀をはじめ多くの 書物に記録)，王朝時代の献上物として，あるいは江戸 時代の参勤交代のときのみやげ物とされた記録が残さ れていることは，注目す心゙きことであろう。つまり，ク リはこの過程で常食や保存食としてではなく，いわば
今日の菓子のような役割をも持つようになり，それに よって丹波グリの成立が可能になったのではなかろう か。明治 10 年代の勧農書（梅原・濱村 1885）に，「栗 八丹波栗又八中丹波栗卜称するモノタ最良卜ス」とあ ることからみて，丹波グリは少なくとも江戸時代末頃 までには成立し，畿内外の広い範囲に通じていたと考 えられる。

3.クリと人々とのかかわりについて考える場合, クリの実だけが注目されてきたわけではない。前述の 勧農書をはじめ明治期から大正年間までのクリ栽培に 関する文献では，クリを果実(救荒食，菓子，儀礼食， 乾栗，焼栗等）と，材（枕木，莫板，薪炭材，建築材 料等)の両面から評価し，奨励している。したがって， 栽培管理上から言えば，当時の丹波グリの場合もシバ グリと大きな区別はなかったものとみられる。

昭和期頃からの官庁統計（林業副産物としてのクリ と栽培グリの生産統計)によると，少なくとも1960年 頃までの林業副産物としての生産地（シバグリを中心 としたものと考えられる) は全国的に分布していた。し かし経済成長期以降はクリ材利用の減少と，クリ玉蜂 被害により，この種のクリ生産は急速に減少した。こ れに対して丹波系品種の栽培は，近代都市が成立する 過程で商品生産のための果樹として発展し，第二次大 戦前から戦後にかけた成長期には茨城，愛媛，熊本等 の，むしろ都市から離れた，あるいは遠隔の地（西南 日本）に産地形成を図るようになった。

\section{岩木山登山道のゴミ}

\section{藤崎 浩幸 (弘前大) ・中島 大介 (パナホーム愛岐)・谷口建（弘前大）}

\section{Hiroyuki FUJISAKI et al. : Litter of Climbing Path of Mt. Iwaki}

\section{1. はじめに}

登山道のゴミについて，ゴミ持ち帰り運動や清掃登 山の実施などにより，以前に比べ良くなっているとい う話を耳にすることもあるが，そもそも，登山道のど ういう䇢所に，どのようなゴミが存在するのかといつ た実態を明らかにした文献は見あたらない。そこで,本 研究では，青森県に位置する岩木山の登山道を対象と し，そこに落ちているゴミを収集し，その分布など分 析することを目的とした。

2. 岩木山登山道の概要

青森県西部に位置する岩木山は, 標高 $1,625 \mathrm{~m}$, 津軽富 士とも呼ばれ津軽地方を代表する山として津軽一円の
人々から愛されると同時に，岩木山神社のご神体であ るなど信仰の対象にもなっている。主な登山道は，南 西から岳登山道(延長 $4.9 \mathrm{~km}$ ), 南東から麓に岩木山神 社がある百沢登山道 $(4.7 \mathrm{~km})$ ，東から弥生登山道 (5.6 $\mathrm{km})$ ，北東から麓に赤倉神社がある赤倉登山道 (5.3 $\mathrm{km})$ ，北西から長平登山道 $(3.8 \mathrm{~km})$ である。1965 年 に岳登山道のやや西寄りにその 8 合目まで岩木山スカ イラインが開通し，そこからリフトで 9 合目まで行け るようになったため，観光客が気軽に登山できるよう になった（以降では，岳登山道の 8 合目以上を「8 合目 以上」と呼び，「岳」とは岳登山道の 8 合目以下を指す こととする)。青森県資料では，平成 16 年度の岩木山 
登山者数は 25,600 人とされている。

3. 岩木山登山道の管理

岩木山は大部分が国有地であるが，登山道など実質 的な管理は旧岩木町が行っていて，山頂にある祠など 部分的に神社などが管理している箇所がある。役場担 当者の聞き取りから，登山道の清掃は，5月から 10 月 の間，役場が委託した 3 名が延べ 140 日間の清掃を行 い, 年間 $34.2 \mathrm{~kg}$ のごみを収集している。この他に, 関 係団体などを交えて構成される岩木山環境保全協議会 主催で 7 月に岩木山クリーン作戦が行われており，麓 の百沢スキー場，自然歩道などと同時に，岳登山道も 対象となっていて，その際，約 20 名が 2 時間かけ約 5 $\mathrm{kg}$ のゴミを収集した。

なお，登山道ごとの利用者数について公式な資料は 皆無であるものの, 岩木町から清掃を受託している作 業員の話によると，8 合目以上を 100 とすると，岳 15 , 百沢 10 , 赤倉 5 ，弥生 1 ，長平 1 程度と推測される。

4. 岩木山登山道のゴミ

2005 年 10 月 3 日〜 11 月 1 日のうち 13 日間に, 登山
道（長平を除く）を実際に踏査し，発見したゴミの位 置を携帯型 GPS 受信機で把握し，種類・サイズ・状態 を野帳に記録した。特徵的なごみは写真撮影した。そ して見つけたゴミはまとめて持ち帰り下山後に総重量 を量った。今回の調査で得られたゴミの総数は 3,447 個，総重量 $65.6 \mathrm{~kg}$ であった。

ゴミの種類は，個数の多い順に，ガラス片・ビンが 全体の 4 割近く, 次いで菓子袋, タバコの吸い殼，缶 などである。分布は，個数比では，赤倉，山頂に 3 分 の 1 ずつ，次いで 8 合目以上に存在し，重量比では赤 倉が 3 分の 2 を占める。またどの登山道においても, 休 㦝点以外の区間に比べ休㮩点に集中して落ちていた。

赤倉で利用者数に比してゴミが多いのは，お供え物 がゴミ化していること，清掃受託者がいるにもかかわ らず，今回かなりの量のゴミを収集できたのは，受託 者が古いもの，小さなもの，ゴミ化した抢供え物を見 過ごしていることが推測された。

\section{白神山地周辺地域にみられる自然資源利用の地域性}

\section{㯟原 智美（弘前大・院）・嶋村 道。牧田 肇（弘前大）}

青森県西目屋村の目屋マタギに代表されるように， 世界遺産である白神山地周辺の集落では伝統的に自然 資源を利用した生活が営まれてきた。本研究ではその ような自然資源を利用してきた集落のなかでも，白神 山地の一角を占める青森県西目屋村砂子瀬地区，青森 県深浦町松原地区，秋田県旧峰浜村 (現八峰町) 岩子 地区・大岱地区で行われてきた自然資源を利用した生 活の様子を明らかにした上で三地域の地域性について 述べることを目的とする。

調査は主に現地で聞き取りを行った。砂子瀬地区は 工藤光治氏から,松原地区については前田秀夫氏から， 岩子地区・大岱地区については塚本清氏から聞き取り を行った。塚本氏は 21 年前に大岱地区から岩子地区に 移り住んでいる。

砂子瀬のマタギは目屋マタギと呼ばれ，白神山地を 代表するマタギの本流といわれており，伝統的な狩猟 儀礼が残っている。松原のマタギは目屋マタギの系統 を踏むものと考えられ，「えんど渡し」と呼ばれる狩編 儀礼があった。岩子・大岱では，狩猟儀礼というもの は特になく，伝統的なマタギではなく自然発生的に生 まれたものと思われる。

砂子瀬では,山菜のゼンマイを換金資源にしていた。
岩子・大岱ではボンナ（イヌドウナ）とシドケ（モミ ジガサ) は換金資源に今日でもしている。砂子瀬では, 重要な換金資源であったゼンマイは手で採取し，岩 子・大岱では鎌で採るという大きな違いが見られた。ゼ ンマイでは，手で簡単に折れるところまでがやわらか くおいしいところとなり，ボンナとシドケは鎌で採ら ないと見た目がよくないという理由から採り方が異な る。

製炭業は 3 地区とも日帰りで行ける範囲で行い，白 炭を焼いていた。炭焼きの時期は砂子瀬では，夏と冬 の農閑期に，松原と岩子・大岱では，主に冬の農閑期 だけで行った。1 俵あたりの炭俵の重さは砂子瀬と松 原では 4 貫目と同じで, 炭俵は自家製だったが, 岩子・ 大岱では重さが 5 貫目と重たく炭俵は仲買を通して購 入していた。

焼畑は砂子瀬のみで行っていた。役畜は砂子瀬と松 原では農耕馬が各家庭に一頭だけ飼育され，岩子・大 岱では, 肉牛を各家庭に 10 数頭と農耕用に和牛を一頭 飼育していた。採草地は役畜の飼料として利用されて いた。砂子瀬と松原では採草地に名前が付いていて,岩 子・大岱では，夏は牛を放牧していたのでそのための 放牧地と冬の保存用の採草地という区別がされてい 
た。

自然資源の利用は，砂子瀬地区と松原地区では，自 給的な色彩が濃く，岩子地区・大岱地区では，企業的 な色彩が濃いように思われる。具体的には，砂子瀬地 区では，農地が少なかった為に焼畑が行われ，また両 地区ともマタギと呼ばれる人が伝統的な狩猟を行って
いた。岩子地区・大岱地区で特に企業的に行われてい たのは牛の飼育だった。昔から大規模な畜産業が行わ れていた。炭焼きでは炭俵を仲買を通して購入してい た。山菜は現在でも換金資源であり，昔からもっぱら 売ることを目的に利用してきた。このような点から企 業的な色彩が濃いと考光られる。

\section{札幌市における集合住宅の立地変化}

沼田 尚也（北海道大・院）・橋本 雄一（北海道大）

高度成長期後, 日本の大都市では，都市全体の人口 増加が続く中にあって都市内部では都心および都心周 辺の人口が減少傾向にあった。しかしながら，1990 年 代後半から 2000 年代初頭にかけて,多くの大都市では 都心とその周辺における人口増加が報告されている。 本研究の対象地域である札幌市も戦後一貫して人口は 増加傾向にある。また，都市内部の小地区ごとの人口 増減率は, 2000 年以降都心抒よび都心周辺部で増加に 転じている。これにより札幌市では，他の多くの日本 の大都市と同様に，人口の都心再集中が生じている。

本研究は札幌市を対象として，主に集合住宅の立地 傾向の変化を明らかにする。これにより人口の都心再 集中の解明に住宅の視点を加えることを目的とする。 札幌市への転入人口は都心とその辺縁へ流入する 10 代後半から 20 代の年齢階級が中心である。また, 転出 人口も同様の年齢階級だが，この年齢階級における転 入超過がそのまま札幌市の人口増加につながってい る。また，都心とその周辺への滞留を促す都市内人口 移動によって札幌市に抢ける都心再集中は進展してい る。

最近 10 年間に札幌市に提出された住宅建築申請数 は 2001 年まで減少傾向にあり, その後増加している。 そのうち戸建住宅の申請数は 2001 年以降も微減傾向 にある。このため新規の住宅立地において集合住宅の 割合が高くなってきている。また，近年の新規住宅の 立地は, 都心とその周辺部に抢ける高層住宅の建設が 卓越する傾向にある。さらに，集合住宅のうち，定住
人口の受け血となる民間分譲マンションについて，北 海道住宅年鑑より 1975 年以降の 10 年ごとの新規立地 を札幌市統計区別に分析した。これにより札幌市にお けるデベロッパーの供給動向が明らかとなる。

その結果, 札幌市の分譲マンションは 1975 年までは 都心部と南北線沿線への立地が多い。次の 10 年間では 地下鉄の新規開通・延伸と市街地の外延的拡大ととも に分変マンション立地の分散がはじまる。1985 年 〜1995 年の 10 年間は，1988 年に開通した地下鉄東豊 線沿線や厚別副都心への立地も進み，マンション立地 の外延的分散傾向がさらに進展している。しかしなが ら,バブル崩壊後の近年 10 年間は分譲マンションの立 地が再び都心と都心周辺へと集中する傾向にある (図)。

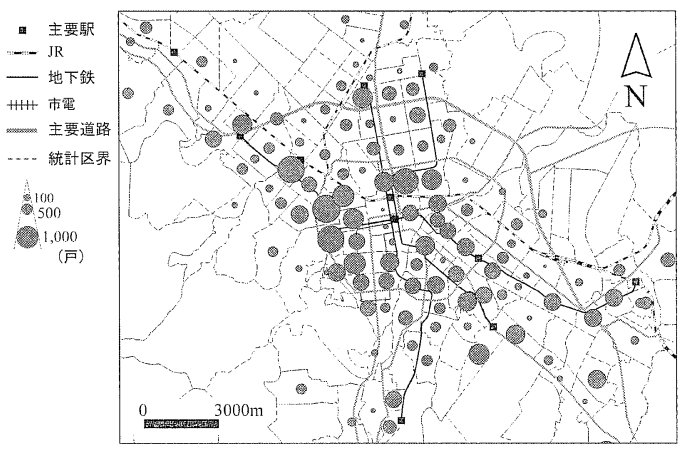

図＼cjkstart新規分譲マンションの立地（1995 年〜2004 年）

\section{仙台の都市・建築計画における均質空間の問題構制}

ル・コルビュジェに代表されるモダニズム的な都 市・建築デザインは, 20 世紀後半から, 均質性がもた らす弊害が批判されがちであった。だが，異質な人び とが共生可能な新しい「場所」のあり方を探求すると

\section{大 友康 博 (東北大・研)}

き，全ての人びとを受け入れ可能な均質空間を母胎に 置いてこそ，希望が持てる空間計画を構想できるので はないか。また仮に均質空間批判が有効だとしても,そ こで代案となるはずの非均質空間は，これまで概念整 
理すら不十分ではなかったか。

80 年代以降の都市・建築デザインを整理してみる と，均質空間と非均質空間を絡み合わせたさまざまな 模索は，次に示す 6 思想の組み合わせ方の問題であっ たことがわかる。

(1) 均質空間の美学: 空間の連続性を意図的に拡 大。社会の連続性を切断。時間を保留。

(2) 表層・透明志向：空間の連続性を意図的に拡大。 時間の連続性を切断。社会を保留。

(3) シンボリズム：時間の連続性を意図的に拡大。 社会の連続性を切断。空間を保留。

(4) 歴史主義: 時間の連続性を意図的に拡大。空間 の連続性を切断。社会を保留。

(5) 協㗢のプロセス: 社会の連続性を意図的に拡 大。空間の連続性を切断。時間を保留。

(6) ノード・バリアフリー: 社会の連続性を意図的 に拡大。時間の連続性を切断。空間を保留。

そして，20 世紀的都市・建築デザインを 6 思想の組 み合わせの問題として捉え直すとき，さまざまな論争 の根本要因や，次代に向かう都市再編の可能性が見え てくるのである。本研究は，仙台の都市計画や建築設 計趣旨を分析することをと抗して，新しい都市・建築 デザインの提案に迫ることを目的とした。

仙台の諸事例を分析すると，近年は 2 つのベクトル があるようにみえる。ユニバーサル空間化と地域クラ スター化である。前者は，「(2) 表層・透明志向」と「(6) ノード・バリアフリー」の混合理念である。たとえば, せんだいメディアテーク設計競技や，定禅寺通の景観 行政, 広瀬通の現代建築群等から析出される。後者は,
「(4) 歴史主義」と「(5) 協働のプロセス」の混合理念で ある。たとえば，“杜の都”イメージ戦略，百年の杜づ くり, 青葉山公園計画等加析出される。

ところが先の分析図式で考えると，ユニバーサル空 間化と地域クラスター化は相容れない関係にある。実 際，青葉山公園計画をめぐる議論では，両べクトルが 激しく衝突している。ユニバーサル空間化がもつ時間 裁断志向は, 後者の歴史・文脈重視の価值体系を貶め ようとするし，地域クラスター化がもつ空間裁断志向 は，前者の領域横断的空間像を破壊するからである。

こうした分析から，新しい都市空間編成をどのよう に構想できるのか。本研究の政策提案は, 以下のよう に要約できる。

均質空間が実体化された都心や新興開発地区等で は，次なる理念を自由に描くことができる。ここでは “都市単位”で地域クラスター化を続行する。しかし小 さなスケールでは,身体的差異の顕示化を防ぐため, ユ ニバーサル空間化へ “ゆっくり”移行させる。さらに, 両極へ分裂しがちな 2 つのベクトルを束ねるために， 自治体が (5) 市民協働と (6) 情報公開を使い分けながら 調整するといった都市管理のあり方を提案する。

片や非均質空間（木造住宅密集地区等）では，多く の構想は実体化され得ない残存理念と衝突するばかり である。ここでは理念をこえた実践こそが，解放への 道筋を切り拓く。つまり，物理的には暴力的改変と小 規模多発的実験，社会的には想定外用法の多様化，心 理的には空間的想像力の爆発的拡張という空間的実践 の先行である。

\section{仙台市における市街地景観の変遷と景観計画の妥当性}

\section{山田浩 久 (山形大)}

Hirohisa YAMADA : Changes of the Scenery in Urban District and the Validity of the Landscape Ordinance in Sendai City

わが国においては 1990 年代頃から, 景観の持つ意味 の重要性を再認識する視点に基づき，景観計画を都市 計画に組み込む自治体が増えているが，現存する街並 みを大きく変化させるような改変は不可能であり，居 住者の頻繁な転出入や来訪者の増加は，空間に対する 共通意識を困難なものにしている。本研究では，巨大 な城下町を基盤に形成されたものの, 第二次大戦中の 空爆によって，戦後，大きく空間構造を変化させた仙 台市を事例として，市街地景観の変遷を整理する。そ
して，歴史的な脈絡の中で形成されてきた景観に対す る認識の差異を山形大学の学生をサンプルにした実験 から考察し,仙台市の景観計画の妥当性を検討する。研 究の結果は以下のように要約される。

仙台城下町は，青葉山と榴ヶ岡を結ぶ直線を基本軸 とし，それに平行する大手筋（大町）と直交する町通 り (国分町) によって構成された。町通りの北端の北 山に青葉神社, 南端の向山に愛宕神社を配したのも自 然景観を都市施設配置の基準としたことの現れであ 
る。両街路の交差点は「芭蕉の辻」と呼ばれ, 四辻に はシンメトリカルな楼櫓式の町屋が建設された。これ ら 4 軒の町屋は軒高が統一された街路によって強調さ れ，その中心地性は，戦前まで維持された。しかし，大 町は戦後の復興事業によって新設された青葉通りの裏 通りとなり, その後, 仙台市の中心地は駅前に移動し た。現在, 国分町の北部は歓楽街, 国分町の裏通りで あった東一番町はアーケード街として機能しているた め, 「芭蕉の辻」周辺の人通りはまばらであり, 認知度 も低下している。

戦災復興事業によって再編された街路は, 藩政時代 の区割りを基盤にしているものの，直進性や流動性を 重視したものとなった。そのため，大きく曲げられた り，新たに新設された箇所も多い。文化的側面を重視 した街並み保存の観点から見れば，多くの問題点が指 摘されるであろうが，このような構造変容が戦後にお ける仙台市の急速な発展に大きく寄与したことは明ら かである。

以上のような歴史的経緯を持つ仙台市の街並みを， 現在の人々はどのように見ているのか，という点を明 らかにするために, 山形大学の学生 21 名に,「仙台を 意識する景観」というテーマを与え，写真を撮らせた。 その結果，大半の学生が「仙台駅」(17 名)，「伊達正宗 像」(17 名)，「アーケード」(16 名)，「ケヤキ並木」(15 名）の写真を撮っておうり，仙台市のイメージが定着し ていることが分かった。しかしながら，「広瀬川」(9名) や「その他の自然景観」(4 名) を撮る学生は少なく, 「碑」や「親水空間」を撮った学生はそれぞれ 3 名と 2 名にとどまった。反面，露店商や路上パフォーマンス
を撮った学生が 7 名抢り，「見慣れないもの」 市」 $\rightarrow$ 「仙台」というイメージも同時に形成されてい ることが推測される。

仙台市は,「杜の都の風土を育む景観条例」を 1995 年 に制定した。そこには住民と事業者が景観形成に関す る意見を出し合い，行政はそれらを調整して計画を具 現化するための努力をするという景観三原則がうたわ れている。また，景観三原則に基づいて景観形成を推 進していくための景観 7 方策もそれぞれ実施されてい る。景観 7 方策では, 住民や事業者の自主性を高め, そ れを支援する方策が多くとられているのが特徴であ る。

現在，都市で活動する人々の多くは，それぞれの目 的に合わせて街を見ており，景観にはほとんど無関心 である。仙台市の景観計画は，このような現状を否定 し，景観に対する彼らの意識を高めていこうとするも のであり，自主性に基づく理想的な景観形成を念頭に 置いている。しかしながら，仙台市が大都市になれば なるほど，同市で活動するすべて人及に景観に対する 高い関心を要求することは困難になる。景観に対して それほど大きな関心を持っていない人々の空間認識 が，当該地に対する一般的なイメージになりつつある 昨今の状況を見ると，行政が住民や来訪者の活動目的 に合わせた分かりやすい景観を積極的に提示し, 彼ら の空間認識を誘導していくことも考慮すべきである。 当該地の存在意義を広くアピールするという景観の持 つ本来の意味からすれば，そのような景観計画も今後 の一つの方向性といえるかもしれない。

\section{地方自治体における政策形成の仕組みづくり}

\section{金安岩男（慶應大）}

\section{Iwao KANEYASU: Framework for Policymaking in the Local Government}

近年わが国の地方自治体において, 自治体内に研究 所を設置する動きが顕著になってきた。その背景には， 自治体の予算減少，職員の政策立案能力の強化，そし て 2000 年に施行された通称地方分権一括法による地 方分権の促進などがある。この発表では, 地方自治体 における政策形成の仕組みづくりをテーマとし，いわ ゆる自治体シンクタンクについて，横須賀市都市政策 研究所を事例にして検討を加える。発表者は研究所の 設立ならびに初代所長として参画したが，その経験に もとづき報告する。
自治体シンクタンクとは，自治体と密接に関係を持 つ非営利型の組織であり, 調査分析, 政策立案, 評価 などを行う政策研究組織である。その種類としては, 研 修所型，自治体内設置型 (企画部門型), 財団型, 第 3 セクター型などがあり，横須賀市の場合は自治体内設 置型に該当する。

1993 年 6 月に沢田秀男市長が誕生（3 期務め，2005 年に退任) し, 企画調整部企画調整課の設置, 総合計 画の策定作業（1995 年度から 1997 年度）などと共に， 專門委員制度の充実，政策立案に主任・副主任クラス 
を 100 名任命, 計画策定（調査分析，市民参画，職員 協働など）など政策面を充実させてきた。さらに，政 策研究事業を 1998 年度から始好など, 公共施設の基 本設計，イベント開催，パートナーシップ研究会，市 民活動支援研究会なども実施してきた。加えて，『政策 研究よこすか』を 1998 年度に創刊し，世間に広報して きた。当時の若手・中堅職員は政策立案のプロセスに 賛同し, その後, 継続的活動を重視して, 研究所の設 立に向けて予算要求を出し続けた結果, 沢田市長（当 時)の了解を得ることができた。2001 年 12 月に，市長 の定例記者会見に引き続き, 研究所設立の記者発表を 行った。2002 年 4 月に横須賀市都市政策研究所が設立 され, 初代所長に慶應大の金安岩男が指名され, 4 年間 （2002-2006）にわたり研究所の運営にあたった。

2001 年 12 月に金安が理念を作成し，記者発表の際 に公表したが，ビジョナリーカンパニーの考え方にも あるとおり，組織運営において，コアとなる理念は重
要である。研究所は地方行政をテーマにして, 創造的 破壊と知的統合を行い，学術と実践の融合をはかると ともに，自治体職員の政策立案能力を高めることを理 念とした。

研究所は, 出版, 論文, 学会・シンポジウム, 受賞 (法政大学地域政策賞優秀賞), 視察数, 県内一の影響, 若手研究者の活動の場の提供, 職員大学院派遣者の所 属場所, 自発的な大学院で学習, 庁内での政策検討な ぞ，効果を発揮している。地理学者は，地域に関する 知識, プロジェクト推進, 全体を俯瞰するバランス感 覚などを有しているので，その特色を活かすことがで きる。今後の課題は, 人材の確保, 独立性の確保, 研 究交流, 協働研究, 研究成果の活用などである。課題 を克服するためには，トップの理解，見識，関係者の 熱意と志, ビジョンとパッション, 担当者の向上心, 実 力，変化への対応（組織・人）などが要求される。

\section{地方都市再開発の 1990 年前後の比較と問題の考察}

\section{1. 問題の所在と限定}

我が国の都市整備史上特筆すべきは，1919 年 (大正 8）の「都市計画法」，1946 年「特別都市計画法（戦災 復興 : 27,900 ha)」制定の他, 1969 年の「都市再開発法」 の制定などであろう。ここでは，都市再開発法制定以 降に扮ける, 地方都心部の顕著な商業・経済力衰退に 対する都市整備の関係を解明することを目的としてい る。実態を地方都市整備と中央大都市整備の別によっ て, 1990 年以前と以降の比較を試みるものである。資 料は「日本都市再開発」の事業完了地区の各号による。 資料の加工・集計に基づく。特に日本的都市再開発の 継続如何, 地方都市における都市再開発の継続如何, お よびそのもたらす効果を明らかにしたい。

地方都市概念については, 石水照雄 (1973), 渡辺良 雄 (1989), 高津斌彰（1990）を参考にして，3 大都市 圏以外の地域圏の都市すべてを地方都市と規定する。 それは，中央都市：国家都市：国家的都市システムを もつ都市との対概念としての地方都市の性格，つまり 国家潅力による特別の立法的規定を受けない都市であ ることによる。都市再開発概念については, R. Murphy の概念もあるが, 69 年の都市再開発法に指定する市街 地再開発事業に当たるものとする。

2. 考察

都市規模（人口）別再開発件数は，60万人以上都市

\section{高 津 斌 彰（新潟大）}

に集中がみられ, 1979 年以前には 20 40 万人都市, 40 〜 60 万人都市に次いでトップ件数から 3 位の位置に あったものが，84〜89 年段階では 40〜 60 万人規模都 市を抜いて 2 位となり, 95〜99 年段階ではトップを占 めている。明らかに 80〜84 年以降 3 5 万人規模層は 各 5 年間 10 件未満, 3 万人以下層では, 各 5 年間 3 件 未満と低迷したままである。

これを都道府県別にみると, (1) 東京都, 大阪府に高 く,とりわけ, 25 年間では 59 件を数える東京都が目立 つ，とりわけ近年の 95〜99 年に倍増している。なお， (2) 埼玉, 千葉, 神奈川各県など 3 大都市圏の東京圏に 集中している。(3) 兵庫県は神戸市を中心として，40 件, 70 年代前半当初から, 毎期 10 件前後で展開し, 大 阪府が同 30 件を数え, やはり 90 年代後期で前半の 4 倍増で 8 件, よって神奈川県の 25 件, 愛知県の 17 件 となる 3 大都市圏に都市再開発の集中がみられる。埼 玉県 (21), 千葉県 (17) は, 神奈川県 (25) と並んで 比較的高い。3 大都市圈の東京圈にはいる。(3) 大都市 圏内をみると，東京都区部（46）は圧倒的である。特 に 90 年代後半の東京湾岸埋めたて, 丸の内 project な どが華々しく動きだした。大阪市 (23), 神戸市 (14), 横浜市 (7) が続く。(4) 広域都市圏では, 札幌, 仙台, 広島, 福岡市など地方中心都市機能を擁する北海道, 宮 城, 広島, 福岡県では, 北海道 (28)を筆頭に愛知, 神 
奈川を上回っている。宮城・福岡 (各 12), 広島 (6) は, 特に高くは見えにくい。地方都市圈都市では山形(17)， 群馬（13），富山（18），石川（10），長野 (10)，静岡 (18), 岡山（11）の如く再開発の比較的盛んな道県も ある。地方都市圈では 76 件で, 各期にまんべんなく進 捗した。そして，トップを占めるのは東京都であり，神 奈川, 愛知, 兵庫, 埼玉県で増加傾向がみられ, 大阪 府は減少している。広域都市圈の北海道, 宮城, 広島, 福岡各県では特に顕著な伸びが見られない。

3. 総括

中央都市二国家都市と地方都市 (含む広域都市圏) 圏 の格差が確認可能である。(1). 1975 年以前から始まる 都市再開発は地方都市のパフォーマンスの中央 (国家)
都市と変わらなかった。(2) その地方都市が 1990 年以 降の都市再開発事業実施に扔いて，相対的なシェアを 縮小し,活力がなくなった。(3) 地方都市圈における札 幌市・北海道を除く, 広域都市圈都市を含め, 実施件 数の減少が認められる。(4) 3 大都市圏内都市の都市 再開発件数の拡大がある。その要因には，(5) 県庁・市 役所における都市作りシンポジウム，ワークショップ 開催等に於ける，都市再開発の趣旨：目標の変化（老 朽市街地修復 $\rightarrow$ 商業活性化) があげられる。(6) 地方都 市の疲弊，中心商店街疲弊 $\rightarrow$ (7) 中央（国家）都市の集 中活性化（経済・財政・金融再生の装置化=市街地活 性化法・各種都市再開発の改訂）等があげられよう。

\section{福島県安達太良連峰山稜部における植生景観 (2) 一山頂現象と植生分布一}

\section{1.はじめに}

安達太良連峰は, 標高 $1,700 \mathrm{~m}$ 前後で, 南北に伸びる 火山群である。この峰々のうち, 沼ノ平火口周辺の稜 線に扔いて, 高山植物群落が植被階状土やしっ添状植 生を形成している(杉山，2006)。このような植生景観 は，本来，より高緯度，高所の高山帯で見られるもの であり, 安達太良連峰という東北地方南部の $1,700 \mathrm{~m}$ 峰では通常見られない。中でも，しっぽ状植生は，こ のような低緯度かつ低所で報告されていない。そのた め, 安達太良連峰山稜部の植生景観は, 低所, 低緯度 における高山带的植生景観の成因論を進める上で, 重 要な事例となるであろう。発表者らは，この安達太良 連峰山稜部における植生景観の成立要因を解明す心゙ く, 研究を進めている。まず, その第一段階として, 植 生景観と地形を重放ることで, 植生が山頂効果と火山 攪乱を受けているであろうと推定した（杉山，2006）。 今回, この推定を受けて, 沼ノ平周辺稜線に働く山頂 現象を明らかにするため, 調查を行った。

\section{2. 調查方法}

今回, 山頂現象の原因とされる強風と, 不均等な積 雪分布（小泉，1993）を調べるため，（1）偏形樹調査, (2) 積雪深調査を行った。（1）偏形樹の研究はすでに 行われている(小野寺, 1963; Onodera, 1964)ものの, 調査範囲が不十分，かつ，偏形グレードの考察を行っ ていないため，今回，改めて調査することとした。偏 形グレードは, Yoshino(1973)を参考に設定した。(2) 2006 年 3 月 7 日, 稜線部の任意の地点, および, 稜線 を横断するように側線を設け，積雪深を測定した。以

\section{杉山 悠然（北海道大・院）・渡邊 雅彦}

上のようにして収集したデー夕を，それぞれ植生図と 地形図に重初て評価した。

3. 調查結果と考察

（1）偏形樹の分布, 偏形方向, グレード

風向は, 西〜北の傾向を示してお抢よそ揃っており， 先行研究 (小野寺, 1963; Onodera，1964) と同じ傾向 を示しており，季節風の影響を確認できた。また，グ レードに関して, 山稜部でグレード $3 \sim 4$, 稜線から下

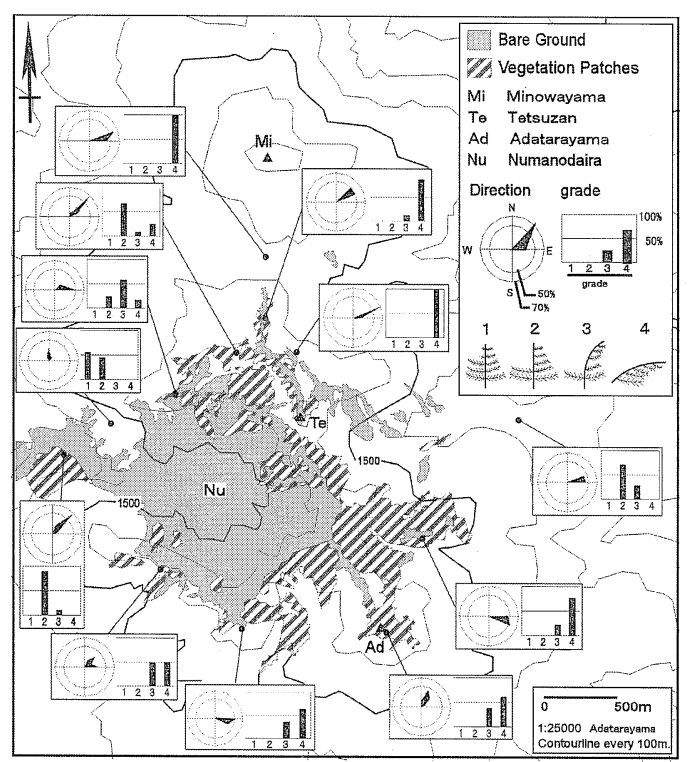

四 
るとグレード 1〜2 となっており,稜線部で風が強いこ とを確認できた。

（2）稜線を横断する積雪深分布

稜線部で 10〜 30 cm, 斜面部分で 40～100 cm, 篗地 の多いところで $300 \mathrm{~cm}$ 近くなっていた。表層の雪質 は，稜線部でえびのしっぽやウインドクラスト，斜面 部で柔らかい雪質へと変化していた。この二点から,雪 は稜線部で吹き払らわれ，斜面部で吹き溜まるようで ある。加えて，積雪深 10〜 30 cm の地域では裸地，40 $\mathrm{cm}$ 以上の地域では連続的な植生が見られた。つまり， 積雪深に対応した植生分布となっていることを確認で きた。

以上より, 安達太良連峰の山稜部において, 1. 強風 地域であること，2. 吹き払い，吹き溜まりにより不均 等な積雪分布を呈すること，3. 積雪深に応じて植生が 分布していることが確認できた。つまり, 安達太良連 峰山稜部汸ける山頂現象は, 季節風効果 (山頂効果) により生じたものである。

\section{栗駒山のオオシラビソ小林分はいつ成立したのか？}

\section{若松 伸彦（横浜国立大・院）。池田重人（森林総合研究所）。 河野樹一郎（京都府立大。院）}

一部の東北日本の山岳では，亚高山性針葉樹林が発 達するのに十分な温度領域を有する標高带にオオシラ ビソ林がパッチ状にしか分布していない。栗駒山にお けるオオシラビソの分布は西稜線の一角にある秣岳 （まぐさだけ）に小林分がみられるのみである。また， 近辺の山にも生育しておらず，最も近い分布地でも $100 \mathrm{~km}$ 前後の距離を隔てている。栗駒山オオシラビソ 林は分布上のこうした特徴から，日本列島におけるオ オシラビソの地理的変遷を考えるうえで重要な林分で あると考光られる。本研究は栗駒山のオオシラビソ小 林分がいつから存在していたのかを,土壌層序の記載, 花粉分析，植物珪酸体分析，年輪解析などをおこない 明らかにすることを目的とした。

オオシラビソ林内の土壌厚は厚さ約 $20 \mathrm{~cm}$ で, $\mathrm{AD} 915$ 年に降下した十和田 $\mathrm{a}$ 火山灰 (To-a) に対比さ れるテフラ層が，腐植層㧍よび腐植を含むローム層内 の岩塊層にかなり近い位置に存在する地点が一部みら れた。このような地点は To-a 降下当時, 植被が薄い状 態であった可能性が高い。

オオシラビソ林分脇の湿原において採取した土畩試 料は表層より深さ $118 \mathrm{~cm}$ までの泥炭質堆積物試料中 には 4 枚のテフラ層が挟在しており，上位より Mgs 1 〜Mgs 4 とした。このうち Mgs1 は To-a に対比され たが, 他の 3 枚のテフラの給源や噴出年代は現在のと ころ不明である。花粉分析の結果, モミ属花粉の出現 率は表層部でも小さく $2 \%$ 程度以下であり，ブナ属等 の広葉樹花粉やスギ属花粉の割合が大きかった。これ は，林分の花粉生産量が小さいことや，林分が山岳上 部の尾根部に位置するため下方からの飛来花粉の影響 を受けやすいことなどが原因として考光られる。それ でも，出現率は小さいながら表層から $\mathrm{Mga}-2$ 層下部
まではモミ属花粉が連続して検出されたことから，小 面積の林分はこの時代から周囲に生育していた可能性 が高い。モミ属花粉の量は To-a 層上位では下位に比 べて増加している傾向がみられた。 Mgs-2 と Mgs-3 の中間までは広葉樹の花粉が圧倒的に優勢であるが, さらに下部ではモミ属とトウヒ属を主とする針葉樹花 粉が大きな割合を占めていた。これらの針葉樹は最終 氷期の名残を示すものと考光られるが，今後 ${ }^{14} \mathrm{C}$ 年代 の測定などによって年代を明らかにする必要があると 考えられる。

オオシラビソ林内 2 地点の土壤内におけるササ珪酸 体の量は，両地点ともに To-a 直上の層位内でその前 後の層位と比較して急減している。また，この急減す る層準を挟んだ上位と下位を比較しても下位ではササ 珪酸体の量が少ない傾向にあった。このような事実は， オオシラビソ林内では火山灰の降灰層準でササが少な く，その後現在にかけて再びササが増加した可能性が 考元られる。しかしササ珪酸体の量から生息していた ササの量を推定するためには堆積速度を考慮する必要 があり今後さらなる検討が必要である。

オオシラビソ林内の分布において年輪解析をおこ なった結果，200 年より若い個体のみで形成された林 分は確認できず，ここ 200 年以内に新たに林分の拡大 はおこなわれていないと推測される。

栗駒山秣岳のオオシラビソ林は To-a 降下以前の数 千年前には付近に分布していたと考元られる。その一 方でTo-a 降下直後に分布域ないしは密度を増加させ た可能性があるものの, 過去 200 年以内には分布域の 拡大を扢こなった形跡はない。またササの珪酸体量は To-a の直上の層位で急減し，その更に上の層位で急 増しており，オオシラビソの分布拡大を考える上で注 
目される事実である。

\section{阿武隈高地仙台平ドリーネにおける蘚苔類の分布と生育環境}

\section{乙幡 康之（法政大・院）}

福島県阿武隈高地の仙台平は，中生代ジュラ紀とさ れている滝根層群の石灰岩が, 白业紀前半の花崗岩の 貫入によって大理石化している。仙台平は大理石から なる台地で，カルスト地形が発達している。ドリーネ 内は大理石のピナクルが分布し，その表面には，数多 くの蘚苔類が生育している。仙台平ドリーネの自然環 境を明らかにし，大理石の表面に生育する蘚苔類の生 態，及びその分布要因を考察することを目的にした。

調査方法は，ドリーネを N-S と W-E 方向の断面に 沿って, 生育する蘚苔類を同定し, 蘚苔類の種別の生 育環境を明らかにした。蘚苔類の生育するピナクルの 平均傾斜と地表からの生育高度を計測した。ドリーネ 内の冬季の積雪深を測定し，融雪時期を把握した。共 存する草本と樹木の調査を行った。さらにまたドリー ネの春季の気象钼測もおこなった。

調査の結果，出現した蘚苔類は 30 種であり，そのう ち好石扊岩性の種はわずか 6 種であった。好石扊岩性 の蘚苔類は劣悪な環境即ち乾燥し, かつ中性〜弱アル カリの母岩の上に生育できる種である。好石扊岩性の 蘚苔類がこのドリーネ内の出現が少ないということ は，ドリーネ内が多湿であり好環境であると考えられ る。そのことから好石灰岩性の蘚苔類以外の種も大理 石上に生育することができると考えた。ドリーネには 多くの樹木が生育し, 適度な日照環境を形成している。 しかし林床は冬季の積雪以外はササ類や野草で覆われ るため，蘚苔類が林床に生育するのは困難であると考 えた。

\section{丘陵地谷頭部の土層構成が降雨流出機構に及ぼす影響}

流域内の水循環のうち，谷頭部での水文流出過程の 部分については，谷頭部の特徴をとらえて水文地形学 的な視点で解析する必要性がある。谷頭部の特徵とは, 例えば土層の不均一性による地中水の流路・流速の変 化が起こること, 谷頭部の水や土が集積しやすい地形 が水の流れに影響すること，パイプが発達しており崩 壊等の地形変化の出発点となりやすいことなどであ る。本研究では，水文地形学的な視点に基づき，森林 域の最初の流出点である谷頭部での土層別の流出観測
蘚苔類の分布は，オオギボウシゴケモドキ Anomodon giraldii, キンモウヤノネゴケ Bryhnia trichomitria, ヒモヒツジゴケBrachythecium helminthocladum などの匍匐型の種が優占する。これ らの種は生育傾斜，生育高度に幅があるため，ピナク ルの高度が違うところでも出現している。アッブサゴ ケ Homalothecium laevisetum は N-S 断面の南向き 斜面卓越する。最も優先するオオギボウシゴケモドキ は，N-S 断面の北向き斜面で最も卓越する。ここはド リーネ内で最も乾燥していると思われる場所である。 W-E断面のドリーネ底では,キンモウヤノネゴケが卓 越する。オオトラノオゴケ Thamnobryum subseriatum の分布は広域にわたり，地面から比較的低い位置に多 く出現する。ネズミノオゴケ Myuroclada maximoviczii も同様に地面から比較的低い位置に出現し，ドリーネ 底から北向き傾斜と西向き傾斜に分布する。

ドリーネ内では最低気温時に。ドリーネ底はドリー ネ上部より約 $2.0^{\circ} \mathrm{C}$ 気温が低く, 湿度は約 $5.0 \%$ ドリー 不底のほうが高い。このことからピナクルが分布する ドリーネ底は蘚苔類にとつて湿度が高く，好環境であ ることがわかる。

積雪深はドリーネ上端斜面で約 $2 \mathrm{~m}$ である。冬季, 蘚苔類は積雪下に生育し, 積雪の影響は少ないと考え られる。しかし融雪時には，急傾斜な北向き斜面（傾 斜 $25^{\circ} \sim 30^{\circ}$ ) にあるピナクル表面で, 蘚類と共に大理石 粒子の剥離が生じていることがわかった。

古田 智弘（東北大。院）。後藤 光龟（東北大）

と微地形観察をもとに，そこに発達するパイプ流の形 成素過程や蒸発散を考慮したモデル解析から，その流 出機構を調べた。観測流域は仙台市太白山自然観察の 森で，丘陵地であり，基岩の地質は砂岩である。集水 面積は $1,004.7 \mathrm{~m}^{2}$ であり，横断面方向に広い流域であ る。集水域の中央には谷頭凹地が存在する。流出発生 点では, $\mathrm{B}$ 層, $\mathrm{BC}$ 層が薄くなり, $\mathrm{A}$ 層, $\mathrm{AB}$ 層が厚く, $\mathrm{AB}$ 層は最大 $52 \mathrm{~cm}$ に達し, 基岩が $\mathrm{AB}$ 層の直下に存 在する場合もある。流出発生点から上流に $2 \mathrm{~m}$ の地点 
では， $\mathrm{AB}$ 層の下に $\mathrm{B}$ 層，C 層が存在しその厚さは計 約 $120 \mathrm{~cm}$ に達した。流出発生点から上流に $12 \mathrm{~m}$ の谷 頭凹地では，B 層，C 層は $200 \mathrm{~cm}$ 以上であった。流出 は梅雨期 (7月 1 日 0 時- 8 月 4 日 1 時) と秋雨期 (9月 28 日 23 時-11月 1 日 0 時）飞多く発生し，夏期（8月 4 日 1 時-9 月 28 日 23 時）は降水が存在しても流出は 観測誤差の範囲外では発生せず，渴水状態であった。

流出結果について 1 段 2 流出タンクモデルを用いた 解析を行った。強雨時流出発生域からの流出を $\mathrm{Q}_{\mathrm{k}}$, パ イプ P1 からの流出を $\mathrm{Q}_{\mathrm{P} 1}, \mathrm{~A}$ 層からの流出を $\mathrm{Q}_{\mathrm{A}}, \mathrm{AB}$ 層， $\mathrm{B}$ 層， $\mathrm{BC}$ 層からの流出を $\mathrm{Q}_{\mathrm{ABC}}$ ，基岩からの流出 (パイプ P2，パイプ $\mathrm{P} 3$ からの流出を含む) を $\mathrm{Q}_{\mathrm{R}}$ とし た。実測值 $\mathrm{Q}_{\mathrm{K}}+\mathrm{Q}_{\mathrm{P} 1}+\mathrm{Q}_{\mathrm{A}}+\mathrm{Q}_{\mathrm{ABC}}$ をタンクモデルの $\mathrm{Q}_{12}$ に, 実測值 $\mathrm{Q}_{\mathrm{R}}$ をタンクデルの $\mathrm{Q}_{11}$ に対応させた。モ デル計算時に流出率は観測された值とほぼ等しくなる ように設定し，実測值との残差平方和が最小になるよ うにパラメータを決定した。遮断蒸発量と蒸発散量は, 近藤ら（1992）と仙台管区気象台の月蒸散量デー夕か ら推定した。タンクの係数については蒸発散ありの流 出係数 $\alpha$ は蒸発散無しの拈上そ半分，浸透係数 $\beta$ は $1 / 10$, タンクの高さは約 3 倍と算出された。蒸発散無
しモデルでは，夏季も $\mathrm{S}_{1}$ が $\mathrm{L}_{11}$ の值を超えて，流出が 算定された。しかし，蒸発散ありモデルでは， $\mathrm{L}_{11}$ の值 が引き上げられたことにより，貯留 $\mathrm{S}_{1}$ の変動が緩や かになり，夏期の流出はなくなって流出の再現性が向 上し, $\mathrm{S}_{1}$ のグラフが地下水位のグラフに近づくことで 貯留高の再現性も改善した。ただし，降水の 1 イベン トを取り出したところ計算值 $\mathrm{Q}_{12}$ は実測値に比べて ピーク前後の流出量変動が緩やかであり，その再現性 は不十分であった。

一方，気温と水温の経時変化についても，2005 年 7 月25日から 29 日まで観測を行った。その結果， $Q_{k}$, $\mathrm{Q}_{\mathrm{P} 1}, \mathrm{Q}_{\mathrm{R}}$ のいずれについても水温の急激な低下が見ら れ，とくに $\mathrm{Q}_{\mathrm{P} 1}$ では 30 分で約 $7^{\circ} \mathrm{C}$ とくに急激で あった。温度の急激な変化の前に地下水位も不連続な 上昇を示しており，土層のみを経由した水と基岩を経 由した水が混合したと考えられる。降雨終了後の流出 減少は標高の高い $\mathrm{Q}_{\mathrm{K}}$ から始まり，基盤の地中水の減 少に時間がかかることが確認された。今後は降水と上 流の基盤からの地中水の供給を区別したモデルの改善 が必要である。

\title{
荒川中流部における近・現代洪水時の高水位変動と河床微地形変化
}

\author{
石田武・田村 俊和・菊地隆男（立正大）。 \\ 宮下 香織（立正大・院）・高村弘毅（立正大）
Takeshi ISHIDA, Toshikazu TAMURA, Takao KIKUCHI, Kaori MIYASHITA and Hiroki TAKAMURA : Development of River-bed and River-side
Micro-landforms in the Modern Flood-level Lowering Stage in Mid-Arakawa, Central Japan

荒川中流部では，江戸時代からの河道付け替えを含 む長年の改修の結果，幅広い河川敷（堤外地）が形成 された。このため, 流路の変遷・固定化や中洲の安定 化などの扇状地特有の河床微地形変化が堤外地によく とどめられている。一方，明治後期以降，砂利採取に よる河床低下やダムによる流量調節が行われるように なると, 洪水時の高水位レベルが低下してきた。本研 究では, 近・現代以降に発生した洪水を取り上げ, 洪 水時の高水位変動と河床微地形変化との関係について 検討する。

調查地は，微地形の配列からいくつかのゾーンに区 分される。明戸地区 (A) は，相対的に低く平坦な $\mathrm{AI}$ (コナラ,クヌギなどの亜高木が点在する疎林と，低木 や草本のみから成る部分とがある), AI と高さ数 $\mathrm{m}$ の
崖を隔てた幅 100〜120 m ほどの AII（よく成長したコ ナラなどに覆われている)，現在の本流に沿う，幅 10 〜 40 m の AIII（植生を欠く）に区分される。明戸地区 の約 $4 \mathrm{~km}$ 下流に位置する野鳥の森公園 $(\mathrm{Y})$ は，比高 $1 \mathrm{~m}$ 内外の起伏があり, 最新の氾濫堆積物 (減水時の懸 濁物質）を母材として土壌断面が発達している YI, 比 較的平坦で，細粒物質をほとんど欠き，洪水時に流送 された砂が地表まで露出し, 樹林が発達していない YII，現在も冠水するYIII（現河床）に区分される。 空中写真判読の結果, AI に A (1) 〜 A (3), AIII に A (4), YI $に Y(1), Y I I に Y(2) \sim Y(4), Y I I I に Y$ (5) の流 路跡が認められた。空中写真に示された氾濫堆積物の 堆積状況から，これらの流路跡に洪水流が流入した履 歴を調べた（表 1 ）。河床低下が少なく，流量調節がほ 
表 1 旧流路への洪水流の流入状況

\begin{tabular}{|c|c|c|c|c|c|c|c|c|}
\hline \multirow{3}{*}{ 地形区 } & \multirow{3}{*}{ 旧流路 } & \multicolumn{7}{|c|}{ 洪水発生年 } \\
\hline & & 1910 & 1938 & 1947 & 1974 & 1982 & 1999 & 2002 \\
\hline & & (M43) & (S13) & (S22) & (S49) & (S57) & (H11) & (H14) \\
\hline \multirow{3}{*}{ AI } & A (1) & $(\bigcirc)$ & $(\bigcirc)$ & $\bigcirc$ & $\times$ & $x$ & $\times$ & $\times$ \\
\hline & A (2) & $(\bigcirc)$ & $(\bigcirc)$ & O & $\triangle$ & $\triangle$ & $\cdot(\triangle)$ & $(x)$ \\
\hline & A (3) & $(\bigcirc)$ & $(\bigcirc)$ & $\bigcirc$ & O & O & $(\bigcirc)$ & $(x)$ \\
\hline AIII & A (4) & $(\bigcirc)$ & $(\bigcirc)$ & O & O & $x$ & $\times$ & $(x)$ \\
\hline YI & Y (1) & $(\bigcirc)$ & $(\bigcirc)$ & $\triangle$ & $x$ & $x$ & $x$ & $x$ \\
\hline \multirow{3}{*}{ YII } & Y (2) & $(\bigcirc)$ & $(\bigcirc)$ & O & $\times$ & $x$ & $x$ & $\times$ \\
\hline & Y (3) & $(\bigcirc)$ & (O) & 0 & $\times$ & $x$ & $x$ & $\times$ \\
\hline & $\mathrm{Y}$ (4) & $(\bigcirc)$ & $(\bigcirc)$ & O & $\times$ & $\times$ & $x$ & $\times$ \\
\hline YIII & Y (5) & $(\bigcirc)$ & $(\bigcirc)$ & ○ & ○ & O & O & O \\
\hline \multirow[t]{2}{*}{ 水位 } & 寄居 & $?$ & 10.10 & 9.20 & 4.15 & 2.95 & ? & ? \\
\hline & 熊谷 & $?$ & $?$ & $?$ & 3.76 & 4.19 & 5.33 & 4.07 \\
\hline
\end{tabular}

○：流路を流下した。 水位記録より推定したもの。

とんど行われていなかった，カスリン台風(1947 年)以 前は，堤外地全体にわたって洪水流が流れていたこと がわかる(ただし，AII には流入していない)。それ以 後も，上流側での河床低下の影響が少ない明戸地区 （A）では，AIゾーンへの洪水流の流入が続いている。
一方, 1960 年代に河床低下が顕在化した野鳥の森公園 （Y）では，1974 年以降，現河床（YIII）以外への洪水 流の流入はほとんどみられない。このような洪水流の 流入頻度の差が，各ゾーンの表層堆積物の層相・層厚 や土壌発達に違いをもたらしたと考えられる。

\section{鹿児島県志布志砂丘にみられるウォッシュオーバー堆積物}

\section{伊 藤 晶 文（鹿児島大）}

\section{Akifumi ITO: The Morphological Responses to Extreme Storms} in Shibushi Sand Dune Field, Kagoshima

鹿児島県志布志湾には，南東方向に開けた長さ約 16 $\mathrm{km}$ の砂質海岸が広がり, 海岸線から約 $1.5 \mathrm{~km}$ の間に 海岸砂丘が発達している。ここでは, 2004 年の台風 16 号および 18 号の通過後に, 遡上波による崖の形成に加 えて, 従来報告例がほとんどない,オーバーウォッシュ の発生が原因とみられる砂丘の地形変化が認められ た。そこで, 本研究では, 現地踏査, 水準測量, 堆積 物の観察抒よび粒度分析を行い，遡上波とオーバー ウォッシュによる地形変化，特にウォッシュオーバー 堆積物の分布と特徵を明らかにし，鹿児島県志布志砂 丘における異常暴浪時の地形形成作用を考察した。

調査地域では, 海側から順に, 前浜, 後浜, 砂丘と
いう地形配列が共通して認められる。台風通過前に存 在していた草本植生に被覆される砂丘の前斜面は，台 風接近時の遡上波によって消失し，代わりに $1 \sim 2 \mathrm{~m}$ 程度の崖が形成された。今回の調査地点で計測した平 均海面と砂丘崖頂部の比高は, 4.5 5.3 $\mathrm{m}$ である。砂丘 は一部の地域を除いて，植生の被覆状況により，海側 から順に，砂丘 (草本带) と砂丘（海岸林）とに区分 される。通常時には風による砂の移動，堆積が活発に 起きている砂丘 (草本帯) では，オーバーウォッシュ による植生破壞や地表面の平坦化，流木やプラスチッ ク製品などのゴミおよび平均粒径 3〜 $5 \mathrm{~cm}$ の軽石砂 の部分的な集積が認められた。一部の砂丘崖では，軽 
石礘抢よびゴミの密集層と砂層の互層が観察された。 通常時には砂の移動が浪とんどなく，非常に安定して いる砂丘 (海岸林) では，オーバーウォッシュにより 運ばれた砂の堆積がほぼ全域で確認された。

砂丘（海岸林）に分布するウォッシュオーバー堆積 物は，白色～灰白色の砂を主体とし，混入物はほとん ぞない。海岸線から約 $190 \mathrm{~m}$ 内陸まで分布する場所も ある。堆積物の厚さは, 最も厚いところで $30 \mathrm{~cm}$ を超 えるが，多くの場所では $10 \mathrm{~cm}$ 以下であり，陸側に向 かって薄くなる傾向を持つ。厚く堆積する地点では, 平 行ラミナが観察された。最頻粒径は 1.5 1.75中付近に あり，4申より粗粒分についての平均粒径と淘汰度は， それぞれ $1.339 〜 1.711 \phi ， 0.580 \sim 0.722$ であった。これ らの值は，台風通過前に存在していた砂丘の前斜面に 相当する場所に位置し，現在は風成堆積が卓越する後 浜の堆積物と, 砂丘 (草本帯) の堆積物とが示す值に 近い。この事実は，砂丘（海岸林）に分布するウォッ
シュオーバー堆積物の主な供給源が，砂丘の前斜面ま たは砂丘 (草本帯) であることを示す。また，ウォッ シュオーバー堆積物の下位の堆積物の粒度組成も良く 似ていることから，今回と同様のオーバーウォッシュ が過去にも生じている可能性が高い。

今回の調查結果から，異常暴浪時における志布志砂 丘の地形形成作用は，以下のようにまとめられる。異 常暴浪時には，砂丘の前斜面は遡上波による侵食で消 失し，代わりに砂丘崖が形成される。オーバーウォッ シュの発生により，砂丘（草本帯）では植生破壞と面 状侵食による平坦化が生じる。さらに,オーバーウォッ シュにより運ばれた軽石碟や流木，ゴミが残留堆積物 として，部分的に集積する。陸側の砂丘（海岸林）に は，砂丘の前斜面，あるいは砂丘 (草本帯) で削られ た砂が運ばれ堆積する。以上の地形形成作用は，過去 にも生じている可能性が高く，志布志砂丘の形成に大 きな役割を果たしていると考えられる。

\section{大学キャンパス内コナラ林における地温日変化（序報）}

菊地立（東北学院大）。吉田 勇太（(株）日本旅行）

近年里山に関心が集まっている。しかし，気候学分 野では里山を含め森林に関する調査が少なく，林内気 候の詳細はわからないことが多いことから，今回大学 構内にあるコナラ林を利用して地温を中心とした微気 候調查を試みた。

調查地域は海抜 $70 \mathrm{~m}$ 前後の丘陵で，北向きの斜面 を数本の小さな谷が刻んでいる。40 年前の空中写真に よればササが地表を覆い高木はみられないが，現在は 樹高 $20 \mathrm{~m}$ に近い密集したコナラ林となっている。観 測は，小さな谷を東西に横断するラインに沿う５地点 (西側少ら尾根 (1), 斜面 (1), 谷底, 斜面 (2), 尾根 (2)) において, 深さ 1, 3, 9, $27 \mathrm{~cm}$ の地温の自記記録 (15 分 間隔）を中心として，これにほほ 2 週間毎に晴天日を 選んで全天写真（魚眼レンズ）による天空率測定と照 度測定を加えた。また，尾根 (1)では地上 $10,250 \mathrm{~cm}$ の 気温を 15 分間隔で自記記録した。

5 月中旬から 12 月中旬までの観測から，次のような 結果が得られた。

（1）深度別に地温を見ると，どの季節でも $1,3,9$ $\mathrm{cm}$ に扔いては明瞭な日変化が見られ, 深くなるにつ れて日較差は小さく位相が遅れていく。27 cm の深さ では日変化が見られない。浅層でも地温の日較差は裸

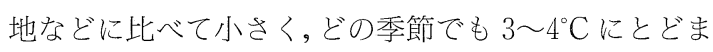
る。連続晴天日の時刻別平均值で日変化パターンを比
較すると，季節の進行に応じて大きく変化する。6〜8 月は深くなるにつれて温度が低いことに加え，午前の 温度上昇が比較的緩やかであるのに対して，10１1月 は深くなるにつれて温度が高いことと午前中の温度上 昇が相対的に急で，最高值の出現が早い点で前者と異 なる。

（2）高度・深度別日平均地温・気温の季節推移を見 ると，5〜8月は上部ほど温度が高く熱の流れの方向は 上から下への受熱型であり，10～12 月は逆に放熱型と なった。9月下旬に両者が切り替わる。

（3）地温日変化パターンは，夏（7月）においては 地点間の違いが小さく, 斜面 (2) $1 \mathrm{~cm}$ が 14 時前後 に一時的昇温を示すことと尾根 (2) が常に低温である ことの他には,どの深さにおいても温度差 $1^{\circ} \mathrm{C}$ 程度に 収まる。一方冬 (12月)に打いては地点によって大き な違いがあり, 尾根地点同士で比較すると尾根 (1) は日 変化が大きく尾根 (2) は小さいこと, 斜面同士で比較す ると斜面 (1) が日変化が小さく斜面 (2) が大きいこと, 谷底はどの深さでもほとんど日変化がないことがわ かった。

（4）天空率は 5 月下旬から 11 月末までの間どの地 点もほぼ同じで, 6 月下旬を最低 (7\% 前後)として徐及 にあがっていくが，抢抒む称 $10 \%$ 前後で推移する。12 月に入り雪が降ると一気に落葉が進み，35\%まで上昇 
した。一方林内の照度は 10 月に入ると上昇傾向を示 し, 落葉の前後で大幅なギャップは見られない。なお, 地表の照度に対して地上 $1 \mathrm{~m}$ の照度は常に約 2 倍を
示した。このような光環境と地温との関係についての 解析を今後試みていきたい。

\section{上海における夏季ヒートアイランドと海風の影響}

白迎㺵 (東北公益文科大) - 三上 岳彦 (首都大)

\section{1.はじめに}

本研究は, 日本で蓄積された研究成果を有効利用 し，途上国の実情に鑑み，観測およびシステム保守の コストを抑えながら，中国・上海に扔いて高密度簡易 自動観測システムを初めて構築し, 長期間にわたって 気象観測を実施して得られたデー夕に基づいて, 海風 の影響に着目して夏季に扔ける上海のヒートアイラン ド（以下 UHI と略記）の特徵を解明することを目的と している。

\section{2. 観測データ}

本研究では, 2005 年 4 月から上海市をカバーする 39 箇所で気温と湿度の自動観測が実施されている。公園 緑地・公用緑地で百葉箱（箱内の小型自動記録式温度・ 湿度ロガー）が設置され，直射日光を受けずに自然通 風状態で測定を行うことができた。10 分間隔で記録し たデー夕を約 50 日ごとに回収している。今回は 2005 年 9 月までの 18 䇢所のデー夕を使用した。その他に, 上海気象局中心気象台の降雨量，風速・風向デー夕を 用いた。

3. 夏季ヒートアイランドに及ぼす海風の影響

上海は北緯 $31^{\circ} 14^{\prime}$ ，東経 $121^{\circ} 29^{\prime}$ の長江（揚子江）下 流デルタ地帯に位置している。東は東海に面し, 南は 杭州湾, 西は江蘇省, 浙江省と接し, 北は長江の河口 である(図)。本研究では, 海風は海よりの風(北東〜東 〜南東〜南) を定義した。

(1) 高温地域の分布

2005 年においては, 最高気温 $38^{\circ} \mathrm{C}$ を超える日数が

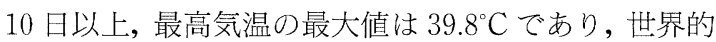
に見ても異常な高温化が顕著となっていることが確認 された。

観測によると, 夏季の日中においては, 海風（北東 〜東〜南東〜南) の進入のため，市の東部で高温域が 緩和され，市の南西部が高温域になった。しかし，都 心, 市の東部とも海よりの風の影響を受けているが, 海 風の風速が $5.0 \mathrm{~m} / \mathrm{s}$ 以上になっても，南西部での気温 低下は認められず，午後 3 時頃明瞭な UHI が見られ た(温度差 $3.5-4.0^{\circ} \mathrm{C}$ )。

一方，陸よりの風（南西〜西〜西北）が吹く夜にお
いては，市の東部を中心とする発達したUHI が見ら れた。

（2）昇温の頭打ちとヒートアイランド強度の日変 化

気温の日変化をみると，市の東部では，海よりの風 が吹くと, 午前中の昇温が頭打ちになり, 海風により 昇温しない状態のまま日中がすぎるという傾向があっ た。また，海風による冷却効果によって，午後は気温 の上昇は見られなかった。一方，市の南西部では，海 よりの風（特に北東風）が吹くと, 午後 3 時以後, 気 温の上昇が頭打ちになり，北東風の影響で都心部の高 温域が移動されたことが考えられる。

また，都心と東南海岸の気温差をUHI 強度とする。 海よりの風が吹くと，UHI 強度のピーク值は，12-13 時に現われた。晴天無風の日においては, UHI 強度は 日没後急速に増加し，その後は同じような状態が日の 出頃まで続くことが明らかになった。

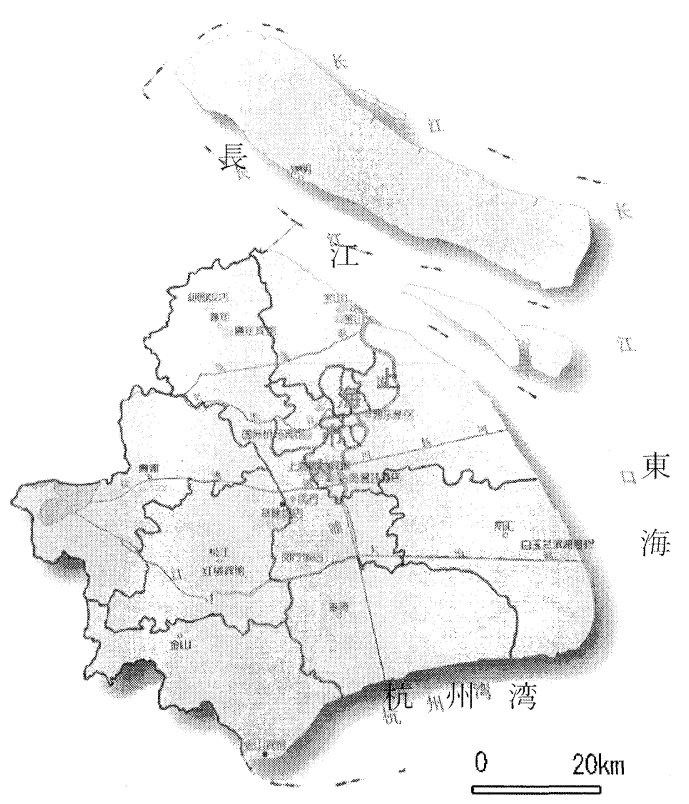

図上海周辺の地理的位置 


\section{日本における近年の黄砂観測日数変動と关の総観場}

本研究では黄砂が最も多く観測される4月を対象 に，東アジアの気圧配置と黄砂のふるさとである中国 大陸乾燥地域におけるダストストーム発生頻度との関 係について明らかにすることを目的とした。さらに舞 い上げられた砂を輸送する上空風の経路と日本におけ る黄砂観測日数の地域性についても考察を試みた。

日本全国 123 地点の気象台・測候所に扔ける黄砂観 測日のデータをもとに黄砂が観測された日数とその地 域性にもとづき 1996 年から 2004 年の各年を 3 つの ケースに分類した。ただし，全国で例年をはるかに上 回る観測日数を記録した 2002 年は特異年として別に 扱った。このケース分類にしたがって東アジアの月平 均海面気圧分布および上空 $700 \mathrm{hPa}$ 面の風を比較し た。その結果，黄砂が全国的に多く観測されたケース や2002 年の事例（図）では，4月の総観場において北 太平洋から中国大陸へのびる $1,010 \mathrm{hPa}$ 以下の低圧部 が他のケースよりも西の東経 125 度付近にあり, 中国 内モンゴル東部や東北平原を中心にダストストームの 発生を引き起こすとされる寒気の流入しやすい気象条 件であったことがわかった。また，このケースにおけ る上空風はモンゴル高原や東北平原といった比較的高 緯度に位置するダストストーム発生地域から北日本を 結ぶ経路をとることも示された。黄砂が西日本を中心 に観測されるケースや全国的に黄砂の少ないケースで は，低圧部の中心が 4 月にはまだ中国大陸の東海上に あり，寒気をもたらすと考光られる低気圧活動は先の ケースほど活発ではなかったことが示された。これら のケースでは日本までまとまった黄砂が到達した事例 が多くても1ヶ月で1回のイベントであり，穴の頻度 の低さから月平均の上空風と黄砂観測地点の地域性と の対応はあまりよくなかった。

\section{加 藤 洋 祐 (東北大。院)}

日本における 2000 年から 2002 年の過去に例を見な い黄砂観測日数のピークは，西日本において観測日数 が増加したことはもちろん，例年ほとんど観測されな い北日本においても急増し, 全国的に大規模な増加と なったことが特徵である。それは平年に比べ北太平洋 からのびる低圧部が西に偏って位置していたことによ り，内モンゴル東部や東北平原でダストストームを引 き起こしやすい気象条件であったことと，上空風がこ れらの地域で舞い上がったダストを西日本だけではな く北日本にも輸送しやすい経路をとっていたことが原 因であったと考えられる。

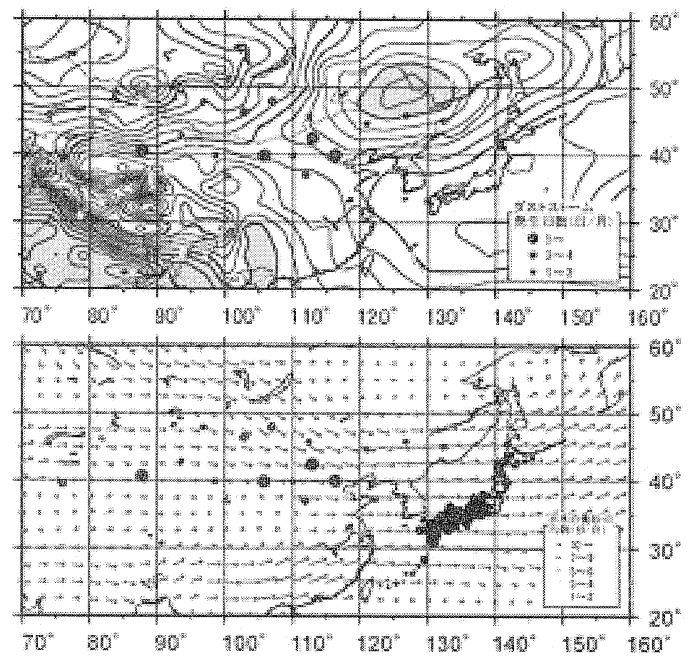

図 2002 年 4 月の平均海面気圧分布と中国大陸にお けるダストストーム発生日数（色をつけた領域は $1,010 \mathrm{hPa}$ 以下の低圧部を示す）（上）と上空 700 $\mathrm{hPa}$ 面上の風ベクトル (下)

\section{寒冷前線通過時に東北地方の地形が前線に与える影響}

\section{佐 藤 賢一（東北大。院）}

山岳をはじめとする地形が気像や気候に影響を与え ていることは多くの先行研究から明らかとなってい る。先行研究では寒冷前線が中部山岳地域を通過する 際，地形の影響を受けて，前線が変形したり，前線の 後面に流れ込む寒気が地形の影響を受けることで，風 系が複雑な変化をしたりすることが明らかとなってい
る。

一方，東北地方も奥羽山脈が南北に走行し，地形的 起伏に富んでいる地方であるが，寒冷前線通過時の地 形の影響についてはあまり議論されていない。よって, 本研究ではアメダスデータを用いて，東北地方を寒冷 前線が通過したときに東北地方の地形が前線に与える 
影響や風系の変化について調べた。

まず，「数時間（2～5 時間）南寄りの風が吹いた後， 西または北西寄りの風に変化し，それが 5 時間以上持 続した場合，風向が西または北西に変わった時刻」と いう定義に基づき，各地点における寒冷前線の通過時 刻を求め, 寒冷前線の地形による変形を調査したとこ ろ, 中部山岳地域と同様に前線の変形や進行の遅れが 見られた。特に，八幡平や岩手山が存在する秋田県と 岩手県の県境付近, 越後山脈が存在する新潟県と福島 県の県境において進行が遅れやすく，逆に平野部では 進行が早くなる傾向にあることがわかった。

次に各地点の風向。風速加寒冷前線後面に流れ込 む寒気の流入経路を調査したところ，(1) 飯豊連峰と 越後山脈の間の阿賀野川沿いを通過する経路，(2)山 形県と宮城県をつなぐ板谷峠や鳴子を通過する経路, (3) 秋田県と岩手県南部をつなぐ奥羽山脈の中でも比 較的低い山を通過する経路などが考えられるほか，周 辺の地形の影響により，その地点特有の風向を示す地 点もいくつか発見できた。特に青森県の碇ヶ関，秋田 県の阿仁合，岩手県の荒屋，沢内，福島県の桧枝岐な どでは周辺で西から北西の風が卓越しているのに対 し，南風が卓越しており，これは長野県の伊那谷でよ く観測される「地峡風」と同様の現象であると考えら れる。これまで地峡風は北西風が発達する冬季季節風 時に現れやすいということであったが，寒冷前線通過 後においても地峡風が現れるということがわかった。

次にどのスケールの地形がこれらの寒気の流入に影 響を与えているかを「気候緩和評価モデル ver2.0」を

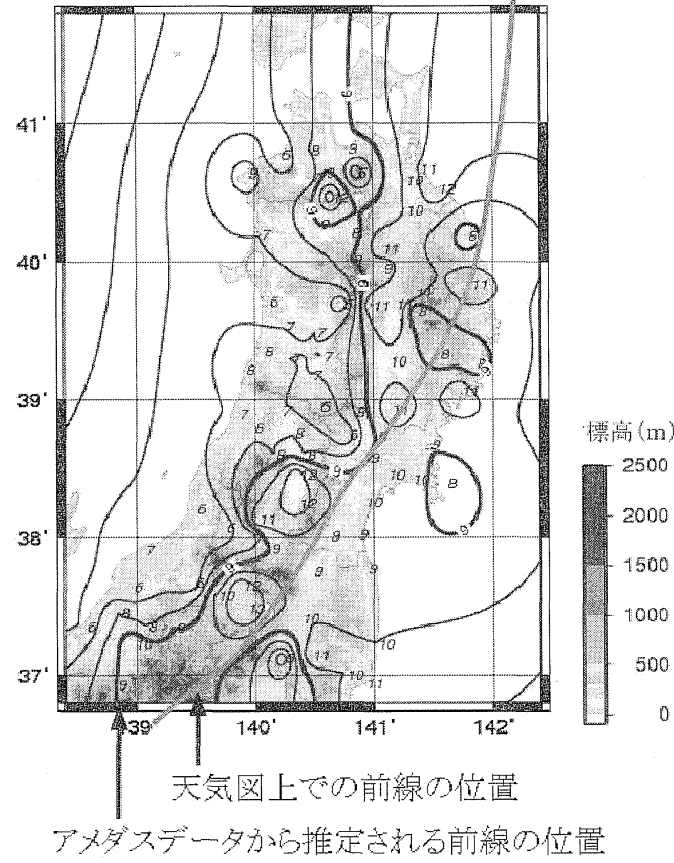

図 寒冷前線の変形の様子

用いてのシミュレーションによって調査した。 $3 \mathrm{~km}$ メッシュでシミュレーションを行なったところ，岩手 県の北上盆地では谷に進入する南風が検出できたが, それ以外の地域では南風は検出できなかったため，3 $\mathrm{km}$ メッシュ以下のスケールの地形が影響していると 考えられる。

\title{
仙台市におけるソメイヨシノの開花日と気温の関係
}

\author{
境田 清隆（東北大）・渡辺 一弘（NECソフトウエア）
}

Kiyotaka SAKAIDA and Kazuhiro WATANABE : The Prunus yedoensis Flowering Date in Sendai and its Relation to the Temperature

\section{1. 目的}

ソメイヨシノの開花などの植物季節は，気候学の立 場からは，それが気候のどの部分と関係するのか（何 の指標となるのか）という問題があり，指標性が明ら かになればそれを用いてミクロな気候を知る，あるい は歴史時代の気候復元などへの展開が可能となる。本 研究は指標性を意識しながら，まずはソメイヨシノの 開花日の空間分布から仙台市内外の気温の地域性を明 らかにすることを目的とした。
2. データ

ソメイヨシノの開花日データは，まず自身による目 視調查によって得た。3月の予備調査によってソメイ ヨシノの対象木を選定し，56 地点について 4 月の 10 日から毎日バイクによる目視調查を実施した。また市 内外の小中学校 111 校に開花日調査を依頼した。気象 打による開花の定義は「1 本の木に 5～6 輪の開花が認 められたとき」であり，今回はこれをそのまま採用し た。各地点で対象木が複数本あるときは，その半数以 上で開花が確認できた日を開花日とした。小中学校へ 
の依頼もそれらの定義を明示した。回答が寄せられた 小中学校は 48 校で, 自身の調査と合わせ，104 地点を 対象とした。

気温デー夕は, 約 20 校の小学校の百葉箱に既に設置 済みの温度計から得た。開花を調查した地点の気温は これらの小学校のデータを内挿して求めたが，小学校 の観測網の外側に位置する地点については, 気象庁の メッシュ気候值を参照して求めた。

3. 開花日と春季気温の分布

開花日は都心とその南側で早く，東部沿岸部と西部 丘陵部で遅く, その差は最大 12 日に及んだ。また都心 に近くても河川付近など海風の吹走しやすい地点や丘 陵の脚部では遅くなった。これらの傾向は仙台平野に おける春季の気温傾向と一致し, 開花日と 3 月の月平 均気温は有意な負の相関関係を示す。顕著な 4 つの外 れ值を除外すると -0.77 と明瞭な負の相関を示した。

4. 開花日と春季気温の経年変化

仙台管区気象台に扔ける 1961 年から 2004 年までの
ソメイヨシノの開花日 $(\mathrm{Y})$ と 3 月気温 $(\mathrm{X})$ は有意な 負の相関関係 $(\mathrm{r}=-0.85)$ を示し, 回帰式は $\mathrm{Y}=-$ $3.89 \mathrm{X}+29.9$ となった。これは熊谷の場合（松本ほか, 2003）に近似する。

5. 温度変換日数法を用いた開花日の予測 温度変換日数法とは日平均気温が $15^{\circ} \mathrm{C}$ の日に 1 日 で成長する量を 1 として, 相対的な成長量を積算し,そ れがある值に達したら開花するという考元方で開花日 を予測する方法である。仙台の経年データに当てはめ ると, 標準誤差は 1.25 日となり, 高い精度で開花日が 予測できる。仙台市内 48 地点の 2005 年の空間データ に当てはめると，標準誤差は一2.69 日と経年デー夕に 比べ少し大きくなった。しかし，その標準偏差は 1.95 と比較的小さいことから，3 月下旬の気温が平年より 低かったため全体的に予想より遅れたものの，ソメイ ヨシノの個体差は小さく,ソメイヨシノの開花日はそ の地域の気候を表すよい指標であるといえよう。

\section{静岡平野の海陸風を題材とした高等学校における課題研究の指導方法}

\section{吉 川 契 子（静岡県立静岡中央高）}

高校理科の教科書に海陸風の研究方法が取り上げら れているが，生徒にとって必ずしもわかりやすい手引 きとはなっていない。筆者は, 静岡平野の海陸風を題 材とした自然科学系部活動の課題研究の適切な指導方 法を明らかにすることを目的として，地学部生徒を指 導して 1999 年より,静岡平野の海陸風の課題研究を実 施している。文献調查により, 研究方法を調べ, 高校 生でも取り入れられる内容を検討した。研究成果は, 学 校内外に公表し，コンクール入賞も果たしている。

研究開始当初，海陸風を実測により調べたいと考え て風向風速を実測した。しかし，高校にある機械では， 弱い海陸風を連続して実測することが誠に困難である とわかった。そこで, 静岡県が大気污染監視を目的と して設置している観測点の風向風速データを提供して いただき，解析した。

1990 年から 1999 年までの高気圧などに覆われた晴 天日を抽出し，対象日について天気図を調べ(「気象年 鑑」), 台風や温帯低気圧が接近している日や冬型の気 圧配置の日など，一般風が強い日を排除して 158 日を 選び, 日の出日の入り時刻別に $2 \sim 4$ 月, $5 \sim 7$ 月, 8 10 月，11〜 月の 4 時期に分けた。次に，静岡平野の 12 の大気污染観測点の風向風速データから, 先に選び出 した日について四時期別・各時刻ごとの，最多風向・
平均風速を求め，風の流線図を描き傾向を調べた。そ の結果，以下のことが明らかになった。

(1) 静岡平野の海陸風は, 年間を通じて観測され, 海 陸風の入れ替わる「凬」は日の出日の入り時刻に応じ て変化し, 海風は日の出後 $2 \sim 3$ 時間後, 陸風は約 1 時 間後に吹き始め，典型的な海陸風の入れ替わり時刻の 傾向を示す。

(2) 風向は, 小丘陵や山地, 河川の谷などの地形に 影響される。

(3) 中心市街地で風速が弱くなり，丳の時刻が遅く なる傾向が見られ，ヒートアイランド現象やビルの影 響であると考えられる。

(4) 静岡平野の海陸風は, 中部山岳地帯に形成され る熱的低気圧の影響を受けることがある。

(5) 以上の得られた研究成果は静岡市内や静岡県内 の発表会や展示会で発表し，生徒の科学論文を静岡県 内のコンクール等に応募し，受賞させている。

(6) 同じ対象日について二酸化硫黄濃度デー夕の提 供を受け，海陸風が二酸化硫黄を運搬していることを 明らかにした。

(7). 今後ヒートアイランド現象と海陸風の関わりに ついて調査させていく予定である。 


\title{
西南日本における屋敷囲いとしての石垣の分布と様式について
}

\author{
漆 原 和 子（法政大）
}

Kazuko URUSHIBARA-YOSHINO: Distribution and the Styles of Stone Walls for Wind-breaks Surrounding Houses in Southwest Japan

本研究は屋敷囲いとしての石垣の分布と, 石積みの 様式の違いから，西南日本の文化圈を区分しょうとす るものである。

沖縄本島，喜界島，奄美大島などには，主に防風の ため築かれ，今も使用している屋敷囲いとしてのサン ゴ石灰岩を用いた石垣がある。1950 年代までは，わら 屋根の母屋を守るため，海岸に近いほど高い石垣を築 いてきた。その後トタン屋根や瓦屋根にかえても, 石 垣と生垣の屋敷囲いで防風している。しかし，石垣は 各戸の経済状態や，家の格の表現としての意味も有し ていて, 強風のところほど，風を弱めるため高い石垣 にする，という単純な分布にはなっていない集落があ る。喜界島の石垣は，琉球様式と，本州様式の両方の 石積みの方法がとられている。すなわち, 琉球様式の 石積みは野石を用いて，隅角を曲面でとり，そりは持 たない。このほかに, 石敢當が $\mathrm{T}$ 字路に埋め込まれて いる。門の内側にはヒンプンがある。一方本州様式は 隅角に特色があり，算木積みで，シャープな稜線を持 ち, そりがある。また, 喜界島の屋敷の入口は, 薩摩 藩の武家屋敷が持つ障子垣と同じ形式をふまえている 例が多い。従って，本州様式の影響も受けていること がわかった。九州南部知覧や, 出水には琉球様式の影 響が見られる。すなわち，ヒンプンを石塀ばかりでな く生垣で作る。また, T字路には石敢當が埋められて いる。一方太平洋岸の室戸では, 台風の強風をやわら
げるための石垣が分布している。これは本州様式であ ることがわかった。背後に $200 \mathrm{~m}$ を越える海岸段丘 (5e 面)の段丘崖をひかえる。その前面の, 幅の狭い沖 積平野に集落が密集する。これらの集落には 2 つ石 垣の形が見られた。太平洋に面する村では海岸までの 距離が $200 \mathrm{~m}$ 末満のとき, 崖側にぶつかる潮風の戻り 風がある。これを避けるため, 崖側のほうが海側のほ うより石垣が高い。しかし，室戸岬の東岸の幅 400 〜 $500 \mathrm{~m}$ に及ぶ平野の集落では, 海側からの潮風は, 崖 を吹き上がる。従って高い石垣は海側にのみ見られる。 室戸に分布する石垣は，隅角は算木積みで，そりを持 つ場合もあり，本州様式であった。

対馬では，冬の季節風を防ぐために野石を用いた石 垣が分布する。石積みの様式は，済州島で見る様式(琉 球様式と似る）と同じで，隅角に曲線を持つ石垣であ る。同時に，本州様式の算木積み（さんぎずみ）も共 存する。かつてはわら屋根であったため, 石垣を高く 築くことで防風効果を高める必要があった。屋根の強 度を高めるため，わら屋根から石屋根に変えた板倉が 現在も残っている地域がある。さらにより東側にある 壱岐島には，済州島の石垣の様式は全く見られず，本 州様式のみであった。

以上のような地域的な石積みの様式の違いから，西 南日本では石積みの文化圈が 2 区分されると考えた。

\section{横手盆地・北上低地帯の活断層と完新世の活動時期}

\section{水 本 匡 起 (東北大・研)}

Tadaki MIZUMOTO: Holocene Faulting Events and their Relationship on the Two Fault Zones at the Both Side of the Ou Backbone Range, Northeast Japan

東北地方は，活動的な島弧のひとつであり，太平洋 プレートの沈み込みによって東西方向の圧縮を受けて いる。そして，プレートの沈み込み方向と平行に，南 北に連なる山地や盆地列が認められる。近年は, 構造 探查によって地下の地質断面と活構造のイメージング が行われ，地表と地下の活断層の形状を明らかにしよ
うとする研究も行われている(佐藤・平田，1998）。そ れによると，奥羽猆梁山脈東縁の北上低地西縁断層帯 は，第三紀に形成された正断層のインバージョンテク トニクス（中村，1992；岡村ほか，1994）と考えられ ている。一方，西縁の横手盆地東緑断層帯は，東西圧 縮場のもとで生じた新しい逆断層である（佐藤ほか, 
1999 ; Sato et al, 2002 など)。そして，両断層に挟ま れた脊梁山脈北部は，東西幅 30-40 km の山地が隆起 する典型的な pop-up 構造であることが示されている (佐藤・平田，1998；平田㴽か，1999）。

奥羽资梁山脈両縁の活断層は，過去数万年間の変位 量や平均変位速度より，数千年間隔で繰り返し活動し ていると予想される。したがって，活断層の活動性を 高精度で明らかにするためには，複数回の活動を分離 できる変位基準が必要である。本研究では，形成時代 の異なる複数の完新世地形面を変位基準として用い, 過去 1 万年間における断層活動を示す。そして, 既存 の知見（トレンチ調査等で得られている活動時期の データ）を加えて，脊梁山脈両緑に位置する活断層の 完新世活動時期を比較することを目的とする。

横手盆地の活断層は, 最新活動が 1896 年の陸羽地 震，一つ前の活動はトレンチ調查等により約 3,500 年 前前後とされている(千屋断層研究グループ，1986 な ぞ)。完新世段丘面の変位を調査した結果, 陸羽地震で 活動した区間 (断層带北部) では，3,500 年前の活動が 段丘面上に変位地形として確認できることが明らかと
なった。さらには, 約 6,000 年前に形成されたと推定さ れる地形面にも変位が累積していることから，完新世 に少なくとも 3 回の断層活動が示された。

一方，北上低地带の活断層は，その北部において， 3,300 年前以降 (後藤ほか, 2003), 4,500 年前前後 (岩 手県，1996），6,000 1 万数千年前（渡辺ほか，1994） の活動が指摘されている。完新世後半に形成されたと 推定される地形面上には, 崖高 $1 \mathrm{~m}$ 前後の低断層崖が 認められる。また，完新世前半に形成したと考元られ る段丘面には，約 $3 \mathrm{~m}$ 前後の比高を有する低断層崖が みられる。したがって，トレンチ調査で示された完新 世の断層活動は，地形面の変位からも確かめられた。

これら脊梁山脈両縁の完新世断層活動時期を比較す ると，両断層带は交互に活動を繰り返している可能性 が高いことが示される。今後は，山地を挟んで交互に 活動するタイプや，同じような時期に活動するタイプ などに断層帯を区分し，それぞれの断層帯の分布（位 置）と活動の関連性を検討することが必要であると考 えられる。

\title{
踏査による福岡県西方沖地震の被害実態図作成
}

\author{
黒木 貴一 (福岡教育大) ・磯望 (西南学院大)・ \\ 後藤 健介（長崎大）。高本隆
}

Takahito KUROKI, Nozomi ISO, Kensuke GOTO and Takashi TAKAMOTO : Distribution Map of Damages Estimated by Field Survey on the 2005 West off Fukuoka Earthquake

福岡県西方沖地震 (2005 年 3 月 20 日, M 7.0) では, 福岡市およびその周辺地域の港湾施設や家屋を中心に 大きな被害が生じた。この地震による福岡市市街地の 構造物の被害に関し，延 5 日間の踏查を実施した。そ の結果から地震の被害実態の分布図を作成し評価し た。

福岡市博多区と中央区を中心に道路沿いの地物（木 造建物や鉄筋建物などの構造物，壁，床・地面）を観 察し，その亀裂に関しダム等の基礎岩盤にある割れ目 の区分を参考に被害程度を記録した。木造建物は $1 \mathrm{~F}$ と $2 \mathrm{~F}$ 以上に，鉄筋建物は $2 \mathrm{~F}$ 以下と $3 \mathrm{~F}$ 以上に分 しそそれぞれ龟裂の規模で 1 から 5 に階級区分した。花 壇や駐車場などの四角囲みの壁に関しては，亀裂の開 口量 $(\mathrm{mm})$ を計測し，家屋境界のブロック塀に関して は脱落の程度で 1 から 4 に階級区分した。床・地面に 関しては，床夕イル破損を 1 から 3 に，柱・壁と床・ 道路境の破壊を 1 加 3 に階級区分し, 床・道路に生 じた鲁裂は開口量（mm）を計測した。

被害実態の分布図を作成するために，アンケート回 答からの震度推定方法の考え方を参考にした。調査中 の記録や被害程度の分布状況を考慮しつつ，異なる地 物の被害の階級区分や開口量に関し，近接する場所で の共存状態を確認した。各地物の被害程度の階級区分 等を共通階級区分 1 から 7 に対応付けた。次に各観察 地点の共通階級区分の分布情報を元に，ArcView8.3 $の$ Spatial Analyst $の$ Inverse Distance Weighted $の$ 方法でメッシュサイズ $20 \mathrm{~m}$ の補間をし，被害実態の 分布図を作成した。

被害実態の分布図と別途作成した基盤深度分布図お よび地形区分図とを比較したところ以下のことが分 かった。1）警固断層は顕著に，那の津断層は不明瞭な がら，被害実態の分布の境界線に一致し，その断層線 のすぐ東側で被害程度が大きい。2）基盤の深い場所で は被害程度が大きく，逆に基盤の浅い場所では被害程 


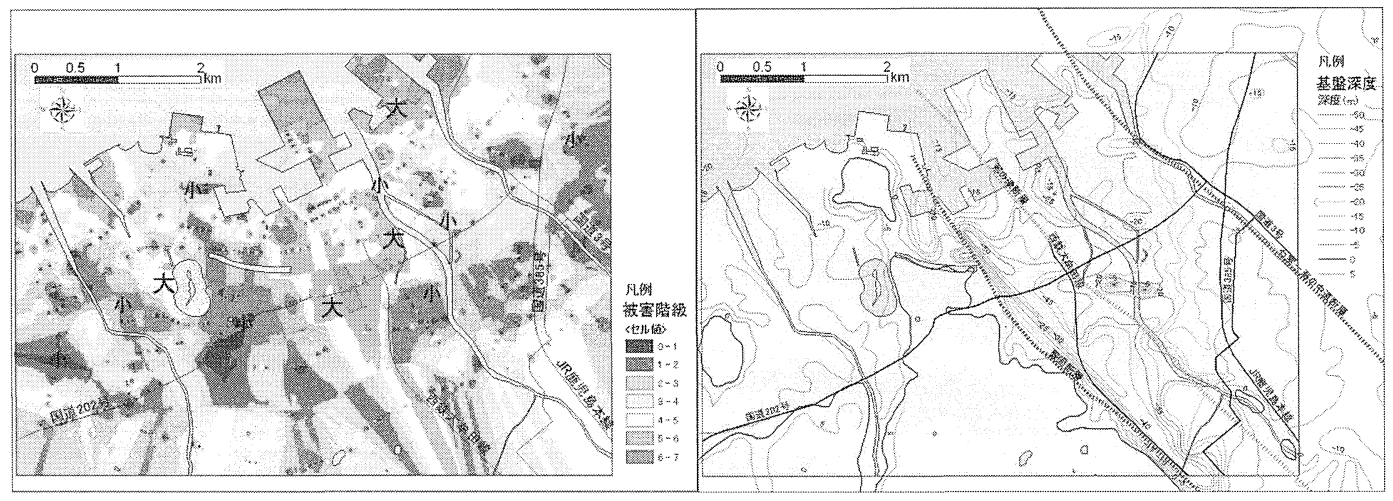

図 推定した被害実態の分布（左）および基盤深度の分布（右）

度が小さい。3）自然堤防と砂丘では被害程度が小さ い。4）沖積低地，沖積低地と丘陵地の境界では被害程 度が大きい。これより，踏査による様々な構造物にあ
る㫣裂調查の結果を，定めた基準で階級区分された地 震被害実態として整理し，GIS でその分布を推定でき ることが分かった。

\section{九州における河川の水質と地理的要素との関連}

\section{高見 昌志 (福岡教育大・院) ・黒木 貴一。石黒 正紀 (福岡教育大)}

Masashi TAKAMI, Takahito KUROKI and Masanori ISHIGURO: The Relationships between Various Water-qualities of River and Geographical Elements in Kyushu Island

生物多様性や地球温暖化などの環境問題への意識向 上とともに私たちの生活には欠かせない飲料水や農業 用水などの水質に対して近年，大きな関心が寄せられ ている。環境科学分野では，実測を行い，水質を変化 させる環境要因の検討が多く行なわれてきた。また 小・中学校の理科教育では, その研究成果の教材化も 進んでいる。しかし，それらは小流域の狭い範囲に関 心が向き，河川の流域全体を対象とする研究や教育に は進んでいない。地理では，広い流域に対して水質と 土地利用分布や地質分布等の地理的要素との関係につ いて,重ね合わせによる検討が進められてきているが, まだ研究蓄積が少ない。また水質の上下流方向の，経 年的・季節的な時間・空間的な変化傾向を探ろうとす る試みはほとんど無い。

本研究は，九州の一級河川の流域を対象に，GIS を 用いて水質と地理的要素との関連を明らかにすること を目的とする。今回は 20 の一級河川を上下流方向で見 たときの, 水質調查項目 (EC, SS, T-N, T-P, pH, DO, $\mathrm{BOD}, \mathrm{COD}$ ) の変化（経年，季節）の特徵を明らかに する。また，事例として筑後川流域の水質変化の傾向 を明らかにする。
水質データ (1984 年，1994 年，2004 年) は国土交通 省の一級河川にある水質調查地点の観測值を，土地利 用データは国土数值情報 (1976 年, 1987 年, 1991 年, 1997 年)を，地質と地形の各デー夕は $1 / 50,000$ 土地分 類基本調查（地形分類図）を用意した。水質は調査項 目ごとに 4 力年の平均を規準とする特化係数に換算し た。

各河川の水質を上下流方向で見た場合，a：下流ほ

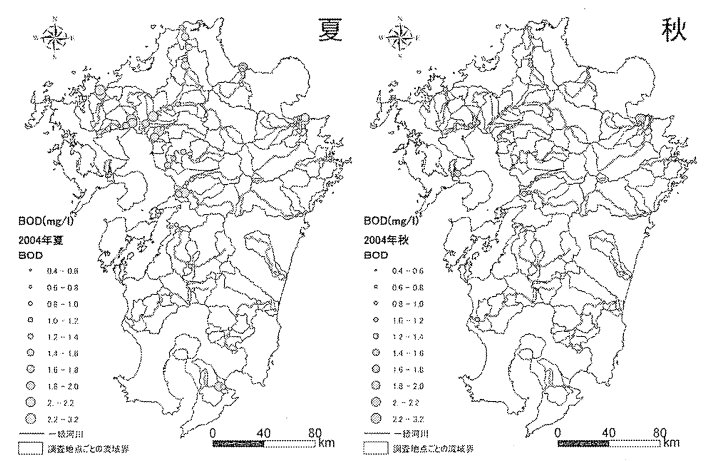

図九州島の一級河川における BOD 観測值 (2004 年 夏抢よび秋) 
ぞ值が上昇する， b：中流で值が上昇する， $\mathrm{c} ：$ 中流で 值が低下寸る, d : 上流のみ值が高い, e : 推移しない, $\mathrm{f}$ : 欠落データが多く傾向が不明, の 6 変化型に区分で きた。九州全河川の変化型の経年変化を調查項目ごと に見ると，1）近年ほど,水質の変動が上下流で見られ ない e タイプの割合が増えてくる，2）タイプ構成比 の季節変動が大きいものと小さいものがある，ことが わかった。筑後川流域で同様の検討を行ったところ, 1）項目と季節によって上下流に㧍ける值の変化の仕

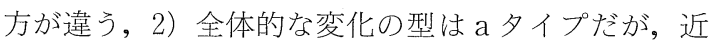

年では上流の值が増加し下流の值が減少することで b , c d d タイプが消滅し，eタイプに収束する傾向があ る，3）全体を見ると秋が最も穏やかである(図)，こ とがわかった。

今後は，1）水質変化の特徵が見られる流域を見出 し，2）その流域についてょり詳細な調查を実施し， 3）水質変化と地質, 地形, 土地利用の地理的要素がど のような関連をもつかをGIS で分析し，4）水質変化 の特徵を生み出す社会的要因を探りたい。

\title{
宮城県北西部鉛川の湧水と水質特性
}

\author{
清野 茂・小山 孝昭・牧滋・佐藤勤・ \\ 嵯峨 京時 (宮城県保健環境センター)・ \\ 大庭 和彦（宮城県栗原保健福祎事務所）。
}

藤巻 宏和（東北大）

Shigeru SEINO, Takaaki KOYAMA, Shigeru MAKI, Tsutomu SATO, Kyoji SAGA, Kazuhiko OHBA, and Hirokazu FUJIMAKI : Assessment of Springwaters in Namari River Water System, Northwestern Part of Miyagi Prefecture

鉛川最下流では河川中の $\mathrm{Pb}$ などの重金属が環境基 準を超過している。超過原因は，「河床・河岸に高濃度 鉛を含有する湧水など地質構造由来の自然污濁」(宮城 県）とされてきた。現在では，鉛川上流に位置する細 倉鉱山 (現細倉金属) の排水中には $\mathrm{Pb}$ など重金属は未 検出である。そこで，超過原因の「地質構造由来の自 然污濁」を精查する必要となり, 平成 14 年度から 3 年 間湧水調查を実施し，重金属や一般水質測定，河床堆 積物の浸漬実験により涌出機構を検討した。さらに, 水 質のパターンダイアグラムや多変量解析手法により湧 水の水質特性を明らかにした。

\section{1. 鉛川の地形}

鉛川上流は渓谷，下流にしたがって開析した沖積地 (河道勾配約 $2 / 100$, 以下同様) となり，尾根が谷底に せまる渓谷(約 $1 / 100$ ) となって，さらに下ると谷口の 出口部に当たり，河岸段丘を形成し，調査区間で最も 急峻（約 3/100）。下流域は汇濫原となり(約 9/1000), 旧河道は蛇行していたものの河川改修工事により現在 は直線化された。この区間の河道勾配は最も緩い（約 $4 / 1000)$ 。

\section{2. 湧水の湧出機構}

湧水は 47 力所，その内 15 力所は側壁湧水。表流水 が出入りする河床堆積物すなわち「河床間隙水域 (Hyporheic Zones, 以下HZと略す)」(Stanford,
1988; Winter et al., 1998; Lamontagne et al., 2003) が存在し，重金属高濃度含有湧水は，HZ 中の水みちに 堆積する脈石と伏流水や浅い地下水が反応し，硫化鉱 物を $\mathrm{SO}_{4}$ に酸化し，重金属を溶出すると考元られた。

3. 湧水の多成分パターンダイアグラム

湧水は 4 分類された。 $\mathrm{A}$ 群: 各成分とも表流水とほ ぼ同濃度で $\mathrm{Pb}$ は低濃度であり, 上流で表流水が伏流 し再涌出した $\mathrm{HZ}$ 水。 $\mathrm{B}$ 群: $\mathrm{A}$ 群よりも $\mathrm{Pb} \cdot \mathrm{Cd}$ が高 濃度で, 典型的な「高濃度湧水」。C 群: 各成分とも低 濃度で，山地渓流の基底流出水。 $\mathrm{D}$ 群: $\mathrm{F} \cdot \mathrm{SO}_{4} \cdot \mathrm{Mg}$ ・ $\mathrm{Cd} \cdot \mathrm{Pb}$ あるいは $\mathrm{Cd}$ または $\mathrm{Mg}$ が高濃度。鉛川中・下 流注打る重金属負荷の増大要因は，B 群の湧水であ ると考えられる。

\section{4. 多変量解析による湧水の水質解析}

46 湧水の 10 成分 $(\mathrm{pH} \cdot \mathrm{Pb} \cdot \mathrm{Cd} \cdot \mathrm{Zn} \cdot \mathrm{F} \cdot \mathrm{Mg} \cdot \mathrm{Ca}$ ・ $\mathrm{SO}_{4} \cdot \mathrm{SiO}_{2} \cdot \mathrm{HCO}_{3}$ ) について主成分分析を行った。鉛 川の湧水水質は第 1 主成分は $\mathrm{HZ}$ からの重金属・ $\mathrm{SiO}_{2}$ の溶出, 事業所系排水等の総合的な涌水水質への影響 指標，第 2 主成分は HZ からの溶出成分，第 3 主成分 は $\mathrm{Pb}$ を強く反映する湧水で説明できる。さらに,クラ スター分析による湧水の水質区分では 3 分類された。 (1) 事業所系排水由来の河川水が伏流し再湧出した湧 水 (HZ 水) で，前述の $\mathrm{A}$ 群 (以下同様) に当たり，(2) $\mathrm{HZ}$ 水, 堆積物中の脈石と伏流水や浅い地下水の反応 
由来の湧水及び山地斜面基底流出水の側壁涌水，前者 は B 群, 後者は C 群に当たる。(3) は露頭地带の涌水, $\mathrm{D}$ 群に当たると解釉できた。

\section{5. 河床堆積物の浸漬実験}

各成分とも 1 日目に溶出した。各成分の溶出状況は 河川水と比べると異なっていた。 $\mathrm{Pb} \cdot \mathrm{Zn}$ は 5 日目で河 川水より低值, Cd は 5 日目でも河川水より高值であっ
た。 $\mathrm{K} \cdot \mathrm{Cl} \cdot \mathrm{NO}_{3}$ は 2 日目から河川水より低值で, $\mathrm{Ca}$ ・ $\mathrm{SO}_{4} \cdot \mathrm{Mg}$ は 1 日目から低值。 $\mathrm{F} \cdot \mathrm{SiO}_{2}$ は河川水と同值 で, $\mathrm{Al}$ は河川水よりも高值であった。浸漬実験結果は, 脈石を混在する河床堆積物を出入する $(\mathrm{HZ})$ 水質は $\mathrm{Pb} \cdot \mathrm{Zn} \cdot \mathrm{Cd} \cdot \mathrm{Al}$ が高く，一方 $\mathrm{Ca} ・ \mathrm{Mg} ・ \mathrm{SO}_{4}$ などの 陽・陰イオンが低いことを示唆している。

\section{岩手山麓地帯の不圧地下水における硝酸性窒素濃度の分布と季節変化}

\section{豊島 正幸（岩手県立大）。伊藤＼cjkstart駿（JA 岩手県信連）}

近年, 地下水の硝酸塩污染が深刻化している。水質 污濁防止法に基づく 2002 年度地下水質測定結果によ れば，全国の調査井戸の $6 \%$ で環境基準値 $(10 \mathrm{mg} / \mathrm{L})$ を超過している。岩手県では同超過率は $30 \%$ 前後にも 達している（2002２004 年度）。

地下水の硝酸塩污染の問題漄対して，国は関係法令 を整備し, 窒素化学肥料の減肥など環境保全型農業の 推進や家畜排せつ物の適正処理などの対策をとってき た。しかしながら，同污染現象が主に農地への施肥な ぞ面源負荷であり，点源負荷の規制では解決できない こと, 硝酸性窒素濃度の年間変動幅（季節変化）が明 らかではないこと, さらに地下水流動の面的把握が困 難であることなど克服すべき課題は多い。

本研究では, 岩手山東麓地带の酪農・畑作地带を対 象に，第 1 に，地下水流動を推定するために，70 の涌 水地点の標高を基に地下水面図を作成する。第 2 に, 23 地点の湧水について，硝酸性窒素濃度を $3,6,7,9$ お び11月に計測し，季節変化を明らかにする。第 3 に， 硝酸性窒素濃度の季節変化の地域的差異（地点ごとの 季節変化特性）の原因について，地下水面図を基に考 察する。

結果は次の通りである。1）湧水の硝酸性窒素濃度 の季節変化は，全体的に低下 $(3 \rightarrow 6$ 月 $)$ 一上昇 $(6 \rightarrow$ 7 月)一低下 $(7 \rightarrow 11$ 月) を示した (図)。2）涌出量の 測定 (1 地点) 扔よび降水量データと照合した結果, こ
の季節変化には降雨が強く関与しており,まとまった 降雨が硝酸性窒素濃度を上昇させることが判明した。 3） 7 月から 11 月への硝酸性窒素濃度の低下過程を地 点ごとに詳細に検討した結果，9月にかけて速やかに 濃度低下した 5 地点のうち，4 地点が地下水面図の谷 部に位置することが見い出された。これらの地点では 地下水の流れが収束し流速も相対的に大きいため, 希 釈されやすいと考えられる。

以上より, 地下水の硝酸性窒素濃度の季節変化には, 地下水への負荷量を左右する降雨条件に加えて, 希釈 の程度を左右する地下水流の収束状況など地下水流動 パターンが大きな要因となることを指摘したい。

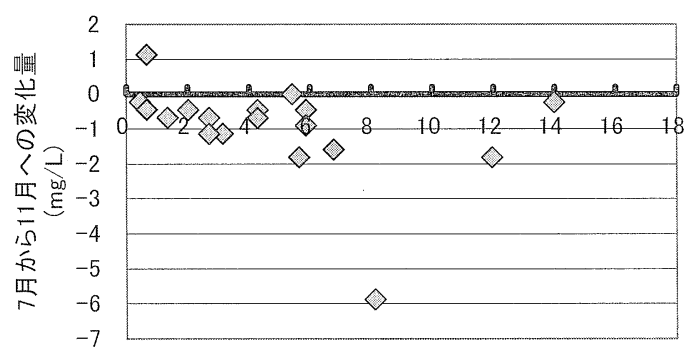

7月の硝酸性窒素濃度 $(\mathrm{mg} / \mathrm{L})$

図 湧水の硝酸性空素濃度の季節変化の例（7月から 11 月)

\section{沖縄島中北部，辺野古付近のリニアメント}

\section{木 村 和 雄 (沖縄高專)}

琉球弧のほ潘中央に位置する沖縄島は，島弧の延長 方向に並行して伸びる細長い島であり，行政的には仲 泊一石川地峡を境に，国頭（くにがみ）あるいは山原 (やんばる) と呼ばれる北部と，中頭 (なかがみ) およ び島尻から成る南部に大別されることが多い。この区
分は地質地形分類においても有効で，鮮新世以降の堆 積岩類のみが露出し, 最高地点の標高が $200 \mathrm{~m}$ にも満 たない低平な段丘・低地のみから成る南部に対して, 北 部は古第三紀以前の付加体を基盤とし標高 $500 \mathrm{~m}$ に 達する侵食山地が発達し，それを取り囲んで中期更新 
成以降に形成された丘陵・段丘が分布するなど，対照 的である。さらに本部半島を除く北部は，津波(つば) 一ギナン崎を結ぶ線を境にやや様相を異にする。島の 最北部は，早壮年期的な侵食山地が脊梁（分水嶺）を 成しつつ広く発達しており，段丘・低地は海岸沿いの 狭い範囲に限られる。これに対して，その南側では，山 地は孤立峰として存在し，陸地の大半は中～後期更新 世に形成された段丘とそれが開析された定高性丘陵て 占められる。この津波一ギナン崎と仲泊一石川地峡に 挟まれた地域を便宜上，沖縄島中北部と呼ぶことにす る。

中北部には多数の地質断層やリニアメントが存在 し，一部は地形界とも調和的であるが，その実態はほ とんど知られていない。そこで本発表では，中北部の 典型的な地形配置が見られる名護市辺野古付近におい て，段丘面の分布・変位とリニアメントとの関係にう いて報告する。リニアメントのうち，大浦湾南西海岸 から楚久（すっく）を経て名護岳方向へ延びるもの（楚 久断層)，辺野古美謝川に沿って世富慶（よふけ）に至 るもの (辺野古美謝川断層)，沖縄高専直下を $1 \mathrm{~km}$ 余 り WNW-ESE 方向に走るもの (辺野古断層)，久志岳 と豊原の中間付近でほぼ南北方向に $1 \mathrm{~km}$ 余り延びる もの（豊原西断層）の少なくとも 4 つは，活断層の疑 いが極めて濃い。

辺野古美謝川断層では，断層を挟んで段丘面の高度 差と南西方向への傾斜が，古く高位・内陸よりのもの ほど大きく，若く低位・海岸よりのものほど小さくな る傾向が認められる。つまり同断層は明らかに第四紀
後半を通じて累積的に活動している。また辺野古美謝 川断層は, 沖縄本島を NW-SE 方向に胴切し, 辺野古 崎南東の海底にも延びており，総延長は $10 \mathrm{~km}$ を超え る。変位速度は大きくない (B-C 級 ?) と推定される ものの，断層の規模は琉球弧の陸上活断層としては破 格に大きく，被害地震を引き起こす可能性も否定しが たい。また断層直上・直近には，高度な災害耐性を要 求される軍事施設が多数立地し，今後も重要性が増す ことが想定されている。それゆえに精細な古地震学的 調査に基づくりスクの見積もりが必要ではないだろう か?

楚久断層は，周辺の地形配置の類似性から，ほほ並 行する辺野古美謝川断層と同様に活動し，大浦湾の形 成に寄与してきたと考えられる。辺野古断層では，新 鮮な右横ずれ変位が認められるが,明瞭なずれは $1 \mathrm{~km}$ 程度で途切れ，累積的活動を示す痕跡も見つかってい ない。このことから，辺野古断層は起震断層ではなく 近接する断層（辺野古美謝川断層？）の活動に伴って 付随的に生じた可能性もある。豊原西断層は，局所的 に，段丘群を数メートル西落ち変位させているように 見えるが，全区間が米軍演習場内にあって踏査不能の ため，詳細は不明である。また，辺野古美謝川断層〜楚 久断層のような北東落ちの正断層と，その上盤側の南 西へ傾斜した段丘・丘陵背面とから成る小地塊は，北 方へも繰り返し出現する。今後，本報告と同様の調査 をより北方へ展開し，地形面の編年を確立することで， 沖縄島中北部の地殼変動像を明らかにしていきたい。

\section{沖縄県古宇利島および屋我地島から採取したビーチロックの ${ }^{14} \mathrm{C}$ 年代と安定同位体比}

\section{小元久仁夫（日本大）・紺野 善崇（日本大・院）}

Kunio OMOTO and Yoshitaka KONNO : Radiocarbon Ages and Isotope Fractionations of Beachrock Samples Collected from Kouri Island and Yagachi Island, Okinawa Prefecture, Japan

\section{1. 研究目的}

沖縄島中北部に位置する古宇利島抢よび屋我地島で 野外調査を行い，ビーチロック試料を採取する。試料 の放射性炭素 $\left({ }^{14} \mathrm{C}\right)$ 年代測定と安定同位体比 $\left(\delta^{13} \mathrm{C}\right)$ の 測定を行う。測定結果からビーチロックの形成年代, 海 水準変動や地殼変動，ビーチロックの形成に陸水（地 下水）が関与したかどうかについて検討する。

2. 研究方法

現地調查の際に，レーザーレベルによるビーチロッ
クの地形断面測量を行い，ビーチロック試料を採取す る。試料は, 日本大学年代測定室で $\beta$ カウント法によ る ${ }^{14} \mathrm{C}$ 年代測定を行う。また各試料の年代について同 位体補正を行うため，年代測定に使用した二酸化炭素 を用いて，Micromass 社製 IsoPrime による安定同位 体 $\left(\delta^{13} \mathrm{C}\right)$ の測定を行う。各試料について同位体補正 後の年代を IntCal 05（Marine：04）により暦年に較 正し，ビーチロックの年代とする。 


\section{3. 研究成果}

古宇利島北部および東部の 2 地点，屋我地島北部の 1 地点でビーチロックを確認し，地形断面測量を行っ た。ビーチロックに含まれていた化石サンゴ (2)，貝 化石（7）および石灰質砂岩（2）の合計 11 試料（小元 が 9 個，紺野が 2 個)を採取した。各試料について ${ }^{14} \mathrm{C}$ 年代測定と安定同位体比 $\left(\delta^{13} \mathrm{C}\right)$ の測定を行い, ${ }^{14} \mathrm{C}$ 年 代を補正してビーチロックの年代を決定した。本研究 の成果は，次のように要約される。

（1）ビーチロックは古宇利島では高潮位（一部離 水) から低潮位に，屋我地島では中潮位から低潮位に みられ，現在波浪により侵食されている。

（2）試料の安定同位体比は，3.5\% 0.4\% (平均 2.0 \%) の範囲にある。

（3）この結果にもとづけば，同位体補正年代は約 $470 \sim 420$ 年 (平均約 450 年) となる。

(4) 古宇利島東部のビーチロックは, 約 3,100
〜2,600 Cal BP，北部では 1,200 Cal BP 頃に形成され た。一方屋我地島のビーチロックは，約 1,600～1,400 Cal BPに形成された。

（5）海成段丘およびビーチロックの高度と年代か ら，古宇利島では MIS-5e 以降およそ $0.35 \mathrm{~m} / \mathrm{ka}$ の隆 起が継続している。一方屋我地島の海水準は，1,600 Cal BP (4,500y BP) 以降現在とほぼ同じである。

（6）約半数の試料の安定同位体比は,海洋生物の平 均の安定同位体比 $(0 \pm 2 \%$ ) の範囲外（特に貝化石は すべて $+2 \%$ 超）にある。

（7）石灰砂岩の安定同位体比は $0 \pm 2 \%$ の範囲にあ ることからビーチロックの膠結時に陸水の関与はな かったと思われる。

（8）ビーチロックの形成年代は,沖縄諸島のビーチ ロックが形成された年代 (Omoto, 2006; 小元，2006) と調和的である。

\section{岩手山麓春子谷地湿原と周辺における晚水期以降のテフラ層序と地形形成}

吉木 岳哉（岩手県立大）・吉田 明弘（東北大・院）

岩手火山の東南麓, 標高 $460 \mathrm{~m}$ に位置する春子谷地 湿原に扔いて, 径 $5 \mathrm{~cm}$ のシンウォールチューブサン プラーを用い, 湿原西半部の 5 地点から湿原堆積物を 採取した。基底深度が約 $580 \mathrm{~cm}$ と最も大きかった地 点のコアを分析した結果, 泥炭層下位に秋田駒柳沢テ フラ $(\mathrm{Ak}-\mathrm{Y})$ の二次堆積物, 深度 $396 \mathrm{~cm}$ 付近に秋田 駒堀切軽石, 深度 $195 \mathrm{~cm}$ 付近に十和田中掫テフラ $(\mathrm{To}-\mathrm{Cu})$, 深度 $60 \mathrm{~cm}$ 付近に十和田 $\mathrm{a}$ テフラ $(\mathrm{To}-\mathrm{a})$, 深度 $30 \mathrm{~cm}$ 付近に岩手山起源の刚屋スコリアが認め られた。また, ${ }^{14} \mathrm{C}$ 年代測定を 6 層準で行った結果, 湿 原堆積物の基底が 13,580-13,270 cal yr BP, 深度 485 $\mathrm{cm}$ (今回の発表では触れていない花粉分析研究におい て, ブナ属の増加, カバノキ属の減少が認められた層 準) で 10,520-10,240 cal yr BP，秋田駒堀切軽石直下 で 9,910-9,550 cal yr BP, 深度 $305 \mathrm{~cm}$ (ブナ属のピー ク，コナラ属の一時的な極小を示す層準）で 8,600-

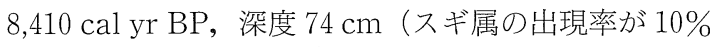
を超え始める層準）で 1,300-1,080 cal yr BP，刈屋ス コリア層下位で 490-290 cal yr BP の年代值が得られ た。これらの結果に基づいて湿原堆積物の堆積速度を 求めると，十和田中掫テフラ降下以前は $1 \mathrm{~m} / 1,000$ 年 程度と大きな堆積速度であるのに対し, それ以後は 0.2 $\mathrm{m} / 1,000$ 年程度に低下したことが示された。

湿原堆積物の堆積速度の変化は，湿原下流側を塞い
でいるように見える岩手山の火山麓扇状地の形成の影 響を反映している可能性がある。火山麓扇状地の扇頂 付近の露頭では十和田 a を挟む土石流性堆積物が厚 く堆積しているのが確認され, 最近でも活発に堆積を 行っていることが示された。しかし, 湿原の堆積速度 の変化と関係づけられる古い堆積物は確認できなかっ

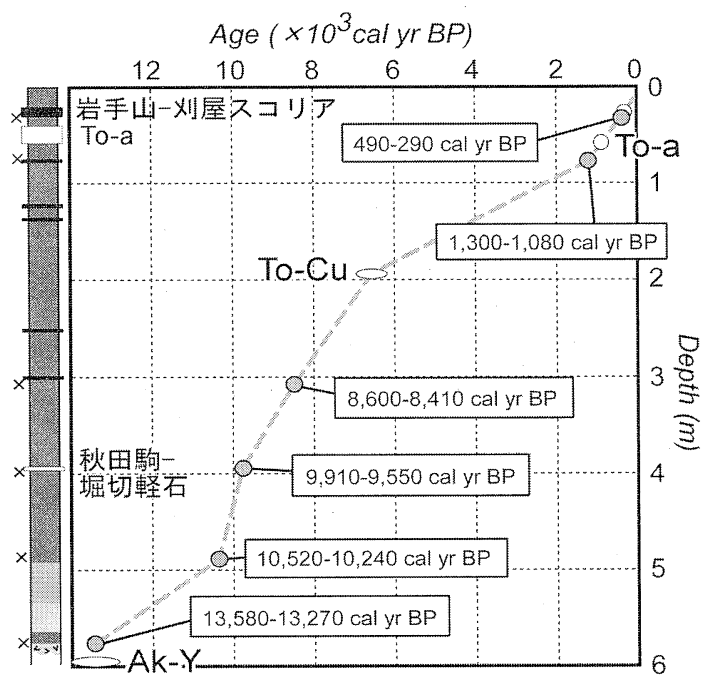

図 春子谷地湿原コア 4 採取地点における泥炭層の堆 積速度 
た。

また，近年，春子谷地湿原の下流部では，湿原域へ の森林の侵入と湿原の乾燥化が指摘されている。湿原 周辺は広く放牧地として利用されているため，草地か ら土砂が流出していることが原因とする意見もある。 しかし，湿原下流部の微地形，および，多くの地点で の堆積物深度と貫入值の分布加らは，湿原西部に流入
する小河川が小規模な扇状地を形成しており，その流 路が首を振ることによって湿原が時期的に多少広がっ たり狭くなったりしている可能性が示された。さまざ まな時間スケール・地形スケールで湿原の形成過程を 明らかにすることを通じて，現在の湿原の状態を客観 的に把握するとともに，自然資源としての春子谷地の 保全策を検討していくことを現在進めている。

\section{秋田県南部の珪質泥岩地すべり地における微地形発達と移動体内部構造}

\section{桧垣 大助（弘前大）・小原 褰子（(独）土木研究所）}

地すべり地の微地形は，基盤地質構造や地すべり発 生以降の移動体内部構造の変化を反映していると考え られる。ここでは, 秋田県南部の比較的硬質な新第三 紀層珪質泥岩分布地带にある狼沢地すべり・砥沢地す べりおよび既に報告した谷地地すべり（小原・桧垣， 2004）も含め，すべり面が形成されやすい弱層とすべ り面形状，地すべりによって受けた岩盤の破砕やその 後の風化など移動体内部構造の変化がどのように移動 体規模や微地形形成に関係するのか検討した。

1）弱層の存在状況：谷地地すべりでは，すべり面 が深さ $50 \mathrm{~m}$ におよび河川の下側を抜けて対岸にすべ り面が達している。いっぽう, 狼沢地すべりは，いく つかのブロックに分かれそれぞれ異なる凝灰岩層にす べり面が存在する。すべり面形状には深度方向の弱層 (ここでは細粒凝灰岩) の分布頻度が関係し，前者では それが深い位置にしか存在しないため川越えすべり面 となり，後者では多層に存在するため階段状すべり面 となった。その結果，前者では末端に隆起による分離 丘が，後者では階段状すべり面を移動地塊が乗り越え る位置に圧縮・引つ張りによる亀裂地形が作られてい る。また, 地すべりブロックの規模は後者が小さい。砥
沢地すべりでは，キャップロック構造をなす弱層の形 成されにくい安山岩層が破䂶珪質泥岩上に載るため, 深さ $150 \mathrm{~m}$ におよびかつ末端で川越えすべりとなる すべり面を形成，その結果，地すべりブロックの規模 が大きくなった。

2）移動体の破砕・風化：破砕程度として，各ボー リング孔のコアにおける岩構造の残存割合を調べた。 谷地地すべりと同様，狼沢地すべりでも，地すべり移 動量の大きい末端部のブロックで破砕が進んでいる。 また，コア中で岩構造の無い範囲は褐色風化範囲とほ ぼ一致している。上部が基盤岩の亀裂方向に対応した 方向性のある微地形からなるのに較べ，末端のブロッ クでは円凸の少ない微地形をなすが，これは，地す心゙ り移動による破砕・風化の進行により移動体構成岩は 土砂化し，表層の斜面変動が起きやすくなり凹凸の少 ない地形になったためと考元られる。また，砥沢地す ベりでは，キャップロック構造をなす破砕・風化を受 けにくい安山岩層が破砕珪質泥岩に載るため, 安山岩 の表面形状に対応した微起伏の少ない（吔や小丘な ど地すべり微地形の分布が粗い）地形となったと考え られる。

\section{西ジャワ, バンドゥン盆地南西縁の丘陵地を構成する地形類型}

田村 俊和 (立正大) -大久保 悟 (東京大) ・原科 幸爾 (岩手大) ・ 中川 雄助 (東京大・院) ・武内 和彦（東京大）。

Chay ASDAK (パジャジャラン大)

Toshikazu TAMURA, Satoru OKUBO, Koji HARASHIMA, Yusuke NAKAGAWA,

Kazuhiko TAKEUCHI and Chay ASDAK: Geomorphic Composition of the Hills

in the Southwestern Fringe of the Bandung Basin, West Java, and Erosion History Deduced from the Composition

バンドゥン盆地底は，南と北にある古期火山の間を 西流する河川が，主として北側の新期火山から供給さ
れた堆積物で遮られ, 扇状地堆積物と湖成堆積物の互 層で順次埋積されることにより, 発達してきた。盆地 
南縁に, 新第三系火山岩・火砕岩類加ら成る比高数十 〜 300m の丘陵地がある。盆地南西緑, ソレアン南方の 地域を対象に, 現地観察, 空中写真判読, 衛星画像解 析等に基づいて，いくつかのスケールでの地形類型を 設定し, 各類型の特性から, 侵食地形の発達過程につ いて論じる。

少なくとも中期更新世に遡ると思われるブブト火山 の北面は，海抜 $1,341 \mathrm{~m}$ の頂上を含む径 $2 \mathrm{~km}$ 弱の山 頂部（Ia）とそれをとり巻く山腹部（Ib，海抜約 1,250 ～1,000 m) に二分される。Ibの北側には，それぞれ海 抜 $900 \mathrm{~m}$ 内外と $800 \mathrm{~m}$ 以下とに頂面をもつ, 高位丘陵 地帯 (IIa) と低位丘陵地带 (IIb) があり，その北は盆 地底に連なる扇状地带（III，海抜約 $750 \mathrm{~m}$ 以下）とな る。IIではIよりも水流が短区間で合流する傾向がみ られる。この範囲に, 次の 10 種の小地形単位が認定さ れる。

[尾根筋]

-丘（山）頂緩斜面（Hilltop gentle slope：Ht）：稜 線部に広がる傾斜 15 度程度以下の緩斜面。安山岩・火 砕岩の深層風化層を母材とする赤色土壌が発達する。

Ia, IIa に広く，IIbにも一部みられる。

・定高稜線 (Accordant ridge：Ar)：稜線の軸方向に は定高性があるが，横断方向には幅が狭い。土袞も概 して薄い。Ia, IIa, IIb で Ht の延長上に位置する。

・一方向に傾き下がる稜線 (Monoclinal ridge : Mr)： Ib に多い。IIa, IIbの Arの先端にもある。

・孤立小丘 (Isolated hillock：Ih)：IIbの Ar から突 出する。基岩の侵食抵抗性により, IIa からの低下が遅 れた。

上記尾根筋の諸類型のうち, Ia, Ib にあるもの以外 は削剝性とみてよい。
[中間帯]

-急崖带 (Scarpland: Sc)：IIa とIIbとの境界抢よ びIIbの前面に位置する。傾斜はしばしば 50 度にも達 し, 土壤はほとんど発達しない。崖の下端に露出する 基岩の割れ目等から湧水がある。

・丘（山）腹斜面（Hillside:Hs）。(略)。

[谷筋]

- 浅開析谷 (Saucer-shaped trough: St) : 浅い皿状 の横断形をもち,下流に向けて細長い平面形を示す。谷 頭部には，しばしば，風化層基底付近に形成されたパ イプがあり，雨季にはそこから流出がある。Ia，IIaに よく発達する。

-小峡谷 (Small gorge : G) : V 字型の横断形 (深さ 数十 $\mathrm{m} \sim 100 \mathrm{~m}$, 谷壁の傾斜 30 度以上）をもち，谷底 に明瞭な水路がある。St の下流側に続くものと, Sc下 部の湧水を受けて谷頭付近からこの型の谷となってい るものとがある。

- 狭長谷底 (Narrow valley-bottom：Nb)：急斜した 谷壁に挟まれ，狭いが平坦な谷底面と明瞭な水路をも つ。IIbで Gの下流側に連なる。

一小扇状地 (Alluvial fan: F)。(略)。

各小地形単位の形態, 性状, 空間的配置の特性から, まずIIaで侵食地形の発達が行われ，基準面の低下 (IIb) 後, 付加された火山 Ia/Ib の開析 (II の水系との 連続）が進み，新たな基準面（III）への適合が現在進 行中と考えられる。この地域では，竹林に戻すことを 含む独特の輪作体系が一部に残存し, sustainable agroforestry の一形態として注目されている。その存 立基盤としての土地条件について, 上記の知見をもと に論じることができよう。

\section{ペルー, ナスカ台地の地上絵と微地形}

\section{阿子島＼cjkstart功（山形大）}

ナスカ地上絵の考古学調査に扔いて, 人工衛星 Quick Bird画像によって地上絵分布図を作成する こと, 同画像の画像処理によって地形分類図を作成す る手法, 地上絵の描き方と台地の表層構成物との関係, ナスカ台地の地形配置などについては先に述べた（阿 子島 2005.3 日本地理学会)。今回は土地条件が作成当 時にどの程度考慮されたのか, あるいは無視されたの か, 微地形分類図によって表現できる地表面の変化速 さ(安定度・不安定度) と地上絵との関係, 微地形と 現在までの地上絵の損傷程度との関係，将来の地上絵
の損傷の見積りなどについて現地観察結果を含めて述 ベる。

1. ナスカ地上絵が描かれたときの土地条件

a）地上絵の地形的位置について

ナスカ台地地域の地上絵は, 台地面より高い丘陵斜面 (フクロウ人間が有名), 台地上面（とくに台地北部に は”核心地域”と呼ばれ，線・帯・図形・図像が集中し ている地区がある), 台地と開析谷底との間の段丘状の 部分と斜面に分布している。今回，新発見の図像 (ニュートン, 2006.7 は, ナスカ台地の南部で, 台地面 
と谷底面との間の波状起伏地にあった。

台地を刻むナスカ川やインへ二オ川に沿った汇濫原 面には地上絵は希薄である。谷底氾濫原面はこの地域 で最も地形変化の激しい（更新されている）部分であ るが，かつて地上絵が描かれ，後に消失したと考えら れる部分もある。すなわち，あらゆる地表面に地上絵 が描かれたといえよう。

とはいえ，平坦面の広がりと図形との関係は，平坦 面のひろがりにあわせてまとまりよくえがかれたた め，図形の方向も平坦面のまとまりに支配されている ことがある。とくに台地緑辺の狭い台地面では，図形 の向きが平坦面の形に支配されている例がある。台地 縁辺の中段の平坦面上の台形は河川の方向のものと直 交方向のものが多いことをアヴェニ（2006, ナスカ地 上絵の謎。田義郎監修, 武井慶利訳, 創元社, p. 249250)が述べているが平坦面の形にあわせた結果である とみることもできる。

b）地上絵と起伏について

動物や植物などの図像は台地北部核心地区のように 起伏が小さく広い平坦面であるところに集中して繰り 返し重福きされている例があるが，今回の新発見の 図像（前述）は，ナスカ台地の南部台地面縁辺の，見 通しが悪い起伏地にあり，ここでは起伏は無視されて いた。

長い線・細い带は，地形起伏にかかわらず，起伏の 障害を超えて一定方向にむかって措かれて抢り，台地 の縁や台地上面のなかの川岸の肩へ下りている例があ る。

台形など図形は平坦部分の広がりを意識して配置さ れた例がある。

c）地上絵と土色抢よび土地表面の安定度・不安定 度について

安定で風化帯がよく保存されている部分は遠望して 暗色であり，河道によって表層物質が更新されている 不安定部分は明色である。人工衛星画像の画像処理で 安定〜不安定の区分図を描くことができる。地上絵は 前者の部分であれば明瞭に描きやすく，残りやすい。
ナスカ台地北東部分では，上面を流れる Majuelos 川を境として，河道跡の密度の高い南東側（1）と，河 道跡のごく少ない北西側（2）との対照が明瞭である。 （1）では河川が山地・丘陵地を後背地としており，深 く長いが，(2) では河川が台地上面から発しているた め浅く短い。山地・丘陵地加ら発した河川は Majuelos 川に注ぐため，それより北西側には及ばない。これに 対応して地上絵・線の分布密度には明瞭な差が認めら れ，(2)では地上絵が多いが（1）では少ない。すなわ ち，（2）では暗褐色に風化した地表が広いために明瞭 な地上絵を描くのに適しているが，(1) ではしばしば 河流が流れることから,地上絵を描いても保存が悪い。 したがって（2）に地上絵が多いという理由は北側のイ ンヘニオ川の緑豊かな谷にそって立地していた遺跡に 近いという理由のみではなく，地上絵を描くにあたつ てナスカ人は土色を意識したものと考えることができ る。

2. 地上絵の損傷の将来見積もりと保全

地上絵は発見されて以来, 篣で掃いて強調された部 分もあるが, 基本的には約 1,500 年間以上の間, 保存さ れてきた。地上絵をつくる線や带が浅い河道跡によっ て切られている部分があるが，さらに1,500 年間を経 ても，その深さが 2 倍になるか，もしくは河道密度が 2 倍になるかのいずれかであろう。おそらく, 河道は固 定的で深さが増すことになると予想される。したがっ て，自然的な原因による地上絵の損傷はそれほど深刻 ではない。むしろ，人為的な改変である自動車の輬に よる直接の損傷やパンアメリカンハイウエイなぞの工 作物の影響が問題である。耕作地の境の石積みやパン アメリカン八イウエイの盛り土が塞き止となって砂泥 が堆積している箇所が多く見受けられる。道路と交差 する河道のトンネル部分では土石流の度に排土が必要 になっている。したがって，台地に砂防ダムや流路工 などの安易な新設はさけるべきである。線や帯は記録 保存で対応し，図像・図形は保存保護を個別に検討す ることになろう。 


\title{
中国内モンゴル自治区武川県における農地のガリー浸食 -2003 年からの観測結果を中心に一
}

\author{
大月 義徳（東北大）・西城＼cjkstart潔（宮城教育大）。 \\ 谷口多聞 (東北大・院) ・中村 美里 (宮城教育大・院)
}

Yoshinori OTSUKI, Kiyoshi SAIJO, Tamon TANIGUCHI and Misato NAKAMURA: Gully Erosion in Agriculutural Lands since 2003, Wûchuān County, Inner Mongolia, China

中国，内モンゴル自治区における荒漠化，あるいは その対応政策のひとつである退耕還林・退耕還草等に 関わる人文・自然地理学的共同研究が 2002 年度より開 始・継続されている。発表者らも，土地環境条件の劣 化および土壤浸食に関わる地形学的調査を分担し，そ の結果の一部は当学会 2003 年度春季大会, 2003 年度 研究集会等で報告している。本発表は，2003 年夏季以 降のガリー壁後退量観測の結果を中心に，近年におけ る土壌浸食状況の報告を目的とする。

調查地域は，大青山山地（黄河中流低地北隣，陰山 山脈の一部）の北側背後，ジュラ系〜新第三系陸成堆 積岩の主要分布地域である武川構造盆地内にある。武 川における年平均気温は $2.5^{\circ} \mathrm{C}$ (武川県誌編纂委員会, 1988 ：おお扔む1 1960 年～1980 年代中盤の平均值と推 察される)，年平均降水量は $354.1 \mathrm{~mm}$ (1970 年〜2000 年，武川県気象局観測値による）とされている。

観測地点は，武川県大豆鋪郷興合玉 (Xīnghéyù) 集 落付近 (地点 1, 大略 $\mathrm{N} 41^{\circ} 13^{\prime}, \mathrm{E} 111^{\circ} 34^{\prime}$ )，および大豆 鋪郷の西隣，安字号郷鵴咀営子 (Jĩzuryíngž̃) 集落付近 （地点 2, 同 $\mathrm{N} 41^{\circ} 08^{\prime}, \mathrm{E} 111^{\circ} 30^{\prime}$ ) にて農地の隣接し発達 するガリーの頭部に位置し，いずれも標高は $1,650 \mathrm{~m}$ 前後である。地点 1 打よび地点 2 におけるガリ一集水 域はそれぞれ約 $0.78 \mathrm{~km}^{2}$ および $0.32 \mathrm{~km}^{2}$, 集水域内の 最大起伏はいずれも約 $30 \mathrm{~m}$ と低起伏である。この調 查地一帯に広がる平坦・低起伏な地形は, 主としてシー トウォッシュ堆積物を切る削剝面の分布によると考え られる点は，以前に報告したとおりである。

両地点のうち地点 1 では, 現地住民からの聞き取り および簡易測量結果から，過去 $50 \sim 60$ 年間程度の平均 ガリ一伸長速度は $1 \mathrm{~m} / \mathrm{yr}+$ 程度と見積もられる（大 月・西城, 2003, 2006)。そこで上記 2 地点において, 2003 年 8 月に定点ピンを設置し，また 2004 年 8 月および 2005 年 8 月にトータルステーションによる測量を行 い，両計測結果よりガリー壁後退量を把握した。これに よれば, 比高約 2〜 $4 \mathrm{~m}$ のガリ一壁が形成されている地 点 1 に㧍いて, 年間後退量の最大值は $0.15 \mathrm{~m}$ （2003-
2004 年) および 0.45 m (2004-2005 年) であった。また 地点 2 (ガリー壁比高約 $5 \mathrm{~m}$ 程度) では, $1.15 \mathrm{~m}$ (20032004 年) 抢よび $0.45 \mathrm{~m}$ （2004-2005 年）であった。

とくに地点 1 ではガリ一端上方の農地に扔いて, シートウォッシュが発生している様子が観察され，ガ リ一頭部付近におけるウォッシュの収束が，ガリ一壁 の新たな崩壞に連動しガリー伸長に直接寄与している 状況が明膫である。このことは, 本地域のガリー浸食 と sheet erosion とが不可分の関係にあることを強く 示している。

現時点における観察・検討結果を，発表者らの既往 の報告結果と関連付けると，以下のようにまとめられ る。

1）ガリー浸食はシートウォッシュの収束によって 発現しており, sheet erosion と強く連動している。

2）本地点に扔けるガリ一伸長速度が，継続的に 1 $\mathrm{m} / \mathrm{yr}$ を上回る (上回っていた) 状態を積極的に想定す るのは，現在のところ難しい。しかし観測期間が短く， 先述した過去数十年の状況を考慮すると，今後，年間 後退量が上記の值を上回る可能性は十分にある。

3） $1 \mathrm{~m} / \mathrm{yr}$ 程度の平均伸長速度を仮定すると, 両地 点のガリー浸食は少なくとも過去数百〜 1,000 年程度 の期間にわたって継続していると考えられ，ガリーの 発生・発達は $3 \mathrm{ka}$ 以降に堆積したシートウォッシュ堆 積物（大月・西城，2003，2006）に対応する可能性があ る。

4）現在のガリー浸食は，近傍河川の河床高度へ適 合するように進行しており，農地はもとより，たとえ ば地点 2 付近の草地に扔いても，現状の植生種や植生 被度では土壤緊縛力が著しく低く，ガリー浸食を含む 流水による浸食作用は当面継続すると考元ら机る。

5）ガリー浸食の強度および発現頻度を低下させる には，地表全体の浸食受容性を低める方策が重要であ り，そこには地域固有の自然環境条件の考慮が不可欠 である点は論を待たない。画一的手段での浸食防止は 容易ではない。 


\section{新潟県川口町で行った中越地震災害調査結果報告会}

2004 年新潟県中越地震の地震被害調査を組織的・重 点的に行った新潟大学・防災科学技術研究所・産業技 術総合研究所の 3 者合同で, 被害地域の中心である川 口町において一般向けの調査結果報告会を行った。

この報告会は，フィールド調査でお世話になった 方々に結果を報告することはごく自然であるという認 識に加え，1）テーマの性質上関心が高いと予想され る，2）防災地学への要望・批判などの意見を直接聞く 機会とすることができる，3）２次災害の恐れがある 地域では特にきめ細かな專門的アドバイスを求める人 がいる可能性がある，という考えから調査担当者が自 発的に企画したものである。

町担当者 (企画商工課) の皆様の意見を聞きながら， 来場者に納得してもらえる会とするよう心がけたが， 家族を失った方の居る町で「震災軽減」を基調とする 報告会を行うことに対して, 内心不安を感じていた。

地元の方との交流を第一に考えたため事前に町内各 位以外にはほとんど告知しなかったが，3月25日（土） 当日には予想を上回る 135 名の方（おそらく大部分は 川口町在住の一般の方, 特に高齢者が多かった）に来 場いただいた。

報告会は，来場者から率直な批判・意見を聞くこと， 相互の信頼関係をつくることを目標として，1）口頭 発表，2）パネル展示(ポスターセッション)，3）懇親 会, の 3 部形式とした。口頭発表の演題・演者は次の 通りである。(1)川口町を襲った地震動の特徵（吉見： 産総研) (2) 中越地震による災害一川口町を中心とし て一(ト部：新潟大) (3) 川口町の地盤の違いによる摇 れやすさ分布について (先名：防災科研) (4)川口町田 麦山地区の地質と建物被害の関係（宮地：産総研）(5)

\section{小松原琢（産業技術総合研究所）}

中越地震による地すべり発生斜面と地すべり地形（井 口: 防災科研) 6 震災の教訓（全員・ただし発表は小 松原: 産総研)。また, パネル展示では, この6 報告に 関する大縮尺地図を使った展示のほかに, 地震や地震 動一般, 地形分類図, 地質図に関する展示・実験を行っ た。

対等な関係で率直に意見交換を行うことを意図し て, 特にパネル展示に力を入れた結果, 土曜の午後 (1 時半〜 5 時）にもかかわらずほぼ来場者全員がパネル 展示終了時まで残ってくださり, 貴重な意見を聞くこ とができた。

アンケートや個人的に話を聞いた結果では，1）地 震予知研究に対する期待，2）被災地に伝わりやすい 災害情報伝達方法の開発，3）調査・研究結果の地元へ の普及，4）危険箇所認定のための基礎的調査と危険 箇所情報の開示，を求める意見が多く聞かれた。また， 地震直後にガスが停止したことによって火災が発生し なかった例を挙げ，阪神地震の教訓が活かされている ことを感じた一方で，今回の震災の教訓をきちんと伝 え，災害軽減に努めて欲しいという意見を聞くことが できた。

この報告会で私が得たことは,「災害研究の成果が社 会に受け入れられるためには…‥」という当初の問題 意識の浅はかさを感じた一方で, 非専門家の一般的な 意見を災害研究の中に取り入れていくことの重要性を 認識したことだったのかもしれない。どのような方向 で今後研究を進めるか，深く考えるきっかけとなった という点で得るものが大きな報告会であったと感じて いる。報告会に多大な協力をくださった川口町企画商 工課の皆様・来場された方々に深く感謝している。

\section{郡山における河川変遷と土地利用変化}

\section{1. 概要}

郡山は福島県南部にあり, 人口約 34 万人の中核都市 である。この街は，古くから交通の要衝であるが，明 治前半まで街自体は小さく，台地上に立地していた。ま た，阿武郎川を渡るには渡し舟によっていた。現在の この街の発展の基礎は明治以後に作られたものであ る。

\section{赤 桐 毅一((株)きもと)}

郡山の発展には，多くの要因があるが，永く交通の 要衝であること，安積疎水，安積開拓の成功，それら が基礎となって工業の発展をもたらしたことが知られ ている。ここでは河川の改修が郡山の発展にどのよう に影響しているか検討した。

2. 方法

(1) 迅測図及び明治 41 年から最新版平成 13 年度ま 
での旧版地図から土地利用別面積を計測し，着色して 市街地拡大の進み方を検討した。米軍〜平成 13 年の空 中写真を援用した。(2) 同じ旧版図や空中写真を用い て河道の変遷を検討した。(3) 現在の河道周辺の地区 を選定して, 人口の変化, 工業生産の変化, 土地利用 面積の変化を比較した。以上の結果から, 河道の変遷 が土地利用の変化に及ぼした影響を検討した。

\section{3. 結果}

明治前半, 郡山市街地は台地上にあり, 以後ゆっく りと郊外に拡大した。一方で明治時代に頻発した阿武 隈川本川の氾濫対策として大正 9 年から昭和 9 年にか けて本川河道が大幅に付け替えられた。これにより,そ れまで河道が乱流して定まらず，困難だった架橋が容 易になり，ほとんどなかった郡山の東の本川をまたぐ 橋が短期間にいくつも建設された。それに従い，道路 が建設され，交通は飛躍的に便利になり，阿武郎山地 丘陵から会津方面までの後背地域を含め, 両岸地域が 一体化して発展する基礎ができた。

その後, 近年の河川整備及び堤内地の低地の埋め立 て, 盛土により河道の近辺に抢ける水害危険度が相対 的に減少しつつあると理解されて，工場，住宅等が大 規模に進出するようになった。

郡山は, 人, 物資の集散地となり, 徐久に街は拡大 してきた。街の拡大を見ると, 河道を固定したことが その後の発展の基礎となった。昭和 40 年代の経済の高 度成長期に低地の埋立てや盛土がなされ, 市街地の拡 大が急速に進み，現在は，拡大した市街地の中を埋め
るように建物と人口が増加し，郊外では年々道路網が 高密度化している。

平成 10 年の水害のあと, 平成の大改修と称して平成 11 年から 2 力年で阿武郎川郡山付近の河道の大改修 が行われ, 治水安全度がさらに向上し, 現在では河道 の周辺であっても市街地（住宅及び工場用地含む）形 成が進んでいる。

旧版図を用いて土地利用面積を計測したところ，道 路, 市街地の面積が非常に増加し, 森林や畑が大幅に 減少している。また，河道沿い地区においては，人口 の増加, 工業生産の増加, 市街地自体の低地への拡大 などが継続的に見られる。既に，阿武隈川本川の河道 の周辺低地は在来の郡山市街地と一連の市街地を形成 している。

\section{4. まとめ}

郡山に扔いては，本川河道は大正 9 年から昭和 9 年 にかけて大規模に付け替元，拡幅及び河道の固定がな され，永久橋架橋が可能になったことがその後の土地 利用，市街地の発展の基礎を作ったと言えここのこと により両岸地域がその後背地を含めて一体化して発展 するようになった。河川整備の郡山の発展への影響に ついては, 従来, 河川の事は地味であるが, 利水では 西の安積疎水・開拓, 治水では東の河川整備といって 良いだけの影響を郡山地域に与えてきた。このように 河川を整備することにより，周辺を含めた地域に大き な影響を永年与えることがわかる。

\section{「地域」の検討課題}

地理学の研究対象は, と問われれば,「地域」と答え る人が大多数を占めるのではないか。その「地域」と いう語は, 地理学の領域に限らず，一般社会の中で普 遍的な語となり社会の各界各層に, あらゆる分野にて, 日常的に使用されているのは周知の通りである。

経済発展により経済社会は規模的に大きくなり，そ れを支える体制は分業化, 専門化を背景に, 縦割体制 で対応し,かつての地緑的共同社会の弱体化もあって， 経済体制も社会構造も企業社会型の色を濃厚にしつつ ある。このため縦割社会から「地域」が使用されてい るためか，広範かつ多義に利用され，また変化も激し くしているように見受けられる。

そこで報告では, 地理学存立の根底ともなるだけに， 一度改めて地域を取り上げ，学会に扔いて討議する価

\section{今 野 修 平 (国土計画協会)}

值がある議題ではないかと考え, 個人としては限界が あるのを承知で，問題提起を試みるものである。

「地域」が広く普遍的に使用されているが，その定義 は国語辞典等と地理学関係の辞典ではニュアンスが異 なっている。地理学関係の定義でも, 70 年間前の辞典 では等質地域を指す定義となっており, 地域の概念が 時間の流れで変化していることを伺わせる。また一般 社会が日常使用している辞典と地理学辞典とでギャッ プがあるとすると問題は根深い。

「地域」が広範かつ多義の利用を知るため, 反対語を 探してしてみると感覚的ではあるが，10 種類近くあ る。並べてみて感じることは, 近代日本形成以後の国 土の形成や中央集権型行政等主流的動向に反対する意 味合いで利用されていることが多い。特に地方とは同 
意義的に利用されているように思える。

またこの背景に自然発生的社会とか歳月を経ての慣 れ等の体質を有している共通性があると思えるが，有 機的結合体としての空間だといえようか。

この「地域」形成に大きな力となったのは，近代日 本では経済発展であろうか。特に石油危機以降の高度 技術型工業化と交流経済化の進展は, 結節地域化が進 展しており，拠点都市化や工業や農業生産地域の衰退
化と同一傾向上にあるのではないか。また最近では,グ ローバル化の中で, 地球社会に対しアジア地域等と国 際的広域的に使われることが多い。

こうした動きがみえる中で，国の行政改革では道州 制も見据えて新しい地域区分が検討されている。これ に対し地域を専門領域とする地理学はどう受止め，討 議しているのであろうか。不可欠かつ緊急な課題とし て，日本列島の空間を見直すことを問題提起する。 